\title{
Measuring the concept of "wellbeing": A first approach for Bolivia
}

\author{
Jose Antonio Canaviri
}

\begin{abstract}
This is a first approach to measuring wellbeing in Bolivia at subnational levels. The analysis includes the construction of a multidimensional index that calculates "distances" (Distance P2). The index considers the worst values of a set of indicators taken as a reference among municipalities (unit of analysis) and aggregates across time (from 2000 to 2011) and dimensions (material, social and human). The comparisons are of changes over time between municipalities, based on their wellbeing values. It aims to answer the following questions:

- What is the level of wellbeing of the Bolivian population from an objective-subnational perspective?

- Which municipalities have the highest and lowest levels of wellbeing?

- How has the wellbeing of the Bolivian population evolved over time at subnational levels?

- Which indicators contribute most to the measurement of wellbeing at subnational levels?

In general, the municipalities with the lowest values of wellbeing are concentrated in the Department of Oruro. In addition, if temporal analysis is included, these municipalities remain in the lowest positions. Overall, Bolivians' wellbeing decreased at subnational levels over time from 2000 to 2011.
\end{abstract}

Keywords: wellbeing, subnational, distance $\mathrm{P}_{2}$, dimensions, multidimensional

\section{Introduction}

During the Bolivian president Evo Morales' administration, the Ministry of Development and Planning (2006) had developed a National Social and Economic Development Plan (NDP) for Wellbeing. The NDP was officially launched in 2006, and its main strategic guidelines aimed at the transformation of Bolivia to embrace the "wellbeing" concept, involving criteria such as life satisfaction and/or quality of life in a broad sense. Although the concept of life satisfaction became a strategic part of the public policy agenda of the Bolivian Government in the first period of Morales' governance, no attempts were made to measure it.

There is substantial evidence about measuring wellbeing in the literature and many of the studies focus on criteria for subjective and objective methods. Subjective wellbeing is commonly discussed in the psychology literature in terms of happiness, quality of life, and life satisfaction, although these constructs vary somewhat in definition (Seligson, Huebner, \& Valois, 2005). Subjective measures of wellbeing (cognitive and affective aspects of wellbeing) mention that personal relations are the most important contributor to wellbeing, followed by work, leisure activities and interpersonal interactions, in that order (Nieboer, Lindenberg, Boomsma, \& Bruggen, 2005). The subjective criteria are usually displayed as qualitative information, while objective criteria are exposed as quantitative information, including measuring GDP, GDP per 
capita, (Torras, 2008) and social indicators (e.g., net enrollment rate for primary education, child mortality, expectancy of life, poverty rates and others) (Alkire, 2011; Berenger \& VerdierCouchane, 2007; United Nations Development Programme, 2013).

This study intends to bring an approximation of measurement to the concept of "development and progress," translated - and under the assumption that the wellbeing concept is an appropriate approach to the former - into the NDP of Bolivia. The study uses information gathered before (2000-2005) and during Morales' first period of governance (2006-2010). The results of this study will provide inputs for public policy guidelines in order to identify which dimensions (e.g., material, social, human) and/or sectors (e.g., health, education) need more attention in terms of improving wellbeing, since currently there is no evidence about Bolivians' wellbeing. Given the fact that subnational information in Bolivia is scarce, the results will provide evidence and allow the government and decision makers to consider wellbeing issues from an objective and quantitative point of view, focusing on areas with low wellbeing (cities and municipalities).

The analysis includes the construction of a multidimensional index that calculates "distances" (Distance $\mathrm{P}_{2}$ ), considering the worst values of a set of indicators taken as a reference among municipalities (unit of analysis) and aggregates across time (from 2000 to 2011) and dimensions (material, social and human). The multidimensional composite index at subnational levels will allow for an easy interpretation of the values, will facilitate the task of ranking municipalities according to their wellbeing values, and will reduce the size of the set of indicators to one single summary value.

The analysis includes the comparison of changes over time among municipalities, based on their wellbeing values, and aims to answer the following questions:

- What is the level of wellbeing of the Bolivian population from an objective-subnational perspective?

- Which municipalities have the highest and lowest levels of wellbeing?

- How has the wellbeing of the Bolivian population evolved over time at subnational levels?

- Which indicators contribute most to wellbeing at subnational levels?

In general, the municipalities with the lowest values of wellbeing are concentrated in the Department of Oruro. In addition, if temporal analysis is included, these municipalities remain in the lowest positions. Overall, Bolivians' wellbeing decreased at subnational levels over time from 2000 to 2011.

The study is structured in the following way. Section 2 provides the main objective and a review of literature on wellbeing; section 3 describes the method, domains and data; section 4 presents the main results; and section 5 describes policy implications and conclusions.

\section{Review of Literature}

Using a composite index or synthetic indicator has advantages and disadvantages that may be taken into account. For instance, a composite indicator should ideally measure multidimensional concepts which may not be captured by a single indicator, such as competitiveness, industrialization, sustainability, wellbeing, development and progress, single market integration or knowledge-based society. (OECD, 2008). Even though the main virtue of composite indexes is their usefulness for policy analysis (Nardo \& Saisana, 2008) and their multidimensional approach (Booysen, 2002), if they are poorly constructed or misinterpreted, they may send erroneous messages and may be dangerous for policy making. The multidimensional indices are useful in 
order to compare (e.g., via a benchmark) different countries, cities or municipalities, aggregating various indicators based on a framework.

In this sense, it is important to consider a theoretical framework which sustains and provides the basis for the selection and combination of variables into a meaningful measure (OECD, 2008; Booysen, 2002).

The interest in and the number of multidimensional and composite indexes has increased over the years. For instance, according to the OECD (2008), currently there are more than 160 composite indexes. The multidimensionality of composite indexes covers a wide spectrum of dimensions (see Booysen, 2002 for a detailed list of dimensions). Probably one of the best known composite indexes is the Human Development Index (HDI) by the UNDP (2013). The HDI was launched in 1990 and since then has been produced annually in order to compare countries relative to their development, according to the HDI values. The new version (2013) of the HDI considers three variables for estimation, namely, gross national income, years of schooling, and life expectancy. Another relatively well known index is the Multidimensional Poverty Index (MPI) by Alkire (2011). For the MPI estimation 10 components are chosen; two for health (malnutrition, and child mortality), two for education (years of schooling and school enrolment), and six for living standards (including both access to services and proxies for household wealth). As with the HDI, the MPI compiles information over three dimensions: education, health, and living standards (Ravallion, 2010).

A useful and recently redeveloped composite index is the method Distance $\mathrm{P}_{2}\left(\mathrm{DP}_{2}\right)$. It was initially developed by Pena (1977) and then exploited by Somarriba (2008), Somarriba and Pena (2009), Zarzosa (2009), Cuenca et al. (2010) and Rodriguez (2010). This approach takes as reference a location (e.g., country) and calculates distances from this "reference" point to compare other locations. Zarzosa and Somarriba (2013) use the $\mathrm{DP}_{2}$ method when measuring social welfare in Spain at subnational (provincial) levels. The index uses information on different social indicators (e.g., literacy rate, unemployment, contribution pensions) from various life domains (e.g., health, education, work, social protection), aggregating them into a single summary index. According to the authors, this method fulfils the requirements for a composite index, such as existence and determination, monotony, uniqueness quantification, invariance, homogeneity, transitivity, exhaustiveness, additivity, invariance, conformity and nonarbitrariness in the importance attached to a single indicator. According to them, the main advantage of this approach is that "redundant" information from each single indicator, used to construct the composite index, is removed, and only the relevant information is included. Another application of $\mathrm{DP}_{2}$ by Somarriba and Pena (2009) is applied when they measure quality of life in Europe. They compare the advantages and disadvantages of two approaches similar to $\mathrm{DP}_{2}$ - Principal Components and Data Envelopment Analysis - and conclude that $\mathrm{DP}_{2}$ is the optimal method for obtaining composite indexes for wellbeing. There are other applications beyond wellbeing such as that of Cuenca et al. (2010), who used $\mathrm{DP}_{2}$ as a "new" proposal for the measurement of development applied to the Pacific countries of the African, Caribbean and Pacific Group (ACP); and Rodriguez (2010) presented a "new composite index" of child health in the Least Developed Countries of Africa.

To our best knowledge, there are only a couple of studies that have aimed to measure wellbeing in Bolivia. The first one is the Municipal Development Index for Children and Adolescents (IDINA), which used a composite index at subnational (municipal) level for health, education, social protection, habitability and economic capacity of household indicators. All the indicators were classified per age group (infants 0-5, children 6-13 and adolescents 14-17). Due to the difficulty of obtaining the information required for indicators - and especially because the 
frequency of collection of information at the municipal level is scarce - the indicators were basically elaborated as a mix of sources and years (Economic and Social Policy Analysis Bureau (UDAPE) \& UNICEF , 2005 \& 2008). IDINA index values range from 0 to 1,0 indicating that in a certain municipality children's rights are nonexistent, and 1 reflecting that children's rights are achieved completely, within the scope that children's rights are related to access to health, education, water and sanitation, all of which are considered as a protective environment. The second study is at the departmental level (one above municipal), based on a Quality of Life index. The authors (Ocampo \& Foronda, 2007), use household survey data based on the household's characteristics. Using Principal Components Analysis, their main finding is that urban areas have better quality of life than do rural areas.

\section{A multidimensional index for wellbeing in Bolivia}

According to the OECD (2008) and Nardo and Saisana (2008), there are stages that are required to construct composite indexes. A theoretical framework is required, providing the basis for the selection and combination of single variables and indicators into a composite indicator. When selecting data or variables for the composite index, they should be chosen on the basis of their analytical soundness, measurability, country coverage, relevance and relationship with the phenomena under study (Booysen, 2002). Imputation of missing data is necessary to examine extreme values, since they may become unintended benchmarks. A multivariate analysis is useful in order to investigate the overall nature, structure and properties of the data and indicators, to assess the suitability of the data and to explain the methodological choices such as weighting and aggregation. Normalization is applied to the values of the composite index in order to be comparable and to take account of extreme values. Weighting and aggregation are applied to the indicators after considering the theoretical framework and possible correlation and compensability issues among indicators. It is desirable to carry out robustness and sensitivity analysis of the composite index in terms of the steps described before. Finally, the composite index should be transparent and able to be decomposed into its underlying indicators or values; if possible it should be linked to other variables or other published indicators, and the way it is presented should be clear in order to avoid misleading interpretations.

\subsection{Theoretical framework: Domains}

There is no formal agreement about which domains, even less, indicators, should be incorporated when analyzing wellbeing. For instance, for the Human Development Index, UNDP (2013) uses three dimensions: health, education, and living standards. The same applies to the Multidimensional Poverty Index by Alkire (2011). Various authors have suggested the following domains:

Stiglitz, Sen, E Fitoussi (2009): Material living standards (income, consumption and wealth); health; education; personal activities including work; political voice and governance; social connections and relationships; environment (present and future conditions); and insecurity.

Somarriba \& Pena (2009): Education, health, safety, satisfaction and happiness.

Epley (2008): Crime, health, employment, education and recreation.

Heshmati (2008): Material wellbeing, health and safety, educational wellbeing, peer and family relationships, behaviors and risks, and subjective wellbeing. 
Ocampo \& Foronda (2007): Household characteristics (infrastructure, access to basic services) and their surroundings (crime and security, health, environment, education infrastructure).

Murias, Martinez, \& De Miguel (2006): Consumption capacity, wealth stocks, inequality and economic insecurity.

White (2009): Material considerations (assets, welfare and standard of living); social considerations (social relations, access to public goods, attitudes to life and personal relationships); and human considerations (people's perception of their (material, social and human) positions, cultural values, ideologies and beliefs).

According to White (2009) the three dimensions (material, social and human) are associated with each other and none can exist without the others. Thus, it is important not to forget their unity when analyzing and measuring wellbeing. Another way to think about this is that for any element within people's wellbeing there are potentially three aspects to be considered: what people have or do not have (material); what people do or cannot do with it (social); what people think or feel (human). White also argues for a subjective element for each of the dimensions; however, given the lack of data for the subjective variables, these are not considered here. This approach is used for the study, and the main reason for that relates to the concept of progress and development mentioned in the NDP of Bolivia, and on the nature of data for Bolivia available at the subnational level (see Table 1 below).

Some considerations are important to bear in mind. First, when selecting the indicators (see Table 1 below) for the social dimension, the main criterion was to have a common infrastructure or place where people can interact with each other. In addition, for the material dimension, the number of personnel in health centers, hospitals, schools, colleges and institutes is used as a proxy for the availability of services in municipalities. Second, the classification of the indicators is indicative, in the sense that another indicator may also apply; however, given the lack of information at the municipal level in Bolivia, these dimensions and indicators are used for the analysis. Moreover, aggregating the indicators according to the dimensions does not affect the validity of the results or the estimation of wellbeing. In other words, the focus and relevance is centered in the set of indicators beyond the classification per se. A similar approach is applied in Pena (1977), Somarriba (2008), Somarriba and Pena (2009), and Zarzosa and Somarriba (2013). 
Table 1a. Indicators, descriptive statistics and timeframe

\begin{tabular}{|c|c|c|c|c|c|c|c|c|c|c|c|c|c|c|c|c|c|c|c|c|}
\hline \multirow{2}{*}{ Indicators (unit) } & \multirow{2}{*}{ Dimension } & \multicolumn{4}{|c|}{ Descriptive Statistics } & \multicolumn{14}{|c|}{ Timeframe of Data (from 1992 to 2011)* } & \multirow{2}{*}{$\begin{array}{l}\text { Missing } \\
\text { Data }(\%\end{array}$} \\
\hline & & Mean & SD & Min & Max & 92 & 99 & 00 & 01 & 02 & 03 & 04 & 05 & 06 & 07 & 08 & 09 & 10 & 11 & \\
\hline Extreme poverty (percentage) & Material & 64.1 & 20.8 & 7.8 & 99.6 & & & & $\checkmark$ & & & & & & & & & & & 0.0 \\
\hline Coverage of water (percentage) & Material & 52.4 & 23.0 & 0.6 & 96.7 & $\checkmark$ & & & $\checkmark$ & & & & & & & & & & & 0.0 \\
\hline Coverage of sanitation (percentage) & Material & 28.7 & 18.4 & 0.7 & 80.6 & $\checkmark$ & & & $\checkmark$ & & & & & & & & & & & 0.0 \\
\hline Infant mortality rate (per 1,000 births) & Human & 77.5 & 21.9 & 38.0 & 170.4 & $\checkmark$ & & & $\checkmark$ & & & & & & & & & & & 4.0 \\
\hline $\begin{array}{l}\text { Immunization vaccines for children } \\
\text { (percentage) a) }^{\text {a }}\end{array}$ & Human & 77.3 & 19.6 & 0.0 & 100.0 & & & & & $\checkmark$ & $\checkmark$ & $\checkmark$ & $\checkmark$ & $\checkmark$ & $\checkmark$ & $\checkmark$ & $\checkmark$ & $\checkmark$ & $\checkmark$ & 1.7 \\
\hline Institutional deliveries (percentage) & Human & 53.7 & 24.2 & 0.0 & 100.0 & & & & & $\checkmark$ & $\checkmark$ & $\checkmark$ & $\checkmark$ & $\checkmark$ & $\checkmark$ & $\checkmark$ & $\checkmark$ & $\checkmark$ & $\checkmark$ & 1.5 \\
\hline Children with diarrhoea (percentage) b) & Human & 33.3 & 18.3 & 0.0 & 100.0 & & & $\checkmark$ & $\checkmark$ & $\checkmark$ & $\checkmark$ & $\checkmark$ & $\checkmark$ & $\checkmark$ & $\checkmark$ & $\checkmark$ & $\checkmark$ & & & 0.0 \\
\hline $\begin{array}{l}\text { Children with suspected pneumonia } \\
\text { (percentage) }{ }^{\text {b) }}\end{array}$ & Human & 47.4 & 24.1 & 0.5 & 100.0 & & & $\checkmark$ & $\checkmark$ & $\checkmark$ & $\checkmark$ & $\checkmark$ & $\checkmark$ & $\checkmark$ & $\checkmark$ & $\checkmark$ & $\checkmark$ & & & 0.0 \\
\hline $\begin{array}{l}\text { Net enrolment rate pre-primary } \\
\text { (percentage) }\end{array}$ & Human & 31.1 & 20.3 & 0.0 & 100.0 & & & $\checkmark$ & $\checkmark$ & $\checkmark$ & $\checkmark$ & $\checkmark$ & $\checkmark$ & $\checkmark$ & $\checkmark$ & $\checkmark$ & $\checkmark$ & $\checkmark$ & & 0.8 \\
\hline $\begin{array}{l}\text { Net enrolment rate primary } \\
\text { (percentage) }\end{array}$ & Human & 82.6 & 18.9 & 0.0 & 100.0 & & & $\checkmark$ & $\checkmark$ & $\checkmark$ & $\checkmark$ & $\checkmark$ & $\checkmark$ & $\checkmark$ & $\checkmark$ & $\checkmark$ & $\checkmark$ & $\checkmark$ & & 1.7 \\
\hline $\begin{array}{l}\text { Net enrolment rate secondary } \\
\text { (percentage) }\end{array}$ & Human & 38.5 & 21.2 & 0.0 & 100.0 & & & $\checkmark$ & $\checkmark$ & $\checkmark$ & $\checkmark$ & $\checkmark$ & $\checkmark$ & $\checkmark$ & $\checkmark$ & $\checkmark$ & $\checkmark$ & $\checkmark$ & & 1.5 \\
\hline $\begin{array}{l}\text { Completion rate primary level } \\
\text { (percentage) }\end{array}$ & Human & 63.4 & 24.1 & 0.0 & 100.0 & & & & $\checkmark$ & $\checkmark$ & $\checkmark$ & $\checkmark$ & $\checkmark$ & $\checkmark$ & $\checkmark$ & $\checkmark$ & $\checkmark$ & $\checkmark$ & & 1.5 \\
\hline $\begin{array}{l}\text { Drop out school rate pre-primary } \\
\text { (percentage) }\end{array}$ & Human & 8.8 & 7.1 & 0.0 & 64.3 & & $\checkmark$ & $\checkmark$ & $\checkmark$ & $\checkmark$ & $\checkmark$ & $\checkmark$ & $\checkmark$ & $\checkmark$ & $\checkmark$ & $\checkmark$ & & & & 2.5 \\
\hline $\begin{array}{l}\text { Drop out school rate primary } \\
\text { (percentage) }\end{array}$ & Human & 6.4 & 3.7 & 0.0 & 39.7 & & $\checkmark$ & $\checkmark$ & $\checkmark$ & $\checkmark$ & $\checkmark$ & $\checkmark$ & $\checkmark$ & $\checkmark$ & $\checkmark$ & $\checkmark$ & & & & 2.8 \\
\hline $\begin{array}{l}\text { Drop out school rate secondary } \\
\text { (percentage) }\end{array}$ & Human & 9.1 & 5.8 & 0.0 & 60.0 & & $\checkmark$ & $\checkmark$ & $\checkmark$ & $\checkmark$ & $\checkmark$ & $\checkmark$ & $\checkmark$ & $\checkmark$ & $\checkmark$ & $\checkmark$ & & & & 2.8 \\
\hline $\begin{array}{l}\text { Social investment MDG Poverty (per } \\
\text { capita USD) }\end{array}$ & Material & 2.0 & 5.4 & 0.0 & 144.6 & & & $\checkmark$ & $\checkmark$ & $\checkmark$ & $\checkmark$ & $\checkmark$ & $\checkmark$ & $\checkmark$ & $\checkmark$ & & & & & 27.3 \\
\hline
\end{tabular}


Table 1b. Indicators, descriptive statistics and timeframe

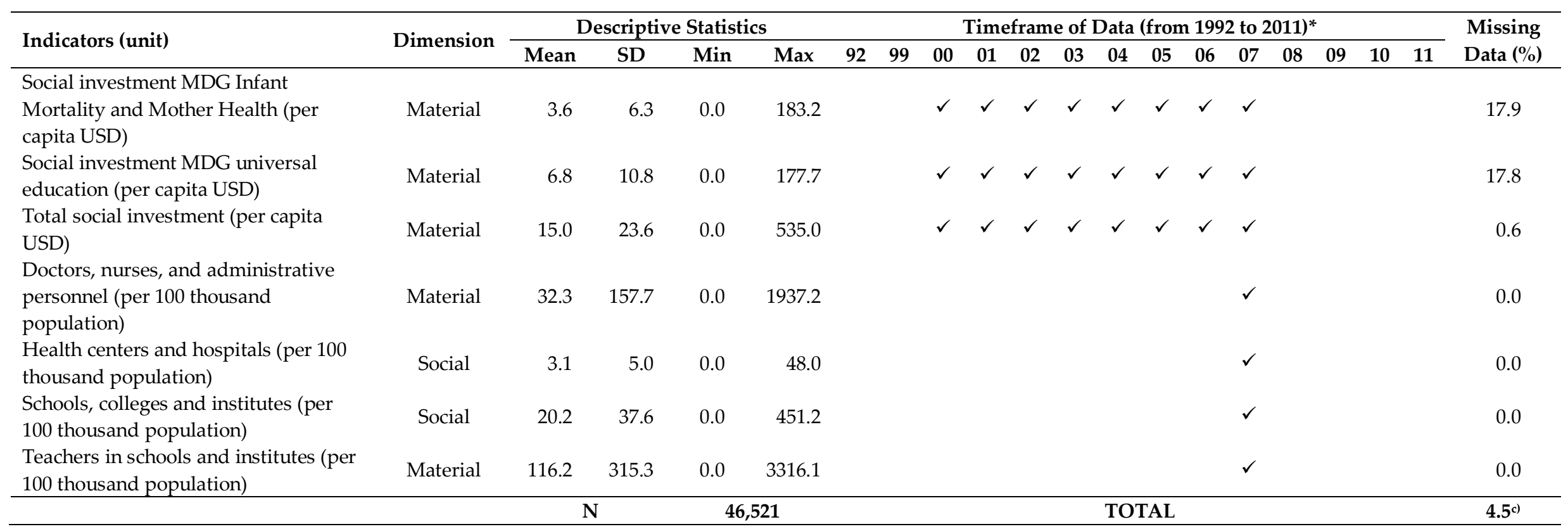

* National censuses carried out in 1992 and 2001

a) For children under 5 years old

b) Children with diarrhoea and suspected pneumonia in the last three weeks before the information was taken and that have been treated for these illnesses

c) Please see Appendix 1 for the imputation method. 


\subsection{Data}

The database contains variables at the subnational level (327 municipalities) from 1992 to $2011^{1}$ classified by the Millennium Development Goals (MDGs) elaborated by UDAPE of the Bolivian Ministry of Planning. UDAPE uses this information in order to track the progress of the MDGs in Bolivia. In addition, there are a few variables used in the analysis estimated by UNICEF Bolivia.

Information at subnational levels is scarce in Bolivia, thus information on these indicators is not regularly available for all years. The systems of information in Bolivia lack data reliability in terms of designing, collecting and assuring the quality of indicators, especially at subnational levels. Another problem is related to the availability of the data. Generally, data are available with two or more years of delay, impeding the chance of generating updated evidence. Information on the indicators' descriptive statistics, their years of availability, the dimension to which they belong, and the percentage of missing data is provided in Table 1 above.

\subsection{Commonly used methods for aggregation and weighting}

There are different approaches to aggregating indicators to construct a composite index by means of linear and non-linear techniques (Nardo \& Saisana, 2008). Pena proposes a method for aggregation based on "distances" ( $\left.\mathrm{DP}_{2}\right)$. The distances are estimated by considering two countries or locations, taking one as a reference point, and the resulting value is divided by the standard deviation. Thus, variables are expressed in abstract units beyond the initial units of the single indicators, allowing the single indicators to be aggregated into a composite index (Somarriba, 2008). Therefore, the latter value is acting as a weight resolving two issues: the units of measurement and the weighting assigned to each observable variable in the composite index (Rodriguez, 2010). In addition, Pena (2009) proposes a "correction factor" which eliminates redundant information and keeps only the "new" information contributed by each single indicator. This correction factor also acts as a weight of the partial indicators. The method $\mathrm{DP}_{2}$ allows for the aggregation of variables expressed in different measures, avoiding arbitrary weights and duplication of information.

The Human Development Index uses the geometric mean as an aggregation method, using three indicators: gross national income, years of schooling, and life expectancy. Using the latter method (in which indicators are multiplied and weights appear as exponents) is appropriate when the individual indicators appear in different scales. However, with this method, countries with higher scores are rewarded more and vice versa (Nardo \& Saisana, 2008). Ravallion (2012) suggests that this method of aggregation may undermine the estimations by the HDI. For instance, variables such as longevity may have been substantially devalued in poor countries and valuations of extra schooling have risen four times higher than the valuations typically placed by the labor market on extra schooling. Thus, when using geometric aggregation, a country with low scores on one indicator will need a much higher score on the others to improve its situation (OECD, 2008).

Related to aggregation, there are implicit or explicit weights when constructing composite indexes. Generally, data comes in different units; therefore, the analyst should use a weighting model to aggregate the information. There are a number of techniques from statistical models used for this purpose, such as factor analysis, data envelopment analysis and unobserved component models (OECD, 2008). The weighting approach will depend ultimately on the analyst, derived from

${ }^{1}$ This range of time is not the same for each variable in the database, as detailed in Table 1 above. 
consultation with experts, or may reflect policy priorities or theoretical factors. Booysen (2002) suggests that equal weighting should be the norm, given the fact that different weighting approaches lead to different results, and given that the subjectivity inherent in many of these weighting systems means all of them are subject to criticism.

Finally, it is important to bear in mind that no method is perfect, as detailed by the OECD (2008, p. 33): "[T] he absence of an 'objective' way to determine weights and aggregation methods does not necessarily lead to rejection of the validity of composite indicators, as long as the entire process is transparent."

\subsection{The Distance P2 method}

This section is based on Pena (2009), who describes the distance method using many indicators to construct a composite index. This method is based on "distances," in absolute or quadratic terms, between each indicator from different locations or in relation to a reference value. Let $X=\left\{x_{i j}\right\}$ be the data matrix for $m$ unities (rows), in this case the municipalities, and the $n$ indicators (columns), in this case the proposed indicators for wellbeing. Let $X_{j}$ be the vector of the components in the status $j(j=1, \ldots, m)$, which may refer to a period of time or unit:

$X_{j}=\left[x_{j 1}, x_{j 2}, \ldots, x_{j i}, \ldots, x_{j n}\right]$, where $x_{j i}$ is the status for the $i$ component in the status $j$ where $(i=1,2, \ldots, n$ and $j=1,2, \ldots, n)$. The reference group is defined by $X_{*}=$ $\left[x_{* 1}, x_{* 2}, \ldots, x_{* n}\right]$.

As regards the $n$ components, the $p$-metric distance is defined as:

$$
D_{p}=\left\{\sum_{i}\left|x_{j i}-x_{* i}\right|^{p}\right\}^{\frac{1}{p}}
$$

The quadratic case will be when $p=2$, and the simple distance case when $p=1$. The Frechet distance (DF) (as cited in Pena, 2009) is defined as:

$$
F(r, k)=\sum_{i} \frac{d_{i}(r, k)}{\sigma_{i}}
$$

where $d_{i}(r, k)=x_{r i}-x_{k i}$ and $\sigma_{i}$ is the standard deviation of the values considering the $i$-value. From the Frechet distance the Ivanovic-distance (1963) is defined as:

$$
D I(r, k)=\sum_{i=1}^{n} \frac{\left|d_{i}(r, k)\right|}{\sigma_{i}} \prod_{j=1}^{i=1}\left(1-r_{j i .1,2, \ldots, j-1}\right)
$$

where the factor $\prod_{j=1}^{i=1}\left(1-r_{j i .1,2, \ldots, j-1}\right)$ is added to the DF distance function, which is 1 minus the product between the $i$ and $j$ coefficients correlation, where $(j>i)$. This factor is introduced to take into account the duplicated information by measuring the $r_{j i}$ coefficient and the degree of association between the new indicator introduced and that immediately above, once eliminated in both effects of all other included indicators.

Pena (2009) proposes the following $D P_{2}$ solution in order to eliminate redundant information by means of the correction factor:

$$
D P_{2}=\sum_{i=1}^{m} \frac{d_{i}}{\sigma_{i}}\left(1-R_{i . i-1, i-2, \ldots, 1}^{2}\right) \text { with } R_{1}^{2}=0
$$

Where $d_{i}$ and $\sigma_{i}$ are the same as the DF indicators, the "correction factor" $\left(1-R_{i . i-1, i-2, \ldots, 1}^{2}\right)$ aims to suppress unnecessary information. Suppose that the components are ranked by the iterative method described earlier in the following order: $x_{1}, x_{2}, \ldots, x_{n}$. Assuming that $x_{2}$ has a linear dependence on 
$x_{1}$, then the coefficient of determination in the regression of $x_{2}$ on $x_{1}$ gives the total variance in $x_{2}$ explained by the regression. Thus $1-R_{21}^{2}$ is the $x$ unexplained variance by the linear action of $x_{1}$. $1-R_{21}^{2}$ can then serve as a correction factor for component $x_{2}$, since the part of the variance explained by the linear dependence is eliminated on the contribution made from this indicator to the $D P_{2}$. Similarly, if the synthetic indicator has considered components $x_{1}$ and $x_{2}$ and we want to introduce a new component $-x_{3}$ - linearly dependent on the above, the correction factor is $1-R_{3.2,1}^{2}$; that is, the complement of the coefficient of determination in the regression of $x_{3}$ on $x_{2}$ and $x_{1} . D P_{2}$ enjoys all the properties required of a good distance indicator and also allows for inter-temporal comparisons to compare identical territorial units in various time periods. For a detailed and comprehensive explanation, see Pena (1977), Somarriba and Pena (2009) and Somarriba (2008).

In order to apply $\mathrm{DP}_{2}$, a municipality that has the worst value is taken as a "reference."' Thus, $\mathrm{DP}_{2}$ will estimate the "distance" of each municipality with regards to this "reference" municipality. A lower $\mathrm{DP}_{2}$ value will be indicative that the value is closer to that "reference" or worst wellbeing value. In other words, higher $\mathrm{DP}_{2}$ values will reflect higher wellbeing for a given municipality. To guarantee the fulfillment of the properties of $\mathrm{DP}_{2}$, certain variables whose increase implies a worsening of wellbeing were multiplied by -1 , so that an increase in the value of any variable might mean an improvement in the quality of life. For instance, the extreme poverty indicator ideal value will be the one that is low (it is better to have fewer poor people in a given municipality), thus, a low value for the indicator is preferred instead of a high value. However, a high value is also desired for other types of indicators. For example, it is better to have a high rate of net enrolment in the municipality than to have a low one.

\section{Results ${ }^{2}$}

Given the nature of the data (Table 1 above), mainly because of temporality, the analysis is carried out at three stages. The first stage examines the comprehensive encompassing indicators from 2000 to 2011. The second captures the period before Morales' first period of government, which is the years 2000 to 2005. Finally, indicators from the first period of Morales' government, from 2006 to 2011, are examined. The years from 1992 to 1999 are not considered, since only three indicators are available and the gap from 1992 to 2000 is large.

Following Somarriba and Pena (2009) and Somarriba (2008) to estimate the wellbeing indicator (WBI), there are stages for these estimations. The first stage estimates WBI values for those variables which have more than one year of information (see Table 1 above). For instance, immunization vaccines for children has information for 11 years; thus, in the first stage, the WBI estimation was made considering these 11 years. The second stage required estimation of WBI values (from the first stage) of variables which were not included in the first stage (e.g., those variables which only had one year of information, such as health centers and hospitals) in order to estimate the WBI values for each dimension (material, social and human). Finally, in the third stage, the WBI values for each dimension were used to estimate the total WBI values at subnational levels.

${ }^{2}$ All the analysis is carried out in MATLAB using the code kindly provided by Noelia Somarriba. 


\subsection{The period 2000-20113}

\subsubsection{Correction factors}

The coefficient of the linear correlation value $|r|$ between each indicator and the wellbeing value is estimated below, as is the correction factor $\left(1-R_{i . i-1, i-2, \ldots, 1}^{2}\right)$ from equation (4), indicating how much each indicator contributes to the WBI. Table 2 below shows these values:

Table 2. Ranking of the variables according to order of entrance in the DP2 and correction factors

\begin{tabular}{lcc}
\hline Indicator [Domain] & $|\boldsymbol{r}|$ & $\mathbf{1}-\boldsymbol{R}^{\mathbf{2}}$ \\
\hline Immunization vaccines for children [H] & 0.6295 & 1.0000 \\
Net enrolment rate primary [H] & 0.5785 & 0.1129 \\
Extreme poverty [M] & 0.5430 & 0.0970 \\
Total social investment [M] & 0.5315 & 0.1057 \\
Health centers and hospitals [S] & 0.5303 & 0.8974 \\
Institutional deliveries [H] & 0.5050 & 0.4471 \\
Social investment MDG universal education [M] & 0.4972 & 0.7658 \\
Social investment MDG infant mortality and mother health [M] & 0.4777 & 0.6298 \\
Teachers in schools and institutes [M] & 0.4714 & 0.8831 \\
Schools, colleges and institutes [S] & 0.4702 & 0.7264 \\
Doctors, nurses, and administrative personnel [M] & 0.4623 & 0.3246 \\
Net enrolment rate pre-primary [H] & 0.4449 & 0.4858 \\
Completion rate primary level [H] & 0.4421 & 0.6661 \\
Coverage of sanitation [M] & 0.4245 & 0.6734 \\
Social investment MDG poverty [M] & 0.3937 & 0.1879 \\
Net enrolment rate secondary [H] & 0.3653 & 0.7219 \\
Coverage of water [M] & 0.3366 & 0.5787 \\
Children with suspected pneumonia [H] & 0.3294 & 0.7251 \\
Children with diarrhoea [H] & 0.2955 & 0.1995 \\
Infant mortality rate [H] & 0.1897 & 0.5753 \\
Drop out school rate pre-primary [H] & 0.1801 & 0.8893 \\
Drop out school rate secondary [H] & 0.1244 & 0.8192 \\
Drop out school rate primary [H] & 0.0180 & 0.5816 \\
\hline
\end{tabular}

The ranking shows the order of the variables included in the analysis in accordance with their order of entrance; that is, according to their coefficient of linear correlation between the values of the indicator for each municipality and the WBI. Immunization vaccines for children retains all its information (100\%), whereas drop out school rate primary has the lowest value of correlation, retaining only $58.1 \%$. It is worth mentioning that the indicators for the Social Dimension (number of health centers and hospitals per 100,000 population and number of schools, colleges and institutes per 100,000 population) retain almost $90 \%$ and $73 \%$ respectively ${ }^{4}$.

\footnotetext{
3 The results described below are based on the single indicators detailed in Table 1 above, for which information is available from 2000 to 2011.

${ }^{4}$ Access to these services is vital for any group of people, given that most of the Bolivian population is considered poor; however, the extreme poverty variable only contributes $\sim 10 \%$ but is highly correlated $(r=54.3)$ with the WBI estimation.
} 


\subsubsection{WBI results}

Once the WBI for each municipality $(n=327)$ was obtained, all the values were normalized for a better interpretation, since the values obtained vary for each dimension and are not directly comparable. The values were normalized using the following formula ${ }^{5}$ :

$$
W B I S_{j}=\frac{x_{j}-x_{\min }}{x_{\max }-x_{\min }}
$$

where $W B I S_{j}$ is the standardized value of the WBI composite index for the $j$ indicator

$x_{j}$ is the WBI value without being standardized

$x_{\max }$ is the best WBI value

$x_{\min }$ is the worst WBI value.

The distribution of the WBI values (Figure 1 below) shows a concentration around $\sim 0.352$. In order to visualize the information in maps, classes are required. At first glance, the WBI values, ranging from 0 to 1 , are concentrated at 0.3 . In this context, classes are required to visualize the WBI values at subnational levels. For this purpose, quartiles are used to map the WBI values. ${ }^{6}$

\section{Figure 1. Distribution of WBI values}

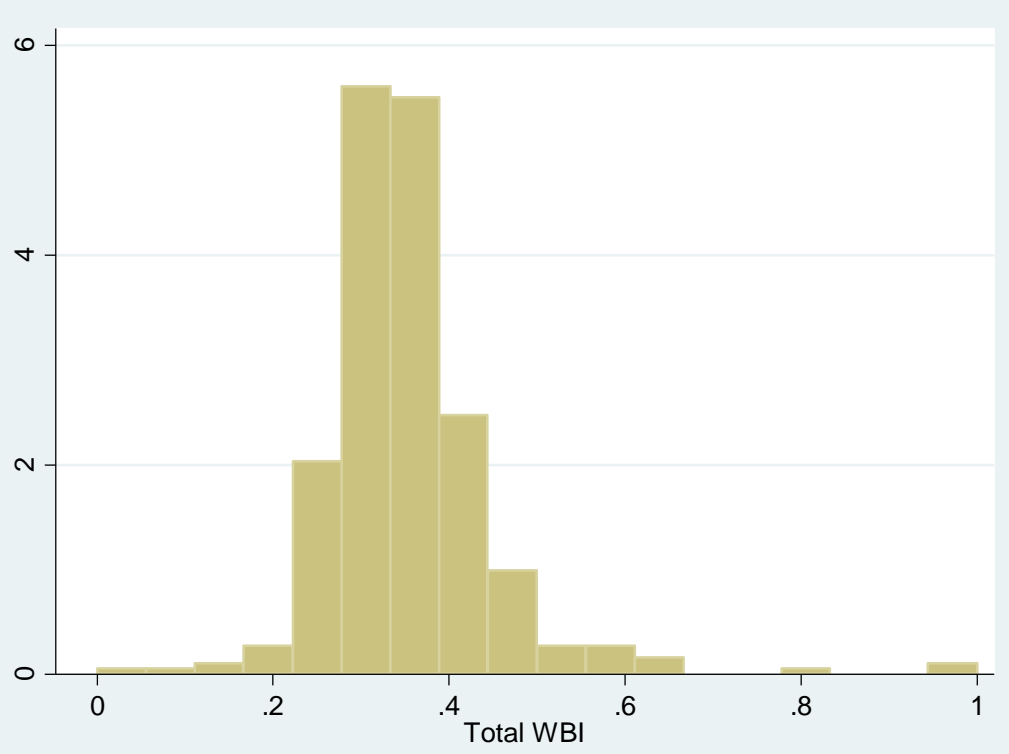

The top three municipalities (Table 3 below and mapped in green in Figure $2^{7}$ below) are the main municipalities (capital cities) of the three most important departments in Bolivia.

5 The normalization was required, since the WBI values range from 0.012 to 20.143 . Therefore, in order to have a more interpretable measure, the values were normalized from 0.000 to $1.000,0.000$ being the municipality with the lowest level of wellbeing.

${ }^{6}$ For a detailed list of all WBI values, please see Appendix 2.

${ }^{7}$ All the maps were generated using DevInfo software (www.devinfo.org), which was developed by UNICEF. Its aim is to help monitor the MDGs progress of countries. 
Figure 2. Total WBI values estimated by P2D at subnational levels for Bolivia

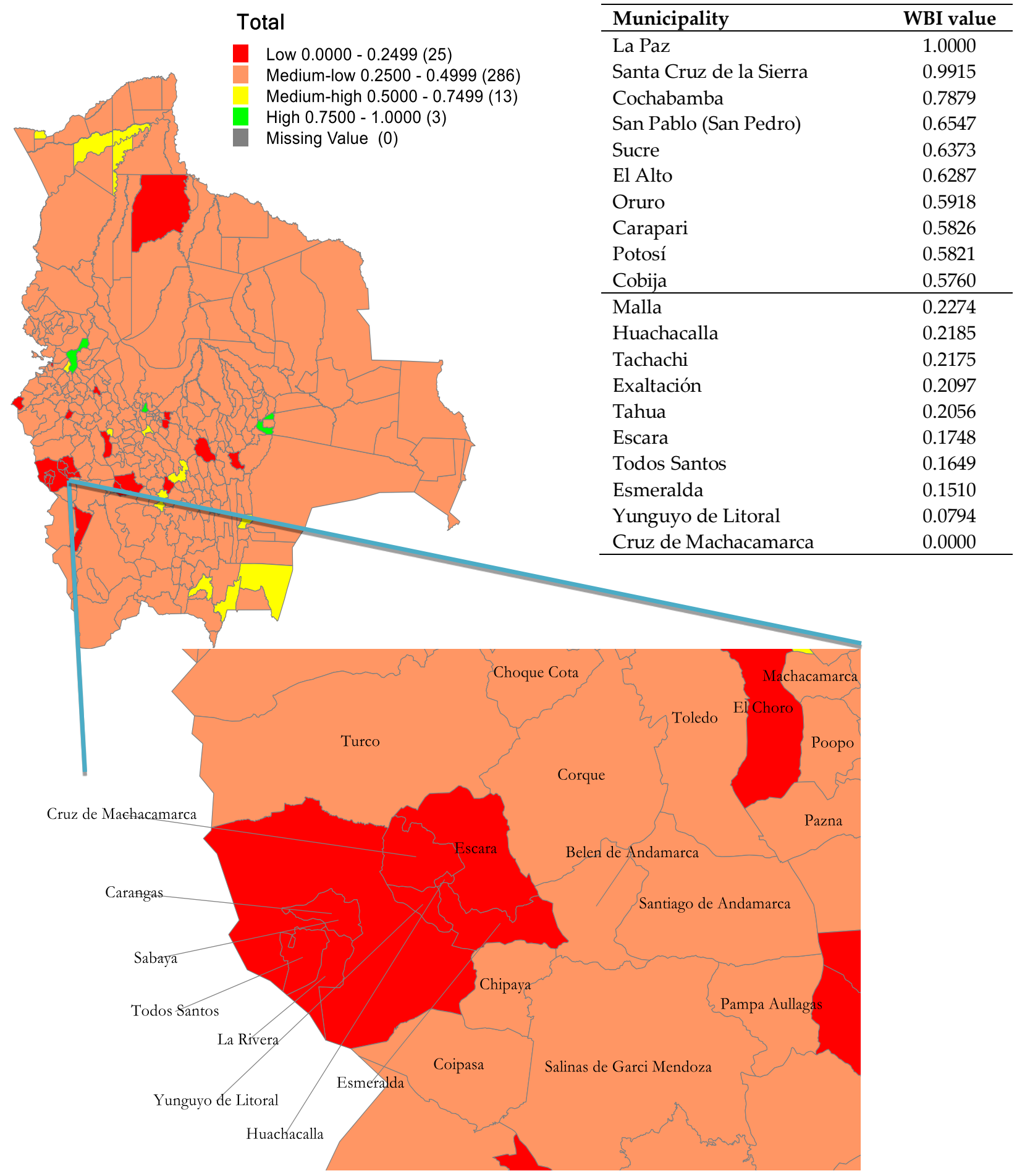

Table 3. Top and bottom 10 municipalities by WBI values

\begin{tabular}{lc}
\hline Municipality & WBI value \\
\hline La Paz & 1.0000 \\
Santa Cruz de la Sierra & 0.9915 \\
Cochabamba & 0.7879 \\
San Pablo (San Pedro) & 0.6547 \\
Sucre & 0.6373 \\
El Alto & 0.6287 \\
Oruro & 0.5918 \\
Carapari & 0.5826 \\
Potosí & 0.5821 \\
Cobija & 0.5760 \\
\hline Malla & 0.2274 \\
Huachacalla & 0.2185 \\
Tachachi & 0.2175 \\
Exaltación & 0.2097 \\
Tahua & 0.2056 \\
Escara & 0.1748 \\
Todos Santos & 0.1649 \\
Esmeralda & 0.1510 \\
Yunguyo de Litoral & 0.0794 \\
Cruz de Machacamarca & 0.0000 \\
\hline
\end{tabular}

There are 25 municipalities that have low WBI scattered around the map, and most of the municipalities (286) are concentrated in the medium-low class. Almost all of the bottom municipalities with low WBI values are located in the west of Bolivia. It is clear that municipalities 
with the worst WBI value (including Huachacalla, Escara, Cruz de Machacamarca, Yunguyo de Litoral, Esmeralda and Todos Santos) are located near each other; therefore, there are policy implications, in the sense that the government should pay more attention to these areas (located in the rural area of Oruro city).

The average WBI value for each class was obtained and distances between classes were calculated. As shown in Table 4 below, the biggest difference, on average, is between high and low classes (342\%). By classifying the municipalities by quartiles, the top three municipalities (WBI $=0.925$ average) are far away from the 25 low WBI values (WBI=0.210 average). A closer examination by dimension ${ }^{8}$ below will enrich the analysis.

Table 4. Distances among WBI values Units [\%]

\begin{tabular}{lcccc}
\hline & High & Medium-high & Medium-low & Low \\
\hline High & - & $0.355[62]$ & $0.578[166]$ & $0.717[342]$ \\
Medium-high & - & - & $0.223[64]$ & $0.362[173]$ \\
Medium-low & - & - & - & $0.139[66]$ \\
Low & - & - & - & - \\
\hline
\end{tabular}

The rationale behind de-constructing the total WBI values for each municipality by dimensions is related to the fact that the contribution of each dimension and single indicator will be visible, thereby enhancing the analysis of wellbeing at subnational levels (OECD, 2008). For the human dimension, the highest number of municipalities is in the class high (40) and the lowest number is in the class low (11). The human dimension is the most favorable dimension in terms of WBI values.

From Table 5 below, the main variables for the human dimension that are more related to the WBI are immunization vaccines for children and net enrolment rate primary ( $r=0.70$ and 0.65 respectively). Of the three dimensions, the number of municipalities in the high class is highest (23) for this dimension (Figure 3 below). In addition, two variables from this dimension (net enrolment rate secondary and drop out school rate secondary) contributed the most to the WBI (94\% and $87 \%$ respectively). Nevertheless, the social investment per capita in education and health are, on average, USD6.8 and USD3.6 (see Table 1 above); thus, from the results of the social dimension, it seems that these efforts from the government are not enough (see Figure 4 below). For this dimension, the availability of basic services such as health centers and hospitals and schools, colleges and institutes were the selected indicators, and they are highly correlated with the WBI estimation ( $r=0.95$ and 0.99 respectively ${ }^{9}$; however, the number of health centers and hospitals retains $100 \%$ of its information, whereas schools, colleges and institutes retains only 11\%. According to Figure below, the social dimension presents the worst WBI values of all dimensions. Almost all of the municipalities (321) are classified in the low class. From Table 4 above, the values, on average, for these indicators, are 3.1 and 20.2 per 100,000 population. The situation is dramatic for the health sector, since there is not enough supply of services at subnational levels, a problem closely related with low indicators for this sector (e.g., on average, nearly $50 \%$ of pregnant women have their newborns in health centers

8 The classification by quartiles applies for each single dimension.

9 Table not shown here because there are only two indicators. 
and hospitals; seven out of 10 children are vaccinated; and seven out of 100 children die before reaching one year).

Table 5. Ranking of the variables according to order of entrance in the P2D and correction factors (human dimension)

\begin{tabular}{lcc}
\hline Indicator & $|\boldsymbol{r}|$ & $\mathbf{1 - \boldsymbol { R } ^ { \mathbf { 2 } }}$ \\
\hline Immunization vaccines for children & 0.7044 & 1.0000 \\
Net enrolment rate primary & 0.6470 & 0.4723 \\
Institutional deliveries & 0.5464 & 0.6570 \\
Completion rate primary level & 0.4854 & 0.7684 \\
Net enrolment rate pre-primary & 0.4339 & 0.2451 \\
Children with suspected pneumonia & 0.4221 & 0.3689 \\
Children with diarrhoea & 0.3960 & 0.6986 \\
Drop out school rate pre-primary & 0.3888 & 0.1970 \\
Net enrolment rate secondary & 0.3452 & 0.9364 \\
Drop out school rate secondary & 0.3326 & 0.8655 \\
Drop out school rate primary & 0.1950 & 0.6397 \\
Infant mortality rate & 0.1770 & 0.7998 \\
\hline
\end{tabular}

Figure 3. WBI values for human dimension

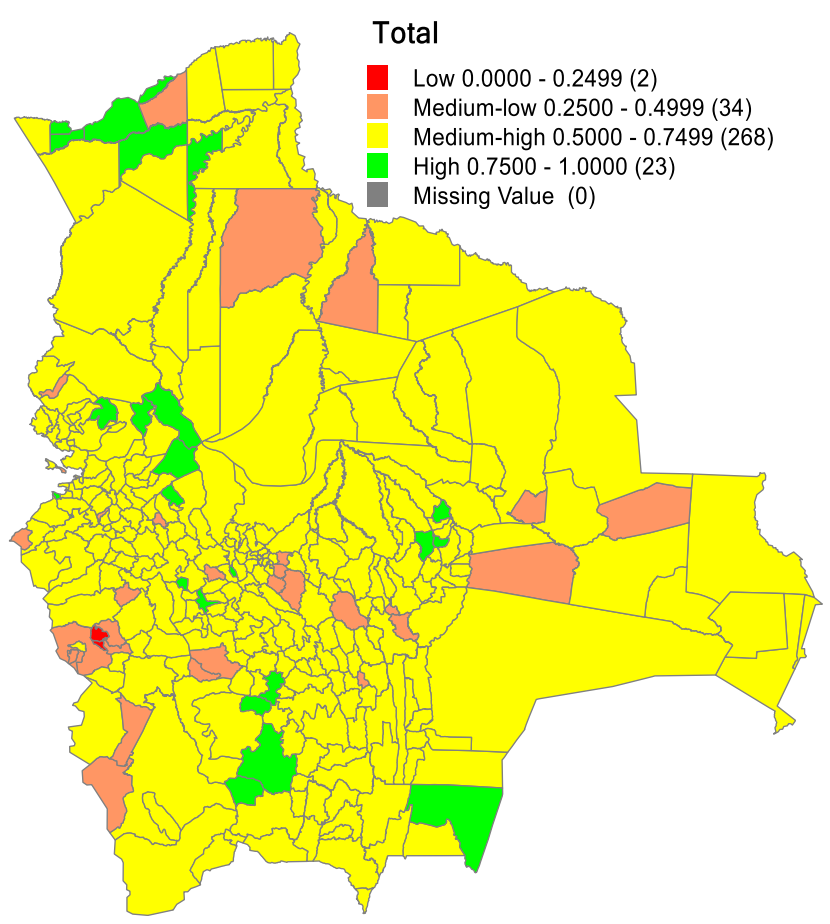

Figure 4. WBI values for social dimension

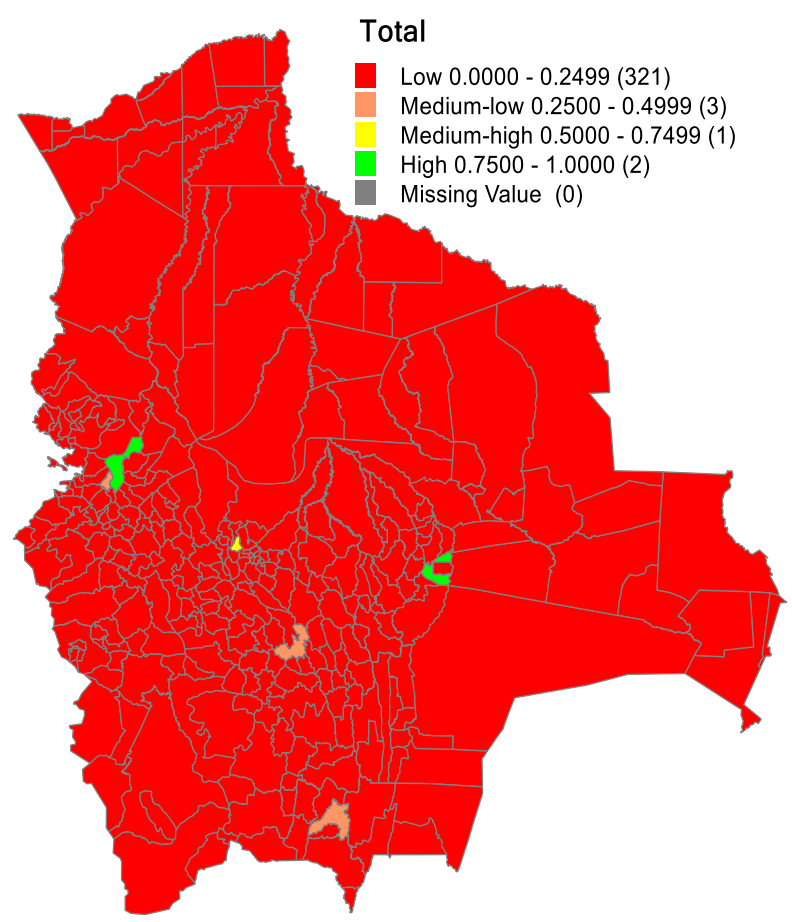

The material dimension is located in the middle of the three dimensions in terms of the WBI values (Figure 5 below). 
Figure 5. WBI values for material dimension

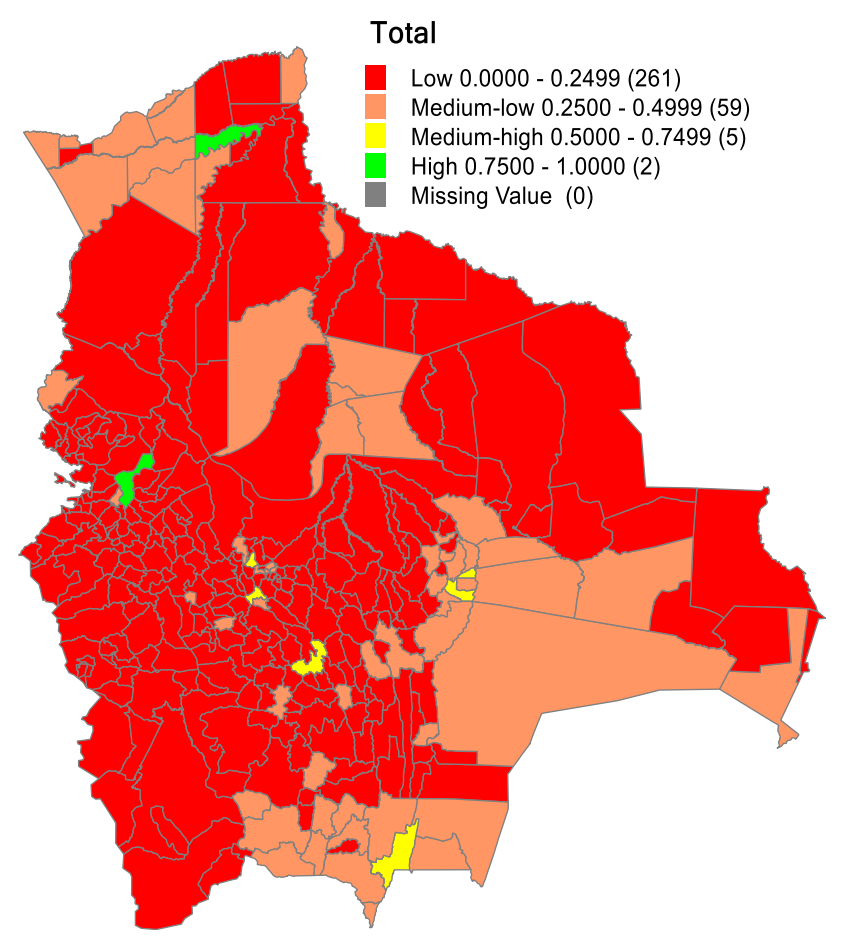

According to Table 6 below, two of the indicators in this dimension (extreme poverty and social investment in education) are highly correlated with the WBI estimation ( 0.61); however, the contribution by the extreme poverty indicator to the WBI estimation is low (17\%) compared to the availability of doctors, nurses and administrative personnel and total social investment per capita in the municipalities.

Table 6. Ranking of the variables according to order of entrance in the P2D and correction factors (material dimension)

\begin{tabular}{lcc}
\hline Indicator & $|\boldsymbol{r}|$ & $\mathbf{1}-\boldsymbol{R}^{\mathbf{2}}$ \\
\hline Social investment MDG universal education & 0.6200 & 1.0000 \\
Extreme poverty & 0.5919 & 0.1690 \\
Doctors, nurses, and administrative personnel & 0.5903 & 0.9652 \\
Total social investment & 0.5767 & 0.8760 \\
Teachers in schools and institutes & 0.5655 & 0.7581 \\
Social investment MDG infant mortality and mother health & 0.5248 & 0.4983 \\
Coverage of water & 0.5133 & 0.7230 \\
Social investment MDG poverty & 0.4798 & 0.7376 \\
Coverage of sanitation & 0.3891 & 0.7863 \\
\hline
\end{tabular}

Social investment in education retains $100 \%$ of its information and is highly correlated with the WBI estimation. This is in line with the indicators in the education sector and their improvement over the years (UDAPE and UNICEF, 2005; 2008). From Table 1 above, on average, the net enrolment rate (NER) reaches $83 \%$ and the drop out school rate for primary $6.4 \%$; however, the NER for pre-primary 
and secondary are low (31.1\% and 38.5\%) and the drop out school for the same levels are high ( 9\%). The availability of doctors, nurses and administrative personnel (as in the social dimension with the number of health centers and hospitals) retains $97 \%$ of its information, reflecting the importance of having a greater supply of these personnel and associated infrastructure in the municipalities, considering that, on average, only USD3.6 per capita is invested in health at subnational levels.

Finally, from the three dimensions, the material one is the one that contributes all of its information and is highly correlated with WBI estimation (Table 7 below). Therefore, having personnel (doctors, nurses and teachers) in the health centers, hospitals and schools accompanied by social investment in health and education are key elements to improve wellbeing at subnational levels.

Table 7. Ranking of the dimensions according to order of entrance in the DP2 and correction factors

\begin{tabular}{lrc}
\hline Dimensions & $|\boldsymbol{r}|$ & $\mathbf{1}-\boldsymbol{R}^{\mathbf{2}}$ \\
\hline Material & 0.8603 & 1.0000 \\
Social & 0.7014 & 0.6943 \\
Human & 0.6722 & 0.8905 \\
\hline
\end{tabular}

\subsubsection{Analyzing the bottom WBI values by dimension}

As seen in Table 3 above, most of the municipalities in the "top 10" are the main capital municipalities in Bolivia. Therefore, it is not surprising that these municipalities have high WBI values, since these cities have better values for all indicators compared to all other rural municipalities. However, it is interesting to explore the "bottom 10" municipalities in order to analyze more deeply the reasons or factors affecting their WBI values and their performance in the rankings. Table 8 below shows the municipalities with lowest WBI values that fall into two (green) or three dimensions (red). In other words, municipalities in green have the lowest WBI values per dimension. In addition, those in red have the lowest WBI values per dimension plus the lowest WBI values in general. The three municipalities highlighted in red belong to the Department of Oruro, located in the east region of Bolivia (see Figure above). For instance, Todos Santos, Yunguyo de Litoral and Cruz de Machacamarca have the lowest WBI values in all three dimensions.

As per Table 6 above, health personnel (doctors, nurses and administrative staff) is an important variable that retains $97 \%$ of its information $(r=0.59)$ in WBI estimation. For the fourth municipalities in green in Table 8 below, in the material dimension (columns 1 and 2), the availability of health personnel is very low. For instance, of the four, two (Todos Santos and Carangas) have only one nurse and one health centre. Even though the population in these municipalities is not high (388 and 556 persons, according to the National Statistics Institute, 2013) the situation is really dramatic for the Cruz de Machacamarca municipality. According to the INE (2013), the population for $2007^{10}$ in this municipality was 2,176 persons, and they have neither a health centre nor health personnel in the area.

\footnotetext{
${ }^{10}$ Information for health personnel is available for 2007. Information was provided by the Economic and Social Policy Analysis Bureau (2009).
} 
Table 8. WBI Values for the bottom 10 municipalities by dimension

\begin{tabular}{|c|c|c|c|c|c|c|c|}
\hline \multicolumn{2}{|c|}{$\begin{array}{l}\text { WBI material } \\
\text { dimension }\end{array}$} & \multicolumn{2}{|c|}{ WBI social dimension } & \multicolumn{2}{|c|}{ WBI human dimension } & \multicolumn{2}{|c|}{ WBI total } \\
\hline Municipality & $\begin{array}{c}\text { WBI } \\
\text { value }\end{array}$ & Municipality & $\begin{array}{c}\text { WBI } \\
\text { value }\end{array}$ & Municipality & $\begin{array}{c}\text { WBI } \\
\text { value }\end{array}$ & Municipality & $\begin{array}{c}\text { WBI } \\
\text { value }\end{array}$ \\
\hline Ingavi & 0.0453 & Todos Santos & 0.0029 & Alalay & 0.4085 & Malla & 0.2274 \\
\hline Tahua & 0.0438 & Tacachi & 0.0026 & Catacora & 0.3973 & Huachacalla & 0.2185 \\
\hline Todos Santos & 0.0431 & Coipasa & 0.0021 & Pailón & 0.3673 & Tacachi & 0.2175 \\
\hline Apolo & 0.0418 & Carangas & 0.0021 & Todos Santos & 0.3515 & Exaltación & 0.2097 \\
\hline Carangas & 0.0370 & $\begin{array}{l}\text { Nazacara de } \\
\text { Pacajes }\end{array}$ & 0.0015 & Huachacalla & 0.3496 & Tahua & 0.2056 \\
\hline $\begin{array}{l}\text { Yunguyo de } \\
\text { Litoral }\end{array}$ & 0.0280 & Escara & 0.0015 & Escara & 0.3011 & Escara & 0.1748 \\
\hline Chacarilla & 0.0206 & La Rivera & 0.0015 & Esmeralda & 0.2948 & Todos Santos & 0.1649 \\
\hline Tacobamba & 0.0197 & Esmeralda & 0.0014 & Exaltación & 0.2939 & Esmeralda & 0.1510 \\
\hline $\begin{array}{l}\text { Cruz de } \\
\text { Machacamarca }\end{array}$ & 0.0015 & $\begin{array}{l}\text { Yunguyo de } \\
\text { Litoral }\end{array}$ & 0.0008 & $\begin{array}{l}\text { Yunguyo de } \\
\text { Litoral }\end{array}$ & 0.1633 & $\begin{array}{l}\text { Yunguyo de } \\
\text { Litoral }\end{array}$ & 0.0794 \\
\hline El Choro & 0.0000 & $\begin{array}{l}\text { Cruz de } \\
\text { Machacamarca }\end{array}$ & 0.0000 & $\begin{array}{l}\text { Cruz de } \\
\text { Machacamarca }\end{array}$ & 0.0000 & $\begin{array}{l}\text { Cruz de } \\
\text { Machacamarca }\end{array}$ & 0.0000 \\
\hline \multicolumn{6}{|c|}{ At least 2 dimensions } & \multicolumn{2}{|c|}{3 dimensions } \\
\hline
\end{tabular}

Total social investment contributes to the material dimension, with $88 \%$ of its information (see Table 6 above). Analysis of this indicator shows Cruz de Machacamarca again has the worst values (Figure 2 below). Over the period 2000 to 2007, this municipality received on average USD1.9 for each person, compared to USD4.1, USD8.2 and USD13.4 for Yunguyo de Litoral, Carangas and Todos Santos respectively. Some other municipalities with a similar population size as that of Cruz de Machacamarca, such as Tacachi $(2,316)$, Huachacalla $(2,152)$, and San Antonio de Esmoruco $(2,176)$ received USD8.5, USD5.7 and USD14.1 respectively in 2007.

In the social dimension, the availability of health centers and hospitals and schools, colleges and institutes are highly correlated with WBI estimation; however, only the first of these retains $100 \%$ of its information in the WBI calculation. In terms of availability of health personnel in these municipalities, on average, they have one doctor, four nurses and two health centers. In terms of education, Cruz de Machacamarca does not have any school or teacher in the area, whereas the other five have at least one school and a teacher (Yunguyo de Litoral), reaching 17 teachers in Todos Santos. Therefore, this fact relates to the lack of information available for any indicator in the education sector for Cruz de Machacamarca. All the children may attend a school near this municipality (such as Escara, Huachacalla or Yunguyo de Litoral, see Table 8 above). Escara and Carangas, the two new municipalities in green in this dimension (columns 3 and 4), have one and two schools and eight and three teachers respectively. 
Figure 6. Total social investment per capita, 2000-2007 (selected municipalities)

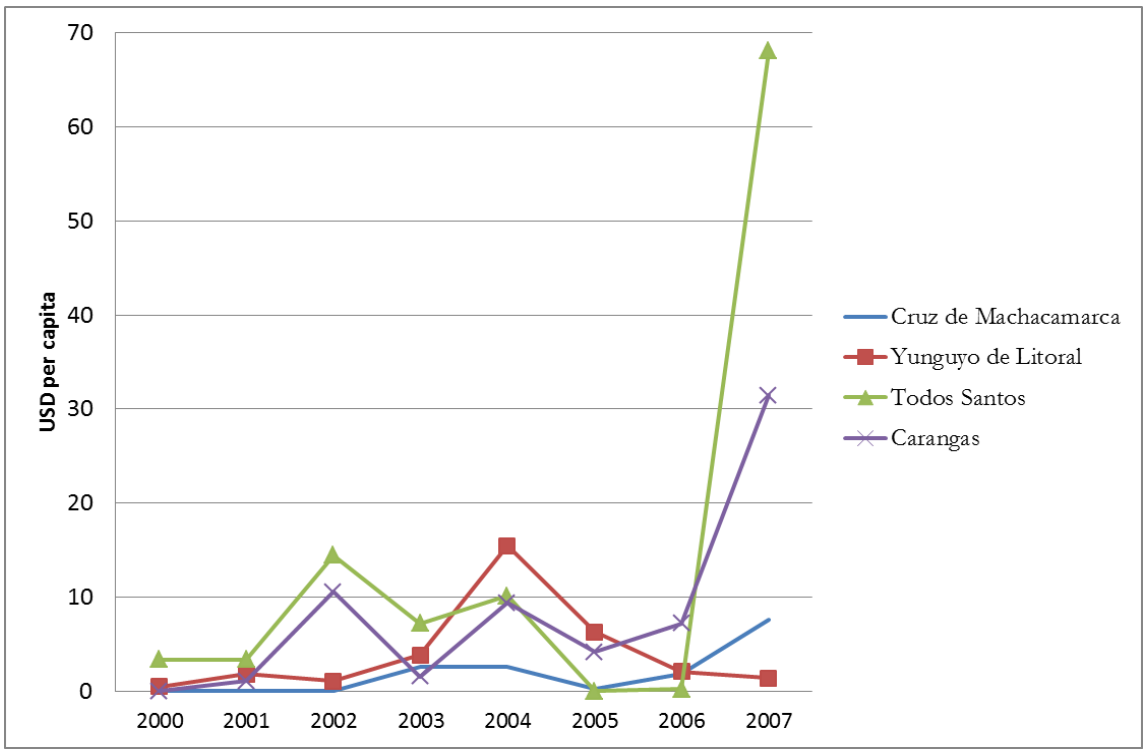

Source: Elaborated based on social investment data at subnational levels by the Economic and Social Policy Analysis Bureau (2010)

The performance of the municipalities in the third column of Table 8 above is reflected in Figures 7 and 9 below.

Figure 7. Immunization vaccines for children, 2002-2011 (selected municipalities)

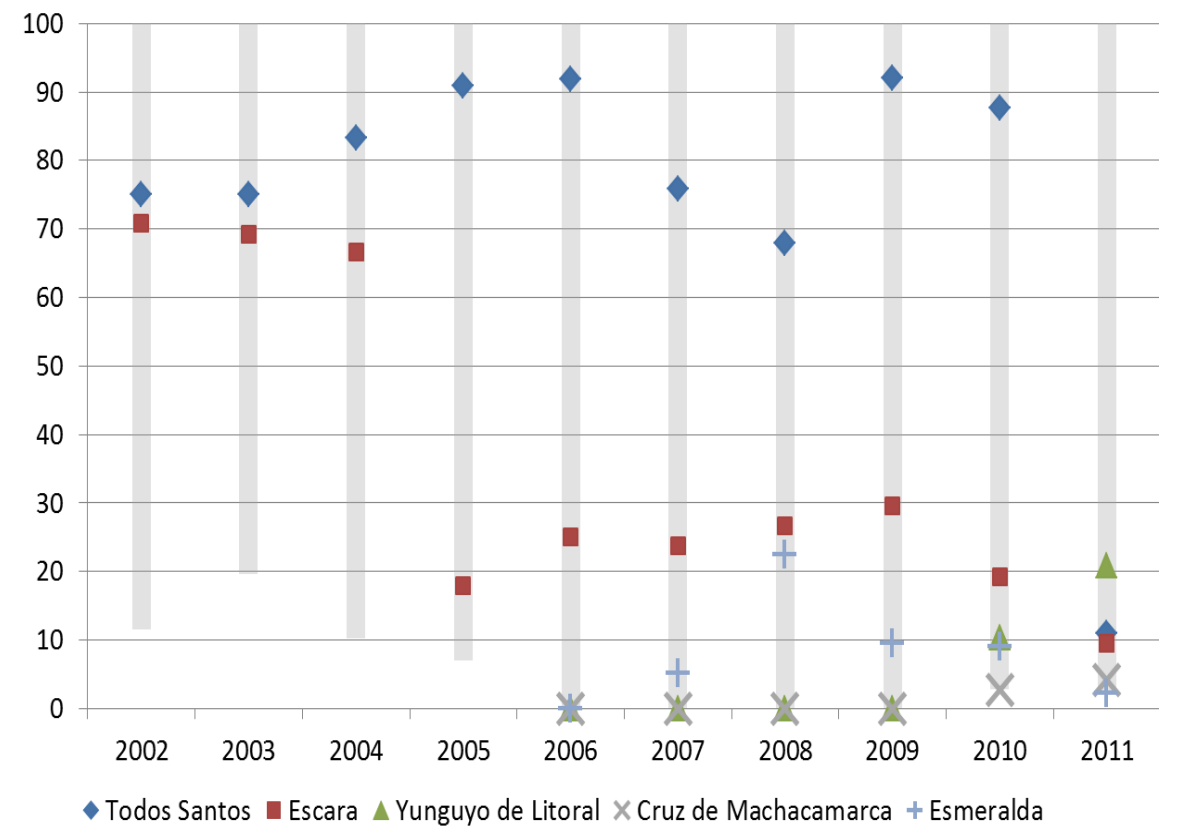

Source: Elaborated based on municipal indicator. Dossier of Economic and Social Statistics data by UDAPE (2010b) 
Figure 8. Net enrolment rate primary, 2001-2010 (selected municipalities)

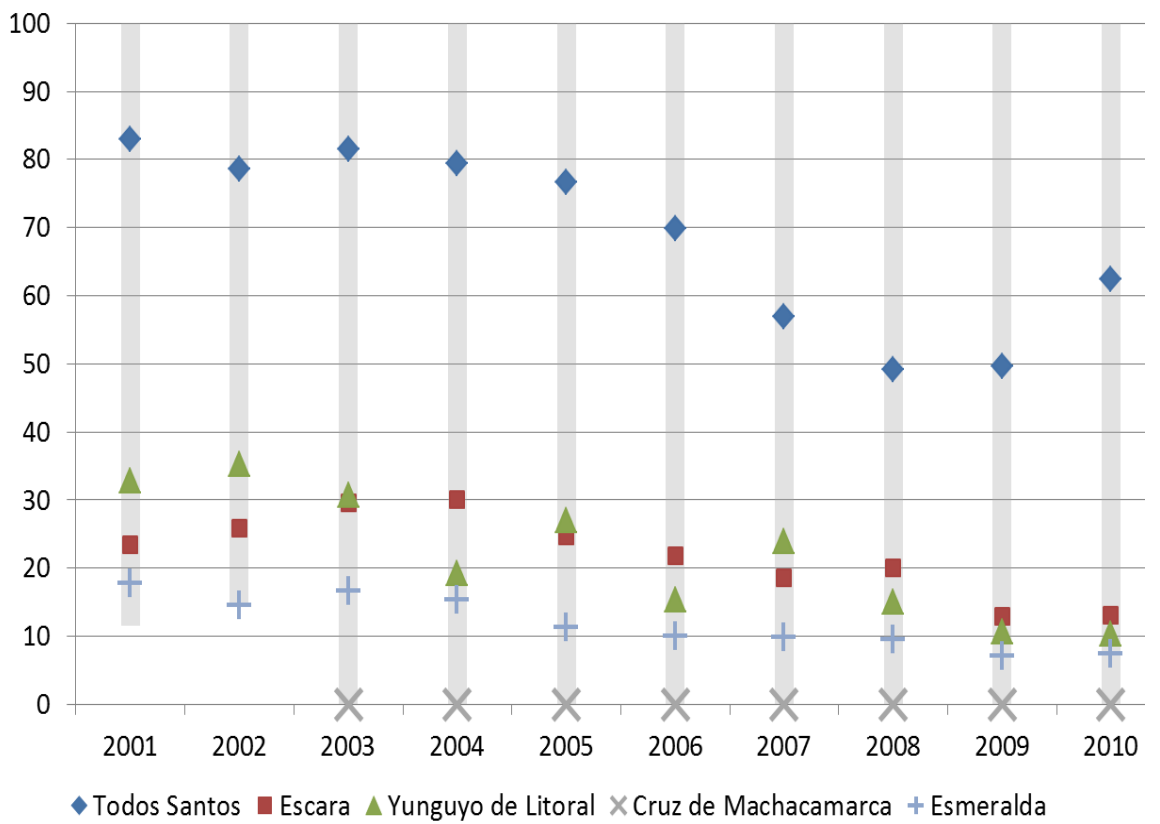

Source: Elaborated based on municipal indicator. Dossier of Economic and Social Statistics data by UDAPE (2010b)

The two indicators that are highly related to the WBI estimation are considered there. The grey line shows the range (maximum and minimum) of possible values for each indicator. Cruz de Machacamarca gets the lowest values for both indicators; however, as mentioned before, since the municipality does not have a school in the area, the NER indicator is not collected. Todos Santos gets the best values for both indicators, except for 2011 in the immunization vaccines indicator. Both figures are in concordance with the WBI ranking, although it is important to mention that Todos Santos has values that are closer to those for the top municipalities ( $69 \%$ and $75 \%$ respectively) but the highest values for other "negative" indicators among these municipalities (e.g., Infant mortality rate (146.2)), drop out school rate pre-primary, primary and secondary (average 42.2)).

The social investment in the municipalities is essential in order to improve the conditions of their populations. Over the period from 2000 to 2007, the social investment per capita for some of the bottom 10 municipalities with the worst WBI values according to their WBI ranking benefits, such as Cruz de Machacamarca, required greater attention (Figure 9 below). For instance, from 2000 to 2002 there was no social investment; however, from 2003 the investment reached USD7.6 per capita in 2007. In contrast, from Figures 7 and 8 above, the municipality of Todos Santos has better indicators than do other municipalities, as well as greater social investment. From 2000 to 2003 Todos Santos had the highest per capita social investment, reaching the highest amount in 2007 among all the bottom municipalities (USD44.4). In contrast, the top 10 municipalities received, on average during the 2000 to 2007 period, USD33.8 per capita. 
Figure 9. Total social investment per capita, 2000-2008 (selected municipalities)

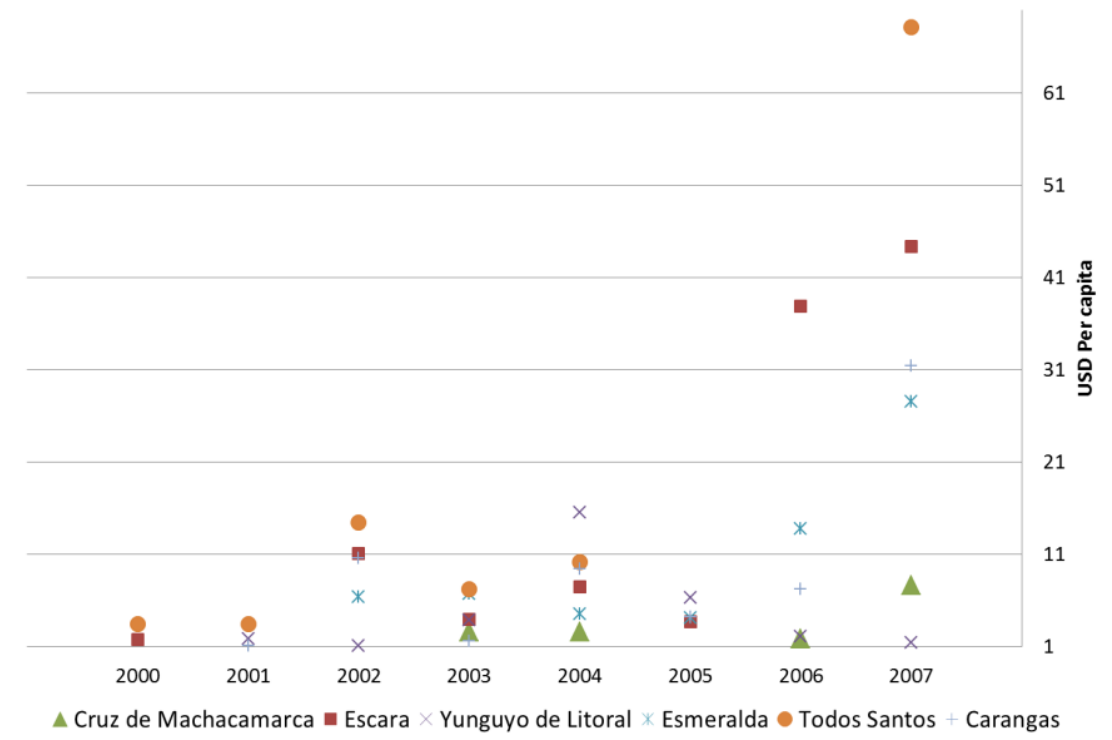

Source: Elaborated based on social investment data at subnational levels by UDAPE (2010a)

\subsection{A comparative analysis}

As stated above, the main feature of the DP2 method is to estimate "distances," taking as "reference" a municipality with the worst values in its single indicators. Considering that we are interested in comparing the evolution over time of the WBI values for each municipality, two periods of time are used for this purpose: from 2000 to 2005 and from 2006 to 2011. The two periods shed light on the progress, in terms of wellbeing, for each municipality under the former and current (under the National Development Plan's scope) government's policies in terms of education, health and social investment. In order to achieve the objective detailed before, a "reference" municipality is taken for both periods. The municipality of Cruz de Machacamarca has the worst values, and the "distances" are estimated based on the values for each municipality. This procedure allows us to compare WBI values for both periods, taking as a reference the same municipality. For the first comprehensive analysis (from 2000 to 2011, as detailed before), all the single indicators were added to estimate the WBI values; however, for this two-period analysis, the estimation considers just those indicators that have information in both periods (e.g., children with diarrhoea has information from 2000 to 2009). Table 9 below shows the indicators that were included in the WBI estimation for both periods.

Comparing Table 9 below with Table 1 above, the indicators that do not have information for both periods, that is for 2000 to 2005 and 2006 to 2011, were excluded from the analysis (e.g., infant mortality rate), in order to have comparable indicators to analyze the evolution of WBI values over time. It is important to mention that the two indicators that matched the "social dimension" are not included in the following analysis; therefore, the analysis by dimension was not included either. 
Table 9. Indicators and timeframe for WBI 2000-2011 estimation

\begin{tabular}{|c|c|c|c|c|c|c|c|c|c|c|c|c|}
\hline \multirow{2}{*}{ Indicators (unit) } & \multicolumn{12}{|c|}{ Timeframe of Data (from 2000 to 2011) } \\
\hline & 00 & 01 & 02 & 03 & 04 & 05 & 06 & 07 & 08 & 09 & 10 & 11 \\
\hline Immunization vaccines for children (percentage) & & & $\checkmark$ & $\checkmark$ & $\checkmark$ & $\checkmark$ & $\checkmark$ & $\checkmark$ & $\checkmark$ & $\checkmark$ & $\checkmark$ & $\checkmark$ \\
\hline Institutional deliveries (percentage) & & & $\checkmark$ & $\checkmark$ & $\checkmark$ & $\checkmark$ & $\checkmark$ & $\checkmark$ & $\checkmark$ & $\checkmark$ & $\checkmark$ & $\checkmark$ \\
\hline Children with diarrhoea (percentage) & $\checkmark$ & $\checkmark$ & $\checkmark$ & $\checkmark$ & $\checkmark$ & $\checkmark$ & $\checkmark$ & $\checkmark$ & $\checkmark$ & $\checkmark$ & & \\
\hline Children with suspected pneumonia (percentage) & $\checkmark$ & $\checkmark$ & $\checkmark$ & $\checkmark$ & $\checkmark$ & $\checkmark$ & $\checkmark$ & $\checkmark$ & $\checkmark$ & $\checkmark$ & & \\
\hline Net enrolment rate pre-primary (percentage) & $\checkmark$ & $\checkmark$ & $\checkmark$ & $\checkmark$ & $\checkmark$ & $\checkmark$ & $\checkmark$ & $\checkmark$ & $\checkmark$ & $\checkmark$ & $\checkmark$ & \\
\hline Net enrolment rate primary (percentage) & $\checkmark$ & $\checkmark$ & $\checkmark$ & $\checkmark$ & $\checkmark$ & $\checkmark$ & $\checkmark$ & $\checkmark$ & $\checkmark$ & $\checkmark$ & $\checkmark$ & \\
\hline Net enrolment rate secondary (percentage) & $\checkmark$ & $\checkmark$ & $\checkmark$ & $\checkmark$ & $\checkmark$ & $\checkmark$ & $\checkmark$ & $\checkmark$ & $\checkmark$ & $\checkmark$ & $\checkmark$ & \\
\hline Completion rate primary level (percentage) & $\checkmark$ & $\checkmark$ & $\checkmark$ & $\checkmark$ & $\checkmark$ & $\checkmark$ & $\checkmark$ & $\checkmark$ & $\checkmark$ & $\checkmark$ & $\checkmark$ & \\
\hline Drop out school rate pre-primary (percentage) & $\checkmark$ & $\checkmark$ & $\checkmark$ & $\checkmark$ & $\checkmark$ & $\checkmark$ & $\checkmark$ & $\checkmark$ & $\checkmark$ & & & \\
\hline Drop out school rate primary (percentage) & $\checkmark$ & $\checkmark$ & $\checkmark$ & $\checkmark$ & $\checkmark$ & $\checkmark$ & $\checkmark$ & $\checkmark$ & $\checkmark$ & & & \\
\hline Drop out school rate secondary (percentage) & $\checkmark$ & $\checkmark$ & $\checkmark$ & $\checkmark$ & $\checkmark$ & $\checkmark$ & $\checkmark$ & $\checkmark$ & $\checkmark$ & & & \\
\hline Social investment MDG poverty (per capita USD) & $\checkmark$ & $\checkmark$ & $\checkmark$ & $\checkmark$ & $\checkmark$ & $\checkmark$ & $\checkmark$ & $\checkmark$ & & & & \\
\hline $\begin{array}{l}\text { Social investment MDG infant mortality and } \\
\text { mother health (per capita USD) }\end{array}$ & $\checkmark$ & $\checkmark$ & $\checkmark$ & $\checkmark$ & $\checkmark$ & $\checkmark$ & $\checkmark$ & $\checkmark$ & & & & \\
\hline $\begin{array}{l}\text { Social investment MDG universal education (per } \\
\text { capita USD) }\end{array}$ & $\checkmark$ & $v$ & $\checkmark$ & $\checkmark$ & $\checkmark$ & $\checkmark$ & $\checkmark$ & $\checkmark$ & & & & \\
\hline Total social investment (per capita USD) & $\checkmark$ & $\checkmark$ & $\checkmark$ & $\checkmark$ & $\checkmark$ & $\checkmark$ & $\checkmark$ & $\checkmark$ & & & & \\
\hline
\end{tabular}

\subsubsection{Period from 2000 to 2005 vs. period from 2006 to 2011}

The procedure for the estimation of the WBI for these periods is the same as that applied before (for 2000-2011); however, two stages instead of three were needed, since the WBI values for the dimensions are not included in the analysis. In the first stage, the $\mathrm{DP}_{2}$ method of aggregation was applied to those single indicators which have more than a year of information. For instance, for net enrolment rate for primary, the WBI values were estimated using the available information, that is, from 2000 to 2005 (see Table 9 above). The second stage consisted of using the values obtained for each single indicator in the first stage to estimate the WBI values for the period from 2000 to 2005.

Figure 6 below shows both WBI distributions. The figure suggests that for the period from 2006 to 2011, most of the normalized values of wellbeing are aggregated at 0.425 - a wellbeing value less than that for the period from 2000 to 2005 (0.544). At first glance, it appears that the levels of wellbeing at subnational levels had decreased between the periods of time analyzed. 
Figure 10. Distributions for WBI values by period of time
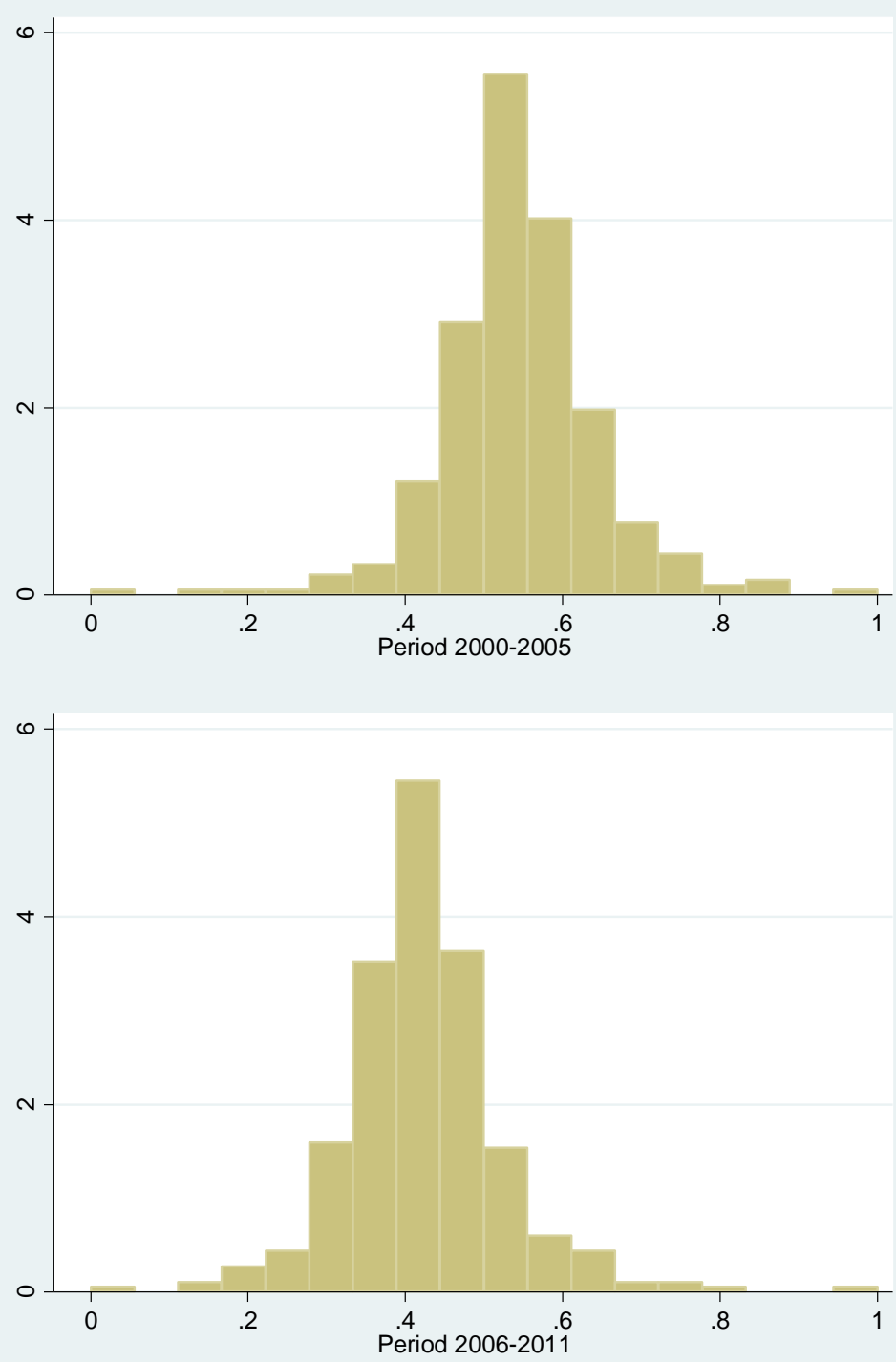

Table 10 below offers a description of the indicators that contributed most to the WBI estimation $\left(1-R^{2}\right)$ and their absolute linear correlation $|r|$, with the resulting composite index. Immunization vaccines for children and net enrolment rate for primary contributed most to the estimation for the periods from 2000 to 2005 and 2006 to 2011 respectively. It is worth noting that total social investment per capita increased its contribution from $76 \%$ in the period from 2000 to 2005 to $96 \%$ in the period from 2006 to 2011, resulting in the second most important "contributor" to the WBI estimation in the period from 2006 to 2011. 
Table 10. Ranking of the variables according to order of entrance in the P2D and correction factors for 2000-2005 and 2006-2011

2000-2005

\begin{tabular}{lcc}
\hline Indicator & $|\boldsymbol{r}|$ & $\mathbf{1 - \boldsymbol { R } ^ { \mathbf { 2 } }}$ \\
\hline Net enrolment rate primary & 0.668 & 1.000 \\
Immunization vaccines for children & 0.574 & 0.695 \\
Total social investment & 0.503 & 0.756 \\
Institutional deliveries & 0.494 & 0.925 \\
Social investment MDG infant mortality and mother health & 0.465 & 0.571 \\
Completion rate primary level & 0.450 & 0.642 \\
Social investment MDG universal education & 0.413 & 0.921 \\
Social investment MDG poverty & 0.406 & 0.724 \\
Net enrolment rate pre-primary & 0.401 & 0.248 \\
Children with suspected pneumonia & 0.367 & 0.548 \\
Net enrolment rate secondary & 0.338 & 0.309 \\
Children with diarrhoea & 0.328 & 0.801 \\
Drop out school rate pre-primary & 0.273 & 0.925 \\
Drop out school rate secondary & 0.218 & 0.844 \\
Drop out school rate primary & 0.076 & 0.629
\end{tabular}

2006-2011

\begin{tabular}{lcc}
\hline Indicator & $|\boldsymbol{r}|$ & $\mathbf{1}-\boldsymbol{R}^{\mathbf{2}}$ \\
\hline Immunization vaccines for children & 0.696 & 1.000 \\
Net enrolment rate primary & 0.630 & 0.411 \\
Total social investment & 0.624 & 0.958 \\
Social investment MDG infant mortality and mother health & 0.574 & 0.342 \\
Social investment MDG universal education & 0.555 & 0.393 \\
Institutional deliveries & 0.525 & 0.619 \\
Net enrolment rate primary & 0.520 & 0.253 \\
Children with diarrhoea & 0.519 & 0.633 \\
Completion rate primary level & 0.492 & 0.650 \\
Social investment MDG poverty & 0.465 & 0.222 \\
Children with suspected pneumonia & 0.458 & 0.550 \\
Drop out school rate secondary & 0.374 & 0.199 \\
Net enrolment rate secondary & 0.363 & 0.953 \\
Drop out school rate pre-primary & 0.266 & 0.880 \\
Drop out school rate primary & 0.221 & 0.722 \\
\hline
\end{tabular}


Figure 11 and Figure 12 below show the values for both periods.

Figure 11. WBI values for 2000-2005

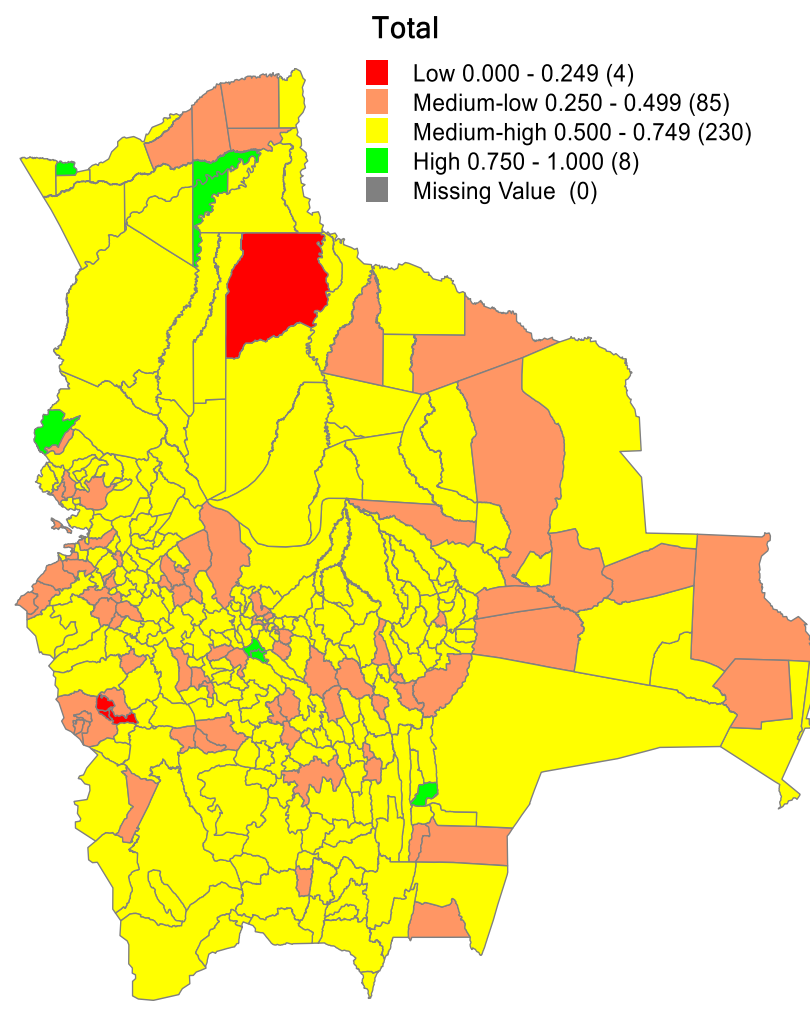

Figure 12. WBI values for 2006-2011 period

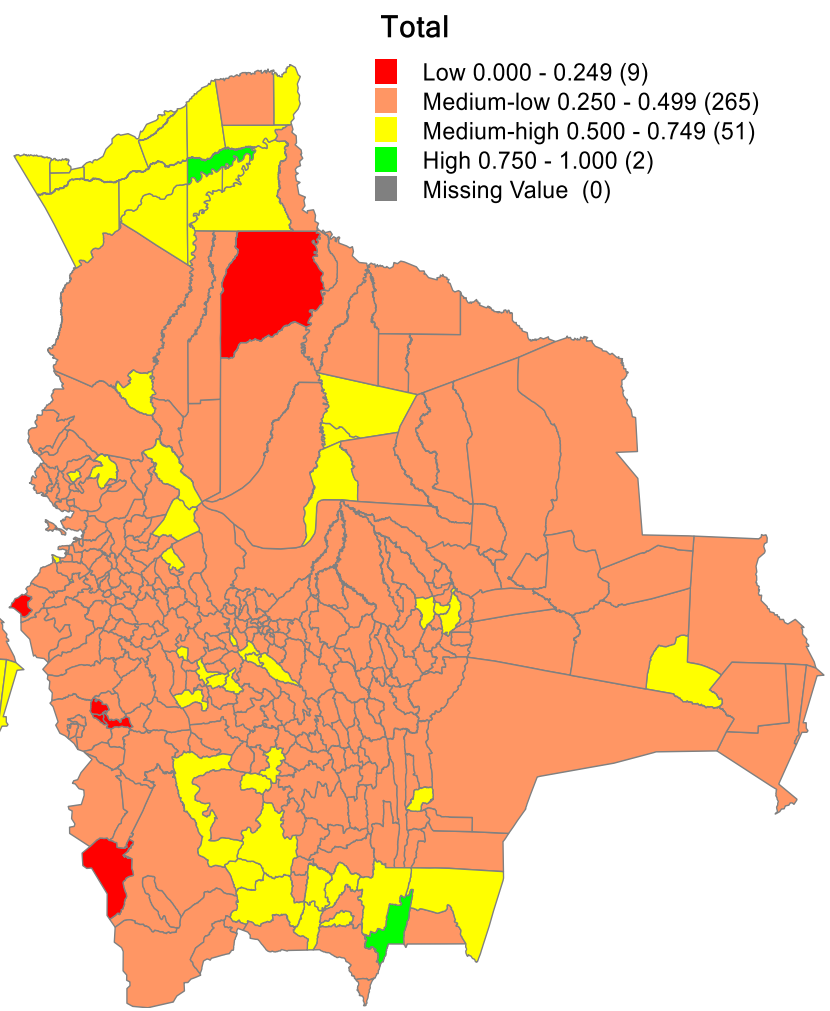

In general, most of the municipalities changed their condition from medium-high to medium-low between periods. The number of municipalities with higher WBI values reduced between periods from eight to two. In addition, Table 11 below shows the bottom 10 municipalities, according to their WBI values. As analyzed in the period 2000-2011 Cruz de Machacamarca, Yunguyo de Litoral, Esmeralda, and Escara appear in both periods.

Table 11. Lowest WBI values for 2000-2005 and 2006-2011 periods

\begin{tabular}{lclc}
\hline \multicolumn{1}{c}{ 2000-2005 } & & \multicolumn{2}{c}{ 2006-2011 } \\
\hline Municipality & WBI Value & Municipality & WBI Value \\
\hline Eureka (Santos Mercado) & 0.365 & Escara & 0.255 \\
Catacora & 0.359 & San Pedro de Quemes & 0.227 \\
Escara & 0.327 & Tito Yupanqui & 0.221 \\
Ingavi & 0.326 & Catacora & 0.200 \\
Pailón & 0.295 & Tacachi & 0.190 \\
Nacebe (Santa Rosa de & & Exaltación & 0.178 \\
Abuna) & 0.282 & Esmeralda & 0.175 \\
Exaltación & 0.245 & Huachacalla & 0.161 \\
Esmeralda & 0.218 & Yunguyo de Litoral & 0.132 \\
Yunguyo de Litoral & 0.159 & Cruz de Machacamarca & 0.000 \\
Cruz de Machacamarca & 0.000 & &
\end{tabular}


These results suggest that subnational levels reveal important "differences" among municipalities, and, in line with UDAPE and UNICEF (2005 \& 2008), the values for the capital cities are not the real scenario and do not necessarily reflect the situation for the rest of municipalities, in this case, in terms of wellbeing. The results are interesting, considering that the current government was elected in 2006 and since then some redistributive policies have been allocated in order to improve the condition of the most vulnerable and poor people such as, conditional cash transfers (e.g., the Juancito Pinto bonus aimed at retaining children in schools, and the Juana Azurduy de Padilla bonus aimed at improving pre and post control in women); the continuity to the establishment of an insurance scheme across Bolivia with universal, comprehensive and free coverage, to provide health benefits to children from birth to five years and pregnant women from the beginning of pregnancy until six months postpartum; and stable levels of social investment at national levels (17\% of GDP). Despite these efforts, the wellbeing at subnational levels reveals important disparities that the population faces.

The complementary analysis below (Figure 13) was carried out on an annual basis (2002, 2003, 2006 and 2007) to see possible changes in the WBI values over the years to contrast with the findings obtained for the period 2000-2005 and 2006-2011.

Figure 13a. WBI values for 2002, 2003, 2006 and 2007
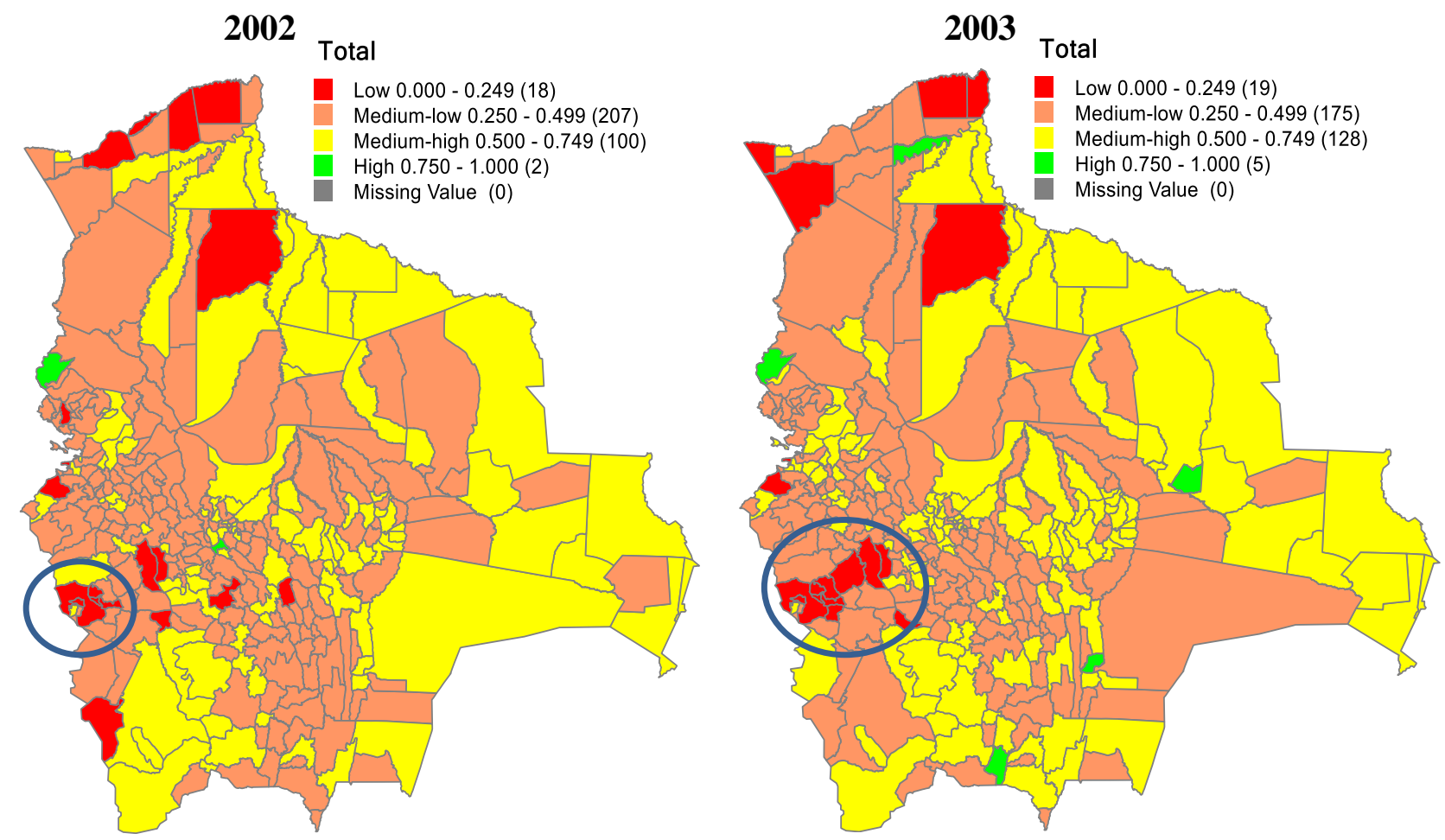
Figure 13b. WBI values for 2002, 2003, 2006 and 2007

2006

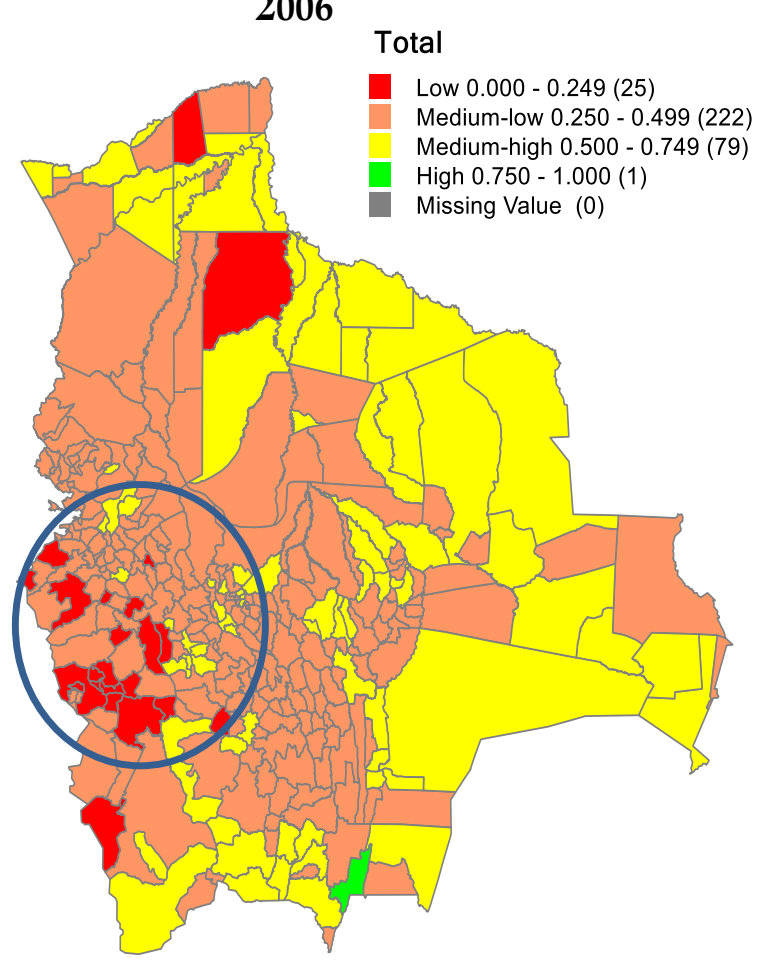

2007

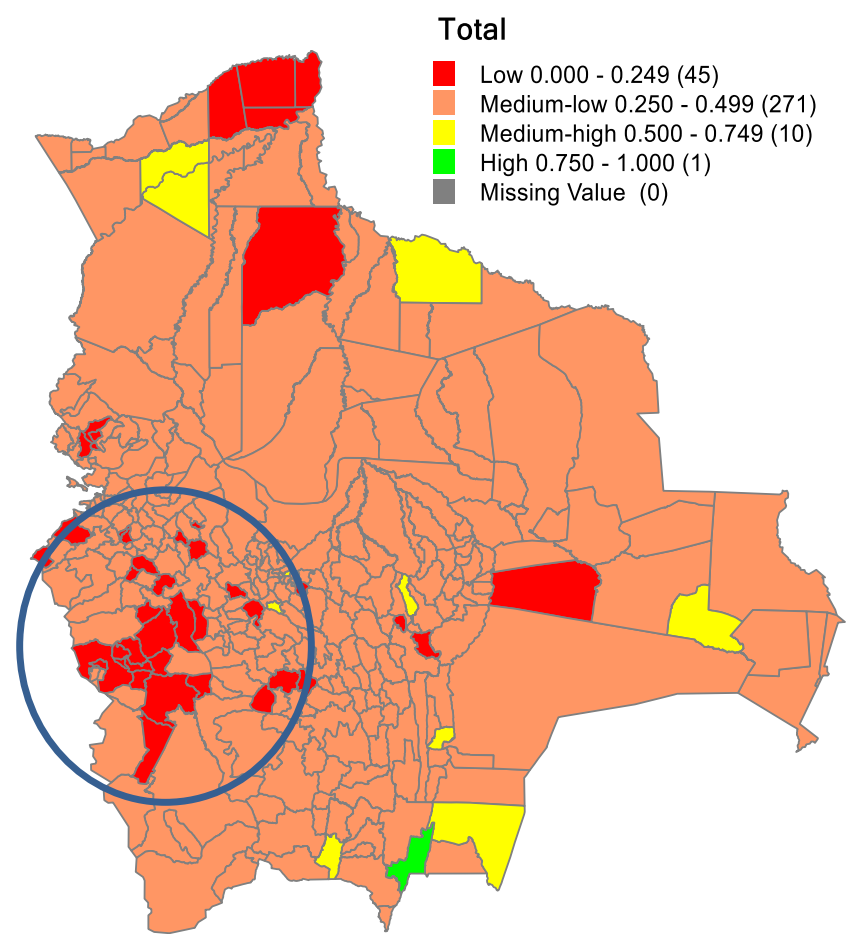

As detailed in Table 9 above, the information for the annual estimation contains complete data sets for each single indicator. Despite the efforts of the current government, the level of wellbeing at subnational levels does not appear to have improved over the years. The common area where the worst WBI values appear remains over the years (blue circle). Moreover, the area appears to grow, since more municipalities get lower WBI values through the period of analysis. The number of municipalities in the low class increased from 18 in 2002 to 45 in 2007. Most (207) of them in 2002 belong to the medium-low class, increasing this number to 271 in 2007, being the predominant class in all years.

Most of the municipalities between 2002 and 2007 have a negative change in their WBI values, according to Figure 14 below. Only 21 ( $6 \%$ of total of municipalities) have a positive change in WBI values. The most remarkable municipality is Carapari, having increased its WBI value in $53 \%$. The social investment achieved in this municipality is also noteworthy, reaching the highest, on average, from 2002 to 2007. Other municipalities such as Ingavi and Nacebe (Santa Rosa del Abuna) also have important changes in their WBI values. What is more, the former have no social investment from 2002 to 2007. In contrast, the monetary efforts aimed at Acasio and Arampampa, reaching USD100 per capita, are not sufficient to observe a positive increase in their WBI values. 
Figure 14. Change in WBI and social investment for 2002-2007

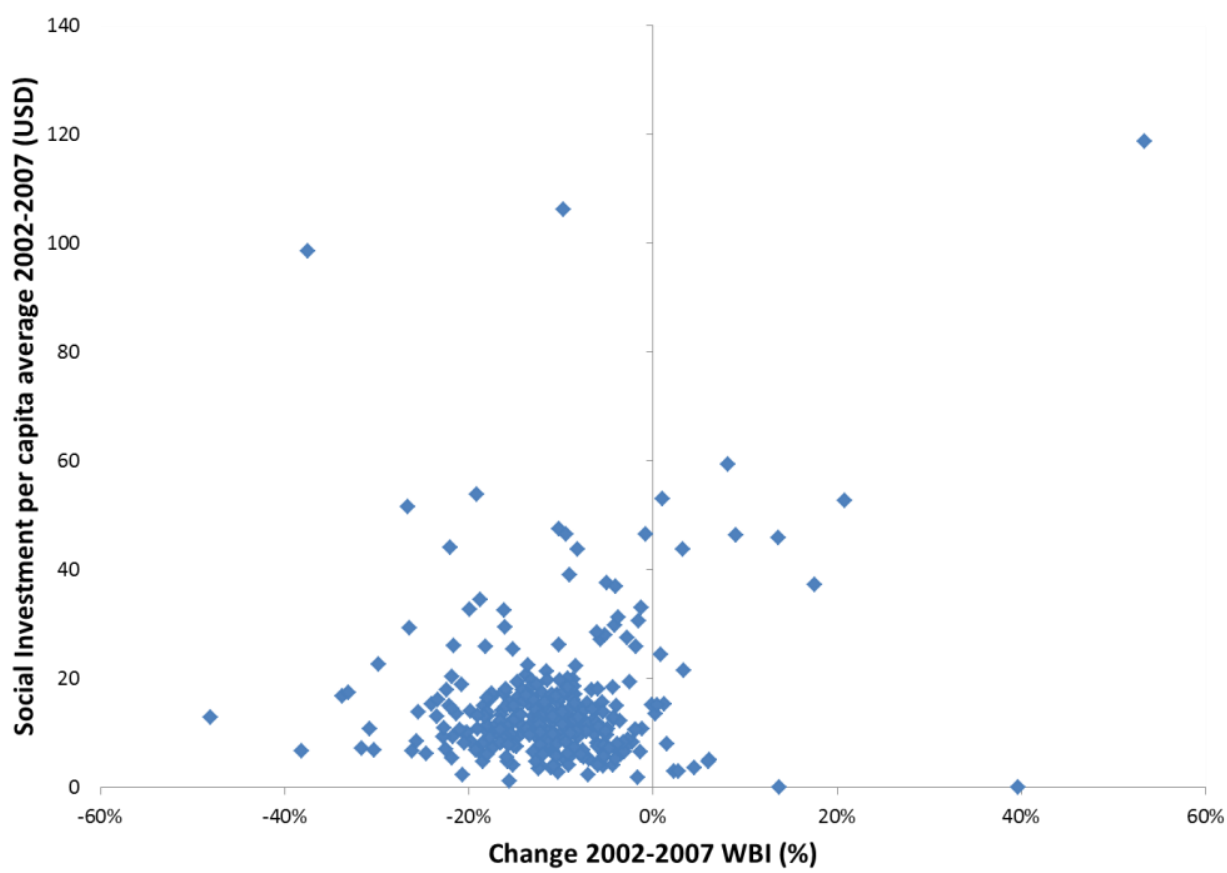

\section{Conclusions and recommendations}

During the last decade, Bolivia has improved most of its economic and social indicators at national level. Real GDP, on average, reached 3.7\%; GDP per capita increased from USD995 in 2000 to USD1,638 in 2010; extreme poverty decreased from $45 \%$ in 2000 to $26 \%$ in 2009 (UDAPE \& World Bank, 2012); and human development via the HDI increased from 0.620 in 2000 to 0.675 in 2012. Despite these achievements, there is still room for improvement, especially in the social arena. The findings in this study reveal the disparities at subnational levels in Bolivia by analyzing the levels and their evolution over time, the identification of the municipalities with the lowest and highest levels of wellbeing, and the identification of the single indicators that contribute most to the wellbeing (WBI) estimation.

Most of the municipalities (286) during the 2000 to 2011 period of analysis are concentrated in the medium-low class (WBI values ranging from 0.25 to 0.49 ) and almost all of the bottom municipalities with low WBI values are located in the west of Bolivia. Only a few municipalities have higher WBI, and, classifying the municipalities by quartiles, the top three municipalities (WBI $=0.925$ average) are far away from the 25 low WBI values-municipalities (WBI $=0.210$ average), revealing the current disparities at subnational levels. The analysis of the periods 2000-2005 and 2006-2011 revealed similar patterns, situating most of the municipalities in the medium-high class; however, the level of wellbeing appears to be reduced between periods. In addition, the worst WBI values remained in both periods (Cruz de Machacamarca, Yunguyo de Litoral, Esmeralda, and Escara). Finally, the annual analysis of WBI values over time suggests again that the level of wellbeing decreased with the passing of time. The common area where the worst WBI values appear remains over the years $(2002,2003,2006$ and 2007). Moreover, the area appears to grow since more municipalities get lower WBI values through the period of analysis. These municipalities are located in the Department of Oruro, and, given the fact that they are located near each other; the government 
should pay attention not only to this area (municipalities of Huachacalla, Escara, Cruz de Machacamarca, Yunguyo de Litoral, Esmeralda and Todos Santos) but also to the other low WBI municipalities.

The current supply of services in the education and health sectors in Bolivia are crucial for wellbeing. For instance, the number of health centers and hospitals per 100,000 population and number of schools, colleges and institutes per 100,000 population resulted in contributing $90 \%$ and $73 \%$ to the WBI estimation. The availability of doctors, nurses and administrative personnel contributes $97 \%$ of its information and the number of teachers and schools and institutes $88 \%$, reflecting the importance of increasing supply of these personnel and infrastructure in the municipalities, considering that only approximately USD3.6 per capita is invested in health at subnational levels. Therefore, having personnel (doctors, nurses and teachers) in the health centers, hospitals and schools, accompanied by social investment in health and education, are key elements to improving wellbeing at subnational levels.

Even though the dimensions applied via the theoretical framework are indicative, and other single indicators can be included; the findings suggest that the social dimension (number of health centers and hospitals per 100,000 population and number of schools, colleges and institutes per 100,000 population) present the worst WBI values for all dimensions, and, from the three dimensions, the material one is the one which contributes all of its information to the WBI estimation.

In terms of social investment, this element result is important when estimating wellbeing. It is important to analyze more deeply the determinants for the municipalities that achieved a positive change in their WBI values from 2002 to 2007 in order to ensure that the most-needed municipalities receive sufficient funds to improve their conditions.

Even though these findings are an important input for further public policy, more evidence and research is required, especially taking into account that new data will be available at the end of 2013, resulting from the national census carried in 2012. Finally, it is imperative that the Government of Bolivia starts to design surveys to assess links between the various dimensions of wellbeing and that this information is used when designing policies in various fields (Stiglitz et al., 2009).

\section{Author}

Jose Antonio Canaviri

UNICEF

acanaviri@unicef.org

\section{Publishing Timeline}

Received 8 August 2014

Accepted 13 November 2015

Published 14 May 2016

\section{References}

Alkire, S. (2011). Multidimensional poverty and its discontents (OPHI Working Paper No. 46). http://dx.doi.org/10.2139/ssrn.2118543

Berenger, V., \& Verdier-Couchane, A. (2007). Multidimensional measures of wellbeing: Standard of living and quality of life across countries. World Development, 35(7), 1259-1276. http://dx.doi.org/10.1016/j.worlddev.2006.10.011 
Booysen, F. (2002). An overview and evaluation of composite indices of development. Social Indicators Research, 59(2), 115-151. http://dx.doi.org/10.1023/A:1016275505152

Bras, L., \& Menezes, J. (2007). Improving cluster-based missing value estimation of DNA microarray data. Biomolecular Engineering, 24(1), 273-282. http://dx.doi.org/10.1016/j.bioeng.2007.04.003

Cuenca, E., Rodriguez, J., \& Navarro, M. (2010). The features of development in the Pacific countries of the African, Caribbean and Pacific group. Social Indicators Research, 99(3), 469-485. http://dx.doi.org/10.1007/s11205-010-9594-7

Economic and Social Policy Analysis Bureau (2009). Municipal infrastructure. http://udape.gob.bo/index.php?option=com wrapper\&view=wrapper\&Itemid=108

Economic and Social Policy Analysis Bureau (2010a). Municipal social investment towards MDG. http://udape.gob.bo/index.php?option=com_wrapper\&view=wrapper\&Itemid=127

Economic and Social Policy Analysis Bureau (2010b). Dossier of economic and social statistics. http://www.udape.gob.bo/portales_html/dossierweb2012/doss0709.htm

Economic and Social Policy Analysis Bureau \& United Nations Children's Emergency Fund (2005). Bolivia. Equity and children's rights. Municipal Development Index for children and adolescents. La Paz, Bolivia: UNICEF.

Economic and Social Policy Analysis Bureau \& United Nations Children's Emergency Fund (2008). Bolivia. Equity and children's rights. Municipal Development Index for children and adolescents. La Paz, Bolivia: UNICEF.

Economic and Social Policy Analysis Bureau \& World Bank (2012). Equal opportunities for children and youth of Bolivia. http://www.udape.gob.bo/portales html/docsociales/pdfoportunidades.pdf

Epley, D. (2008). A method of assembling cross-sectional indicators into a community quality of life. Social Indicators Research, 88(2), 281-296. http://dx.doi.org/10.1007/s11205-007-9190-7

Heshmati, A. (2008). Measurement and analysis of child wellbeing in middle and high income countries. The European Journal of Comparative Economics, 5(2), 227-286.

Ivanovic, B. (1963). Classification of underdeveloped areas according to level of economic development. International Arts and Sciences Press, Eastern European Economics, 2(1), 1-2. http://dx.doi.org/10.1080/00128775.1963.11647849

Ministry of Development and Planning (2006). National Development Plan. Murias, P., Martinez, F., \& De Miguel, C. (2006). An economic wellbeing index for the Spanish provinces: A data envelopment analysis approach. Social Indicators Research, 77(3), 395-417. http://dx.doi.org/10.1007/s11205-005-2613-4

Nardo, M., \& Saisana, M. (2008). OECD/JRC handbook on constructing composite indicators. Putting theory into practice. https://www.oecd.org/std/42495745.pdf

National Statistics Institute (2013). Demographic statistics. http://www.ine.gob.bo/indice/visualizador.aspx?ah=PC2030905.HTM

Nieboer, A., Lindenberg, S., Boomsma, A., \& Bruggen, A. (2005). Dimensions of wellbeing and their measurement: The SPF-IL scale. Social Indicators Research, 73(3), 313-353. http://dx.doi.org/10.1007/s11205$\underline{004-0988-2}$

Ocampo, M., \& Foronda, C. (2007). Study of quality of life in Bolivia: Methodology and measurement. Investigacion y Desarrollo, 7(1), 25-40.

Organisation for Economic Co-operation and Development (2008). Handbook on constructing composite indicators: Methodology and Guide. Paris, France: Organisation for Economic Co-operation and Development.

Organisation for Economic Co-operation and Development (2011). Society at a glance 2011: OECD social indicators. http://www.oecd.org/social/soc/societyataglance2011.htm

Pena, B. (1977). Problems of measuring welfare and related concepts. An application to the Spanish case. Madrid, Spain: National Statistical Institute.

Pena, B. (2009). The measurement of social welfare: A critical review. Estudios de economía aplicada, 27(2), 299-324. 
Ravallion, M. (2010). Mashup indices of development. (Policy Research Working Paper 5432). http://dx.doi.org/10.1596/1813-9450-5432

Ravallion, M. (2012). Troubling tradeoffs in the Human Development Index. Journal of Development Economics, 99(2), 201-209. http://dx.doi.org/10.1016/j.jdeveco.2012.01.003

Rodriguez, J. (2010). An index of child health in the least developed countries (LDCs) of Africa. Social Indicators Research, 105(3), 309-322. http://dx.doi.org/10.1007/s11205-010-9778-1

Seligson, J., Huebner, E., \& Valois, R. (2005). An investigation of a brief life satisfaction scale with elementary school children. Social Indicators Research, 73(3), 355-374. http://dx.doi.org/10.1007/s11205-004-2011-3

Somarriba, N. (2008). Aproximacion a la medicion de la calidad de vida en la Union Europea (Doctoral dissertation, Universidad de Valladolid). http://www.eumed.net/tesis/2010/mnsa/index.htm

Somarriba, N., \& Pena, B. (2009). Measuring the quality of life in Europe: The role of subjective information. Estudios de Economia Aplicada, 27(2), 373-396.

Somarriba, N., \& Pena, B. (2009). Synthetic indicators of quality of life in Europe. Social Indicators Research, 94(1), 115-133. http://dx.doi.org/10.1007/s11205-008-9356-y

Stiglitz, E., Sen, A., \& Fitoussi, J. P. (2009). Report by the Commission on the Measurement of Economic Performance and Social Progress. http://www.stiglitz-sen-fitoussi.fr/documents/rapport anglais.pdf

Torras, M. (2008). The subjectivity inherent in objective measures of wellbeing. Journal of Happiness Studies, 9(4), 475-487. http://dx.doi.org/10.1007/s10902-007-9084-z

Troyanskaya, O., Cantor, M., Sherlock, G., Brown, P., Hastie, T., Tibshirani, R., . . \& A Altman, B. (2001). Missing value estimation methods for DNA microarrays. Bioinformatics, 17(6), 520-525. http://dx.doi.org/10.1093/bioinformatics/17.6.520

United Nations Development Programme (2013). Human Development Report 2013. The Rise of the South: Human Progress in a Diverse World. http://hdr.undp.org/en/2013-report

United Nations Children's Emergency Fund (2010). Situation analysis of children and women in Bolivia. http://www.unicef.org/bolivia/UNICEF_Bolivia__Por_los_ninos_ninas_y_adolescentes_de_Bolivia(1).pdf

United States Agency for International Development (2008). Classification of municipalities in Bolivia by criteria of Health: Guidelines for municipal public investment. La Paz, Bolivia: Artes Gráficas Sagitario.

White, S. (2009). Analyzing wellbeing: A framework for development practice (WeD Working Paper No. 09). http://opus.bath.ac.uk/13944/1/WeDWP_09_44.pdf

Zarzosa, P. (2009). Estimación de la pobreza en las comunidades autónomas españolas, mediante la distancia DP2 de Pena. Estudios de Economia Aplicada, 27(2), 397-416.

Zarzosa, P., \& Somarriba, N. (2013). An assessment of social welfare in Spain: Territorial analysis using a synthetic welfare indicator. Social Indicators Research, 111(1), 1-23. http://dx.doi.org/10.1007/s11205-012$\underline{0005-0}$ 


\section{Appendix 1}

\section{Imputation of Missing Data}

Most of the time, data sets lack complete information on the variables of interest. In order to fill empty spaces in a data matrix, imputation techniques are needed. According to Nardo and Saisana (2008), there are three methods to deal with missing data: case deletion, single imputation, and multiple imputations. The first ignores possible differences between complete and incomplete samples and may produce biased estimates; moreover, the standard errors may be larger for samples that are small. Little and Rubin (2002) establish that as a rule of thumb, if a variable has more than $5 \%$ missing, values cases are not deleted (cited in Nardo \& Saisana (2008)).

The last column of Table 1 shows there are missing data for most of the indicators in the study. The highest rates are for the social investment indicators, and for all of the data sets, the values reach less than $5 \%$ and thus the missing values do not represent a serious threat. As mentioned before, an imputation method was chosen. According to the OECD (2008), there are "implicit" and "explicit" modelings when treating missing data. Implicit modeling includes hot deck imputation, substitution and cold deck imputation; explicit modeling includes unconditional mean/median/mode imputation, regression imputation, and expectation maximization imputation.

Imputation values for all the missing data were estimated using the hot deck imputation method. In this method, the missing data is filled with individual data drawn from similar responding units. Implicit modeling uses an algorithm which uses implied underlying assumptions which need to be verified, in the sense that they are reasonable and fit for the issue under consideration (OECD, 2008). The algorithm used was "knnimpute" in MATLAB software. The algorithm was applied to the variables for which information was available for various years. For instance, data for children with diarrhoea are available from 2000 to 2009 (see Table 1 above). If a value is missed in that range of data, the algorithm searches within that range of values and calculates the most similar values.

KNN imputation calculates a weighted Euclidean distance $d_{i k}$ between the target value $i$ and each candidate value $k$, assuming $r$ contains the missing indicator matrix, using the following expression (Bras \& Menezes, 2007):

$$
d_{i k}=\sqrt{\frac{\sum_{j=1}^{n} r_{i j} r_{j k}\left(x_{k j}-x_{i j}\right)^{2}}{\sum_{j=1}^{n} r_{i j} r_{j k}}}
$$

where $r_{i j}$ is the element in the $i$ row and $j$ column of the missing indicator matrix $r$. The missing entry $j$ of target value $i$ is then estimated by the weighted average of the expression values of the $K$ with most similar values to the $j$ values:

$$
\hat{y}_{i j}=\sum_{k=1}^{K} w_{i k} x_{k j}
$$

where $w_{i k}$ is the weight for the $k$ neighbor value of target value $i$ normalized by the sum of the inverse weighted Euclidean distance for all $K$ neighbors:

$$
w_{i k}=\frac{\frac{1}{d_{i k}}}{\frac{\sum_{k=1}^{K} 1}{d_{i k}}}
$$

This method was proposed initially by Troyanskaya et al. (2001). According to the authors, using this method compared to others such as Singular Value Decomposition (SDV) - using a variety of 
parameter settings and over different real data sets, and assessing the robustness of the imputation

methods to the amount of missing data over the range of $1-20 \%$ missing values -provides a more robust and sensitive method for missing value estimation. 
Appendix 2

WBI values estimated by DP2 for the period 2000-2011

\begin{tabular}{|c|c|c|c|c|c|c|c|c|c|}
\hline Municipality & $\begin{array}{c}\text { WBI } \\
\text { Material }\end{array}$ & $\begin{array}{c}\text { WBI } \\
\text { Social }\end{array}$ & $\begin{array}{c}\text { WBI } \\
\text { Human }\end{array}$ & $\begin{array}{l}\text { WBI } \\
\text { Total }\end{array}$ & Municipality & $\begin{array}{c}\text { WBI } \\
\text { Material }\end{array}$ & $\begin{array}{c}\text { WBI } \\
\text { Social }\end{array}$ & $\begin{array}{c}\text { WBI } \\
\text { Human }\end{array}$ & $\begin{array}{l}\text { WBI } \\
\text { Total }\end{array}$ \\
\hline Sucre & 0.5463 & 0.2807 & 0.7068 & 0.6373 & Santiago de & \multirow{2}{*}{0.0560} & \multirow{2}{*}{0.0360} & \multirow{2}{*}{0.5306} & \multirow{2}{*}{0.2583} \\
\hline Yotala & 0.2148 & 0.0339 & 0.6486 & 0.3731 & Callapa & & & & \\
\hline Poroma & 0.0974 & 0.0503 & 0.6241 & 0.3204 & Puerto Acosta & 0.0882 & 0.0878 & 0.6346 & 0.3363 \\
\hline Azurduy & 0.1241 & 0.0334 & 0.6448 & 0.3333 & Moco Moco & 0.1467 & 0.0616 & 0.7198 & 0.3856 \\
\hline Tarvita & 0.1604 & 0.0391 & 0.6253 & 0.3428 & Carabuco & 0.0958 & 0.0484 & 0.5942 & 0.3065 \\
\hline Zudañez & 0.1527 & 0.0240 & 0.5853 & 0.3167 & Chuma & 0.0826 & 0.0451 & 0.5037 & 0.2620 \\
\hline Presto & 0.1035 & 0.0227 & 0.5392 & 0.2764 & Ayata & 0.1087 & 0.0293 & 0.6222 & 0.3158 \\
\hline Mojocoya & 0.0958 & 0.0232 & 0.5953 & 0.2967 & Aucapata & 0.1123 & 0.0185 & 0.7286 & 0.3571 \\
\hline Icla & 0.2579 & 0.0211 & 0.5964 & 0.3643 & Sorata & 0.0889 & 0.0645 & 0.5821 & 0.3052 \\
\hline Padilla & 0.1619 & 0.0466 & 0.6046 & 0.3379 & Guanay & 0.2478 & 0.0336 & 0.7194 & 0.4164 \\
\hline Tomina & 0.1844 & 0.0204 & 0.5778 & 0.3254 & Tacacoma & 0.1478 & 0.0179 & 0.6646 & 0.3451 \\
\hline Sopachuy & 0.1387 & 0.0186 & 0.5651 & 0.3002 & Quiabaya & 0.1243 & 0.0080 & 0.6703 & 0.3336 \\
\hline Villa Alcalá & 0.1769 & 0.0085 & 0.4529 & 0.2655 & Combaya & 0.1298 & 0.0114 & 0.5797 & 0.2996 \\
\hline El Villar & 0.0944 & 0.0140 & 0.5100 & 0.2569 & Tipuani & 0.2141 & 0.0126 & 0.6392 & 0.3603 \\
\hline Monteagudo & 0.1700 & 0.0714 & 0.5907 & 0.3457 & Mapiri & 0.1624 & 0.0185 & 0.8667 & 0.4356 \\
\hline Huacareta & 0.1238 & 0.0371 & 0.6742 & 0.3470 & Teoponte & 0.1343 & 0.0284 & 0.8103 & 0.4044 \\
\hline Tarabuco & 0.1898 & 0.0528 & 0.6703 & 0.3794 & Apolo & 0.0418 & 0.0611 & 0.6983 & 0.3324 \\
\hline Yamparaez & 0.2153 & 0.0267 & 0.5615 & 0.3342 & Pelechuco & 0.3460 & 0.0192 & 0.5837 & 0.3952 \\
\hline Camargo & 0.2593 & 0.0486 & 0.6148 & 0.3838 & Viacha & 0.2149 & 0.0835 & 0.6242 & 0.3833 \\
\hline San Lucas & 0.1404 & 0.0940 & 0.6285 & 0.3582 & Guaqui & 0.1403 & 0.0185 & 0.5421 & 0.2913 \\
\hline Incahuasi & 0.1072 & 0.0505 & 0.5914 & 0.3110 & Tiahuanacu & 0.1576 & 0.0284 & 0.6207 & 0.3354 \\
\hline Villa Serrano & 0.2712 & 0.0422 & 0.5939 & 0.3775 & Desaguadero & 0.1748 & 0.0128 & 0.7937 & 0.4081 \\
\hline $\begin{array}{l}\text { Camataqui } \\
\text { (Villa Abecia) }\end{array}$ & 0.1984 & 0.0112 & 0.5284 & 0.3070 & $\begin{array}{l}\text { San Andres } \\
\text { de Machaca }\end{array}$ & 0.1219 & 0.0292 & 0.6029 & 0.3133 \\
\hline Culpina & 0.2084 & 0.0522 & 0.7212 & 0.4081 & Jesus de & 013 & 00505 & 06585 & 03519 \\
\hline Las Carreras & 0.2252 & 0.0161 & 0.6033 & 0.3514 & Machaca & 0.1 & & 0.6 & \\
\hline Villa Vaca & \multirow{2}{*}{0.1642} & \multirow{2}{*}{0.0347} & \multirow{2}{*}{0.5643} & \multirow{2}{*}{0.3172} & Taraco & 0.0605 & 0.0180 & 0.6051 & 0.2838 \\
\hline Guzman & & & & & Luribay & 0.2194 & 0.0313 & 0.6838 & 0.3887 \\
\hline Huacaya & 0.1643 & 0.0085 & 0.5562 & 0.3032 & Sapahaqui & 0.1038 & 0.0410 & 0.5326 & 0.2813 \\
\hline Macharetí & 0.1889 & 0.0237 & 0.5612 & 0.3218 & Yaco & 0.0970 & 0.0249 & 0.6114 & 0.3046 \\
\hline La Paz & 1.0000 & 0.7770 & 0.6338 & 1.0000 & Malla & 0.0884 & 0.0106 & 0.4486 & 0.2274 \\
\hline Palca & 0.0852 & 0.0444 & 0.6301 & 0.3154 & Cairoma & 0.1029 & 0.0348 & 0.6097 & 0.3104 \\
\hline Mecapaca & 0.1149 & 0.0305 & 0.6197 & 0.3179 & Inquisivi & 0.0709 & 0.0720 & 0.5547 & 0.2893 \\
\hline Achocalla & 0.1007 & 0.0253 & 0.5610 & 0.2853 & Quime & 0.1178 & 0.0161 & 0.6105 & 0.3094 \\
\hline El Alto & 0.4593 & 0.4514 & 0.6063 & 0.6287 & Cajuata & 0.1750 & 0.0199 & 0.8043 & 0.4155 \\
\hline Achacachi & 0.1495 & 0.1460 & 0.6047 & 0.3733 & Colquiri & 0.0716 & 0.0610 & 0.7241 & 0.3556 \\
\hline Ancoraimes & 0.1417 & 0.0429 & 0.6540 & 0.3484 & Ichoca & 0.0481 & 0.0273 & 0.5459 & 0.2578 \\
\hline Coro Coro & 0.0843 & 0.0372 & 0.5318 & 0.2711 & Licoma & \multirow{2}{*}{0.1225} & \multirow{2}{*}{0.0072} & \multirow{2}{*}{0.5398} & \multirow{2}{*}{0.2782} \\
\hline Caquiaviri & 0.1000 & 0.0524 & 0.6030 & 0.3136 & Pampa & & & & \\
\hline Calacoto & 0.1131 & 0.0503 & 0.5576 & 0.2993 & Chulumani & 0.2300 & 0.0349 & 0.7124 & 0.4065 \\
\hline Comanche & 0.1282 & 0.0165 & 0.6285 & 0.3214 & Irupana & 0.1606 & 0.0463 & 0.7097 & 0.3809 \\
\hline Charaña & 0.1696 & 0.0142 & 0.6308 & 0.3388 & Yanacachi & 0.2375 & 0.0148 & 0.6028 & 0.3558 \\
\hline Waldo & \multirow{2}{*}{0.1341} & \multirow{2}{*}{0.0058} & \multirow{2}{*}{0.7023} & \multirow{2}{*}{0.3502} & Palos Blancos & 0.1600 & 0.0501 & 0.8229 & 0.4293 \\
\hline Ballivian & & & & & La Asunta & 0.1058 & 0.0670 & 0.7858 & 0.3980 \\
\hline Nazacara de & \multirow{2}{*}{0.1178} & \multirow{2}{*}{0.0015} & \multirow{2}{*}{1.0000} & \multirow{2}{*}{0.4654} & Pucarani & 0.1033 & 0.0617 & 0.5485 & 0.2961 \\
\hline Pacajes & & & & & Laja & 0.1027 & 0.0511 & 0.5979 & 0.3121 \\
\hline
\end{tabular}




\begin{tabular}{|c|c|c|c|c|c|c|c|c|c|}
\hline Municipality & $\begin{array}{c}\text { WBI } \\
\text { Material }\end{array}$ & $\begin{array}{l}\text { WBI } \\
\text { Social }\end{array}$ & $\begin{array}{c}\text { WBI } \\
\text { Human }\end{array}$ & $\begin{array}{c}\text { WBI } \\
\text { Total }\end{array}$ & Municipality & $\begin{array}{c}\text { WBI } \\
\text { Material }\end{array}$ & $\begin{array}{l}\text { WBI } \\
\text { Social }\end{array}$ & $\begin{array}{c}\text { WBI } \\
\text { Human }\end{array}$ & $\begin{array}{c}\text { WBI } \\
\text { Total }\end{array}$ \\
\hline Batallas & 0.1025 & 0.0511 & 0.5499 & 0.2920 & Sipe Sipe & 0.2139 & 0.0429 & 0.6105 & 0.3606 \\
\hline Puerto Pérez & 0.0764 & 0.0199 & 0.5044 & 0.2494 & Tiquipaya & 0.2347 & 0.0496 & 0.5747 & 0.3572 \\
\hline Sica Sica & 0.0931 & 0.0582 & 0.5355 & 0.2850 & Vinto & 0.2053 & 0.0362 & 0.5716 & 0.3381 \\
\hline Umala & 0.1249 & 0.0264 & 0.5398 & 0.2871 & Colcapirhua & 0.2606 & 0.0210 & 0.4742 & 0.3146 \\
\hline Ayo Ayo & 0.0741 & 0.0259 & 0.6144 & 0.2966 & Sacaba & 0.2233 & 0.0910 & 0.5452 & 0.3571 \\
\hline Calamarca & 0.1161 & 0.0250 & 0.5986 & 0.3074 & Colomi & 0.2424 & 0.0290 & 0.6615 & 0.3881 \\
\hline Patacamaya & 0.1678 & 0.0416 & 0.5830 & 0.3293 & Villa Tunari & 0.1803 & 0.1362 & 0.6380 & 0.3961 \\
\hline Colquencha & 0.0941 & 0.0149 & 0.5350 & 0.2675 & Tapacari & 0.0918 & 0.1222 & 0.5731 & 0.3262 \\
\hline Collana & 0.1935 & 0.0050 & 0.4379 & 0.2647 & Totora & 0.1013 & 0.0348 & 0.5960 & 0.3040 \\
\hline Coroico & 0.2134 & 0.0336 & 0.6815 & 0.3862 & Pojo & 0.2044 & 0.0305 & 0.5331 & 0.3194 \\
\hline Coripata & 0.2138 & 0.0248 & 0.6862 & 0.3847 & Pocona & 0.1012 & 0.0404 & 0.6098 & 0.3120 \\
\hline Ixiamas & 0.1912 & 0.0262 & 0.6424 & 0.3575 & Chimoré & 0.1758 & 0.0407 & 0.5790 & 0.3306 \\
\hline $\begin{array}{l}\text { San Buena } \\
\text { Ventura }\end{array}$ & 0.2126 & 0.0198 & 0.7279 & 0.3994 & $\begin{array}{l}\text { Puerto } \\
\text { Villarroel }\end{array}$ & 0.1778 & 0.0767 & 0.6483 & 0.3750 \\
\hline $\begin{array}{l}\text { Gral. Juan } \\
\text { José Perez }\end{array}$ & 0.2057 & 0.0313 & 0.5262 & 0.3173 & $\begin{array}{l}\text { Entre Rios } \\
\text { (Bulo Bulo) }\end{array}$ & 0.1734 & 0.0334 & 0.6359 & 0.3503 \\
\hline Curva & 0.1117 & 0.0085 & 0.4852 & 0.2516 & Mizque & 0.1898 & 0.0933 & 0.4687 & 0.3121 \\
\hline Copacabana & 0.1411 & 0.0304 & 0.6245 & 0.3308 & Vila Vila & 0.1450 & 0.0171 & 0.4440 & 0.2519 \\
\hline San Pedro de & & & & & Alalay & 0.1535 & 0.0199 & 0.4085 & 0.2418 \\
\hline Tiquina & 0.1114 & 0.0149 & 0.4908 & 0.2564 & Punata & 0.3127 & 0.0463 & 0.6761 & 0.4307 \\
\hline Tito Yupanqui & 0.0685 & 0.0058 & 0.4849 & 0.2322 & Villa Rivero & 0.1607 & 0.0136 & 0.5724 & 0.3104 \\
\hline San Pedro de & & & & & San Benito & 0.2603 & 0.0234 & 0.5396 & 0.3426 \\
\hline Curahuara & 0.0878 & 0.0287 & 0.5508 & 0.2771 & Tacachi & 0.0931 & 0.0026 & 0.4277 & 0.2175 \\
\hline Papel Pampa & 0.1152 & 0.0236 & 0.6542 & 0.3296 & Cuchumuela & 0.1673 & 0.0077 & 0.5800 & 0.3140 \\
\hline Chacarilla & 0.0206 & 0.0080 & 0.5267 & 0.2304 & Bolivar & 0.1406 & 0.0366 & 0.5474 & 0.3010 \\
\hline Santiago de & & & & & & 0.2391 & 0.0666 & 0.6229 & 0.3860 \\
\hline Machaca & 0.2105 & 0.0179 & 0.5351 & 0.3176 & Oruro & 0.4258 & 0.2235 & 0.7752 & 0.5918 \\
\hline Catacora & 0.1572 & 0.0050 & 0.3973 & 0.2326 & Caracollo & 0.1592 & 0.0496 & 0.6666 & 0.3637 \\
\hline Caranavi & 0.1851 & 0.1764 & 0.6450 & 0.4175 & El Choro & 0.0000 & 0.0098 & 0.5853 & 0.2469 \\
\hline Cochabamba & 0.6545 & 0.5580 & 0.6874 & 0.7879 & Paria & 0.1673 & 0.0503 & 0.6337 & 0.3537 \\
\hline Aiquile & 0.1411 & 0.0640 & 0.5176 & 0.3000 & Challapata & 0.1513 & 0.0609 & 0.5702 & 0.3249 \\
\hline Pasorapa & 0.1398 & 0.0157 & 0.4406 & 0.2478 & Santuario de & & & & \\
\hline Omereque & 0.1294 & 0.0213 & 0.6419 & 0.3294 & Quillacas & 0.1100 & 0.0085 & 0.4594 & 0.2401 \\
\hline Ayopaya & 0.0980 & 0.0925 & 0.6314 & 0.3410 & Corque & 0.0762 & 0.0267 & 0.6186 & 0.2996 \\
\hline Morochata & 0.0983 & 0.0973 & 0.5157 & 0.2949 & Choque Cota & 0.1174 & 0.0086 & 0.4967 & 0.2588 \\
\hline Tarata & 0.2233 & 0.0396 & 0.6841 & 0.3939 & Curahuara de & & & & 35 \\
\hline Anzaldo & 0.1233 & 0.0536 & 0.5908 & 0.3188 & Carangas & & & & \\
\hline Arbieto & 0.2916 & 0.0192 & 0.6511 & 0.4004 & Turco & 0.2331 & 0.0160 & 0.6542 & 0.3759 \\
\hline Sacabamba & 0.1533 & 0.0279 & 0.5983 & 0.3240 & Huachacalla & 0.1707 & 0.0050 & 0.3496 & 0.2185 \\
\hline Arani & 0.2190 & 0.0221 & 0.6256 & 0.3605 & Escara & 0.1180 & 0.0015 & 0.3011 & 0.1748 \\
\hline Vacas & 0.1050 & 0.0255 & 0.4466 & 0.2396 & Cruz de & & & & \\
\hline Arque & 0.0980 & 0.0393 & 0.5345 & 0.2789 & Machacamarc & 0.0015 & 0.0000 & 0.0000 & 0.0000 \\
\hline Tacopaya & 0.1715 & 0.0392 & 0.4804 & 0.2872 & a & & & & \\
\hline Capinota & 0.2004 & 0.0320 & 0.6869 & 0.3823 & Yunguyo de & & & & \\
\hline Santivañez & 0.1858 & 0.0182 & 0.5005 & 0.2929 & Litoral & & & & \\
\hline Sicaya & 0.0989 & 0.0049 & 0.7591 & 0.3586 & Esmeralda & 0.0677 & 0.0014 & 0.2948 & 0.1510 \\
\hline Cliza & 0.2771 & 0.0258 & 0.6201 & 0.3841 & Poopó & 0.1146 & 0.0098 & 0.5776 & 0.2918 \\
\hline Toko & 0.1674 & 0.0104 & 0.6158 & 0.3300 & Pazña & 0.1980 & 0.0169 & 0.6380 & 0.3548 \\
\hline Tolata & 0.2310 & 0.0063 & 0.5824 & 0.3412 & Antequera & 0.1153 & 0.0078 & 0.5726 & 0.2891 \\
\hline Quillacollo & 0.3108 & 0.0985 & 0.5910 & 0.4159 & Huanuni & 0.2268 & 0.0295 & 0.7580 & 0.4219 \\
\hline
\end{tabular}




\begin{tabular}{|c|c|c|c|c|c|c|c|c|c|}
\hline Municipality & $\begin{array}{c}\text { WBI } \\
\text { Material }\end{array}$ & $\begin{array}{c}\text { WBI } \\
\text { Social }\end{array}$ & $\begin{array}{c}\text { WBI } \\
\text { Human }\end{array}$ & $\begin{array}{l}\text { WBI } \\
\text { total }\end{array}$ & Municipality & $\begin{array}{c}\text { WBI } \\
\text { Material }\end{array}$ & $\begin{array}{c}\text { WBI } \\
\text { Social }\end{array}$ & $\begin{array}{c}\text { WBI } \\
\text { Human }\end{array}$ & $\begin{array}{l}\text { WBI } \\
\text { total }\end{array}$ \\
\hline \multirow{2}{*}{$\begin{array}{l}\text { Machacamarc } \\
\text { a }\end{array}$} & \multirow{2}{*}{0.2216} & \multirow{2}{*}{0.0114} & \multirow{2}{*}{0.6258} & \multirow{2}{*}{0.3573} & Puna & 0.0782 & 0.1360 & 0.5938 & 0.3348 \\
\hline & & & & & Caiza "D" & 0.1327 & 0.0343 & 0.6427 & 0.3364 \\
\hline Salinas G. de & \multirow{2}{*}{0.0747} & \multirow{2}{*}{0.0328} & \multirow{2}{*}{0.6505} & \multirow{2}{*}{0.3147} & Uyuni & 0.2277 & 0.0635 & 0.7264 & 0.4230 \\
\hline Mendoza & & & & & Tomave & 0.1419 & 0.0608 & 0.5383 & 0.3077 \\
\hline Pampa & \multirow{2}{*}{0.0570} & \multirow{2}{*}{0.0066} & \multirow{2}{*}{0.5739} & \multirow{2}{*}{0.2647} & Porco & 0.1583 & 0.0121 & 0.7658 & 0.3893 \\
\hline Aullagas & & & & & Arampampa & 0.5031 & 0.0242 & 0.7172 & 0.5187 \\
\hline Sabaya & 0.0901 & 0.0124 & 0.4630 & 0.2348 & Acasio & 0.4066 & 0.0214 & 0.7045 & 0.4718 \\
\hline Coipasa & 0.0634 & 0.0021 & 0.6500 & 0.2973 & Llica & 0.1288 & 0.0233 & 0.7297 & 0.3665 \\
\hline Chipaya & 0.0744 & 0.0034 & 0.7308 & 0.3360 & Tahua & 0.0438 & 0.0115 & 0.4403 & 0.2056 \\
\hline Toledo & 0.0884 & 0.0182 & 0.6616 & 0.3191 & Villazón & 0.3392 & 0.0678 & 0.7074 & 0.4637 \\
\hline Eucaliptus & 0.2267 & 0.0115 & 0.6151 & 0.3551 & San Agustín & 0.1982 & 0.0078 & 0.6498 & 0.3560 \\
\hline Andamarca & 0.1724 & 0.0167 & 0.6088 & 0.3318 & Tarija & 0.4017 & 0.2524 & 0.7274 & 0.5736 \\
\hline Belén de & \multirow{2}{*}{0.0526} & \multirow{2}{*}{0.0049} & \multirow{2}{*}{0.6632} & \multirow{2}{*}{0.2993} & Padcaya & 0.2850 & 0.0902 & 0.5735 & 0.3944 \\
\hline Andamarca & & & & & Bermejo & 0.4036 & 0.0395 & 0.6270 & 0.4457 \\
\hline Totora & 0.0696 & 0.0290 & 0.6704 & 0.3194 & Yacuiba & 0.3291 & 0.1034 & 0.5108 & 0.3922 \\
\hline Santiago de & \multirow{2}{*}{0.0665} & & & & Carapari & 0.6247 & 0.0411 & 0.7316 & 0.5826 \\
\hline Huari & & 0.0247 & 0.4795 & 0.2368 & Villamontes & 0.4294 & 0.0661 & 0.7644 & 0.5246 \\
\hline La Rivera & 0.1026 & 0.0015 & 0.4703 & 0.2387 & Uriondo & 0.2095 & 0.0400 & 0.7268 & 0.4059 \\
\hline Todos Santos & 0.0431 & 0.0029 & 0.3515 & 0.1649 & Yunchara & 0.3915 & 0.0334 & 0.6606 & 0.4521 \\
\hline Carangas & 0.0370 & 0.0021 & 0.5338 & 0.2378 & San Lorenzo & 0.3412 & 0.0741 & 0.6001 & 0.4225 \\
\hline Huayllamarca & 0.1880 & 0.0207 & 0.6037 & 0.3379 & El Puente & 0.3718 & 0.0478 & 0.6810 & 0.4582 \\
\hline Potosí & 0.4357 & 0.2089 & 0.7561 & 0.5821 & Entre Ríos & 0.3437 & 0.0857 & 0.6780 & 0.4607 \\
\hline Tinguipaya & 0.1522 & 0.0854 & 0.6334 & 0.3616 & Santa Cruz de & & & 6484 & 0915 \\
\hline Yocalla & 0.1728 & 0.0276 & 0.6229 & 0.3423 & la Sierra & 2 & 0 & 0.64 & 5 \\
\hline Urmiri & 0.0974 & 0.0056 & 0.5490 & 0.2709 & Cotoca & 0.2562 & 0.0456 & 0.6503 & 0.3960 \\
\hline Uncia & 0.1836 & 0.0617 & 0.6336 & 0.3652 & Ayacucho & 0.2906 & 0.0327 & 0.5379 & 0.3584 \\
\hline Chayanta & 0.1619 & 0.0396 & 0.6550 & 0.3560 & La Guardia & 0.2744 & 0.0433 & 0.6260 & 0.3926 \\
\hline Llallagua & 0.2777 & 0.0509 & 0.6343 & 0.4006 & El Torno & 0.2140 & 0.0628 & 0.5989 & 0.3640 \\
\hline Betanzos & 0.0885 & 0.0942 & 0.6298 & 0.3370 & Warnes & 0.2787 & 0.0698 & 0.7128 & 0.4414 \\
\hline Chaqui & 0.0587 & 0.0297 & 0.5904 & 0.2818 & Okinawa 1 & 0.2752 & 0.0177 & 0.5982 & 0.3709 \\
\hline Tacobamba & 0.0197 & 0.0452 & 0.5154 & 0.2405 & San Ignacio & 0.2109 & 0.1061 & 0.6176 & 0.3881 \\
\hline Colquechaca & 0.0725 & 0.0917 & 0.6485 & 0.3370 & San Miguel & 0.1703 & 0.0340 & 0.5189 & 0.3006 \\
\hline Ravelo & 0.0968 & 0.0561 & 0.5875 & 0.3073 & San Rafael & 0.1098 & 0.0100 & 0.4894 & 0.2531 \\
\hline Pocoata & 0.1262 & 0.0829 & 0.6770 & 0.3679 & Buena Vista & 0.1778 & 0.0375 & 0.5873 & 0.3336 \\
\hline Ocurí & 0.1106 & 0.0491 & 0.5588 & 0.2983 & San Carlos & 0.2213 & 0.0357 & 0.6290 & 0.3685 \\
\hline San Pedro & 0.1035 & 0.0962 & 0.5900 & 0.3276 & Yapacaní & 0.1650 & 0.0767 & 0.5969 & 0.3482 \\
\hline Toro Toro & 0.0547 & 0.0494 & 0.7276 & 0.3452 & San Juan & 0.2071 & 0.0206 & 0.6838 & 0.3791 \\
\hline Cotagaita & 0.1469 & 0.1221 & 0.8180 & 0.4512 & San José & 0.2632 & 0.0346 & 0.6536 & 0.3959 \\
\hline Vitichi & 0.1082 & 0.0446 & 0.6695 & 0.3414 & Pailón & 0.2673 & 0.0214 & 0.3673 & 0.2731 \\
\hline Sacaca & 0.1237 & 0.0662 & 0.5503 & 0.3073 & Roboré & 0.2370 & 0.0509 & 0.6894 & 0.4064 \\
\hline Caripuyo & 0.1899 & 0.0358 & 0.5434 & 0.3197 & Portachuelo & 0.3038 & 0.0387 & 0.7606 & 0.4591 \\
\hline Tupiza & 0.2758 & 0.1361 & 0.7090 & 0.4656 & Santa Rosa del & & & & \\
\hline Atocha & 0.2569 & 0.0271 & 0.8334 & 0.4649 & Sara & & & & \\
\hline Colcha "K" & 0.1390 & 0.0428 & 0.6191 & 0.3327 & Colpa Belgica & 0.2305 & 0.0106 & 0.7074 & 0.3947 \\
\hline San Pedro de & 0.1886 & & 0.4904 & & Lagunillas & 0.1619 & 0.0197 & 0.6653 & 0.3521 \\
\hline Quemes & 0.1080 & 0.0035 & U & & Charagua & 0.3108 & 0.0636 & 0.7008 & 0.4473 \\
\hline San Pablo de & & & & & Cabezas & 0.2559 & 0.0305 & 0.5744 & 0.3581 \\
\hline Lipez & & & & & Cuevo & 0.2181 & 0.0127 & 0.6674 & 0.3737 \\
\hline Mojinete & 0.1480 & 0.0062 & 0.6632 & 0.3399 & Gutierrez & 0.1754 & 0.0387 & 0.6905 & 0.3761 \\
\hline San Antonio & & & & & Camiri & 0.4376 & 0.0620 & 0.7418 & 0.5169 \\
\hline de Esmoruco & $1 / 0$ & U. & U & & Boyuibe & 0.2167 & 0.0112 & 0.6065 & 0.3472 \\
\hline
\end{tabular}




\begin{tabular}{|c|c|c|c|c|c|c|c|c|c|}
\hline Municipality & $\begin{array}{c}\text { WBI } \\
\text { Material }\end{array}$ & $\begin{array}{c}\text { WBI } \\
\text { Social }\end{array}$ & $\begin{array}{c}\text { WBI } \\
\text { Human }\end{array}$ & $\begin{array}{c}\text { WBI } \\
\text { Total }\end{array}$ & Municipality & $\begin{array}{c}\text { WBI } \\
\text { Material }\end{array}$ & $\begin{array}{c}\text { WBI } \\
\text { Social }\end{array}$ & $\begin{array}{c}\text { WBI } \\
\text { Human }\end{array}$ & $\begin{array}{c}\text { WBI } \\
\text { Total }\end{array}$ \\
\hline Valle Grande & 0.2772 & 0.0865 & 0.6995 & 0.4420 & San Ramón & 0.1973 & 0.0142 & 0.4606 & 0.2796 \\
\hline El Trigal & 0.2497 & 0.0154 & 0.5394 & 0.3348 & Puerto Siles & 0.2757 & 0.0041 & 0.6084 & 0.3698 \\
\hline Moro Moro & 0.1667 & 0.0180 & 0.5746 & 0.3157 & Magdalena & 0.1474 & 0.0353 & 0.5985 & 0.3246 \\
\hline Postrer Valle & 0.0926 & 0.0129 & 0.4764 & 0.2417 & Baures & 0.1264 & 0.0126 & 0.5207 & 0.2742 \\
\hline Pucara & 0.0958 & 0.0165 & 0.5266 & 0.2654 & Huacaraje & 0.2325 & 0.0114 & 0.6462 & 0.3704 \\
\hline Samaipata & 0.1909 & 0.0352 & 0.5466 & 0.3213 & Cobija & 0.4328 & 0.0465 & 0.9039 & 0.5760 \\
\hline Pampa & (2002 & 00101 & 05205 & ( 2148 & Porvenir & 0.2408 & 0.0201 & 0.8326 & 0.4550 \\
\hline Grande & 0.2093 & 0.0191 & $0.0<80$ & 0.3148 & Bolpebra & 0.3567 & 0.0134 & 0.7457 & 0.4648 \\
\hline Mairana & 0.2094 & 0.0257 & 0.6992 & 0.3886 & Bella Flor & 0.3167 & 0.0155 & 0.7808 & 0.4634 \\
\hline Quirusillas & 0.1722 & 0.0072 & 0.4616 & 0.2666 & Puerto Rico & 0.4001 & 0.0267 & 0.7766 & 0.5012 \\
\hline Montero & 0.2878 & 0.0969 & 0.7881 & 0.4876 & San Pablo & 08216 & 0,0094 & 0.7373 & 0.6547 \\
\hline Gral. & 02145 & 0,0283 & 0.6784 & 03832 & (San Pedro) & 0.8210 & 0.0094 & $0.13 / 3$ & $0.034 /$ \\
\hline Saavedra & 0.2145 & & $0.0 / 84$ & 0.3832 & Filadelfia & 0.2672 & 0.0276 & 0.7279 & 0.4256 \\
\hline Mineros & 0.2815 & 0.0278 & 0.7067 & 0.4228 & Puerto & & & & \\
\hline $\begin{array}{l}\text { Fernandez } \\
\text { Alonso }\end{array}$ & 0.1683 & 0.0208 & 0.7895 & 0.4069 & $\begin{array}{l}\text { Gonzalo } \\
\text { Moreno }\end{array}$ & 0.2483 & 0.0198 & 0.7485 & 0.4230 \\
\hline San Pedro & 0.2463 & 0.0309 & 0.7273 & 0.4179 & San Lorenzo & 0.4672 & 0.0243 & 0.8054 & 0.5404 \\
\hline Concepción & 0.1393 & 0.0339 & 0.5287 & 0.2916 & Sena & 0.4134 & 0.0143 & 0.6438 & 0.4465 \\
\hline San Javier & 0.1288 & 0.0247 & 0.5660 & 0.2990 & Nacebe (Santa & & & & \\
\hline San Ramon & 0.1137 & 0.0200 & 0.7060 & 0.3489 & Rosa de & 0.3175 & 0.0055 & 0.4149 & 0.3074 \\
\hline San Julián & 0.3303 & 0.0923 & 0.6159 & 0.4319 & Abuna) & & & & \\
\hline $\begin{array}{l}\text { San Antonio } \\
\text { de Lomerio }\end{array}$ & 0.2008 & 0.0221 & 0.4458 & 0.2781 & $\begin{array}{l}\text { Ingavi } \\
\text { Nuevo Manoa }\end{array}$ & 0.0453 & 0.0044 & 0.6731 & 0.3001 \\
\hline $\begin{array}{l}\text { Cuatro } \\
\text { Canadas }\end{array}$ & 0.2527 & 0.0298 & 0.5096 & 0.3296 & $\begin{array}{l}\text { (Nueva } \\
\text { Esperanza }\end{array}$ & 0.2720 & 0.0044 & 0.6524 & 0.3867 \\
\hline San Matías & 0.1409 & 0.0379 & 0.5550 & 0.3048 & Villa Nueva & 0.1987 & 0.0085 & 0.6159 & 0.3425 \\
\hline Comarapa & 0.2129 & 0.0444 & 0.6840 & 0.3914 & Eureka & & & & \\
\hline Saipina & 0.1946 & 0.0128 & 0.5548 & 0.3170 & (Santos & 0.0723 & 0.0035 & 0.6502 & 0.3016 \\
\hline Puerto Suarez & 0.2990 & 0.0253 & 0.7202 & 0.4347 & Mercado) & & & & \\
\hline $\begin{array}{l}\text { Puerto } \\
\text { Quijarro }\end{array}$ & 0.1935 & 0.0174 & 0.6309 & 0.3501 & & & & & \\
\hline $\begin{array}{l}\text { Carmen } \\
\text { Rivero Torres }\end{array}$ & 0.1739 & 0.0158 & 0.6167 & 0.3354 & & & & & \\
\hline $\begin{array}{l}\text { Ascención de } \\
\text { Guarayos }\end{array}$ & 0.0955 & 0.0220 & 0.6309 & 0.3109 & & & & & \\
\hline Urubicha & 0.0537 & 0.0143 & 0.7151 & 0.3252 & & & & & \\
\hline El Puente & 0.1501 & 0.0287 & 0.5655 & 0.3094 & & & & & \\
\hline Trinidad & 0.3204 & 0.1173 & 0.6797 & 0.4645 & & & & & \\
\hline San Javier & 0.3095 & 0.0184 & 0.6331 & 0.4001 & & & & & \\
\hline Riberalta & 0.2478 & 0.1274 & 0.6629 & 0.4311 & & & & & \\
\hline Guayaramerín & 0.2486 & 0.0754 & 0.6095 & 0.3880 & & & & & \\
\hline Reyes & 0.1785 & 0.0431 & 0.6031 & 0.3428 & & & & & \\
\hline San Borja & 0.1741 & 0.0968 & 0.6721 & 0.3916 & & & & & \\
\hline Santa Rosa & 0.2347 & 0.0213 & 0.6486 & 0.3764 & & & & & \\
\hline Rurrenabaque & 0.2452 & 0.0351 & 0.6210 & 0.3750 & & & & & \\
\hline Santa Ana & 0.3074 & 0.0369 & 0.5194 & 0.3595 & & & & & \\
\hline Exaltación & 0.1909 & 0.0194 & 0.2939 & 0.2097 & & & & & \\
\hline San Ignacio & 0.1924 & 0.0937 & 0.6175 & 0.3752 & & & & & \\
\hline Loreto & 0.2981 & 0.0219 & 0.6744 & 0.4140 & & & & & \\
\hline San Andrés & 0.2650 & 0.0400 & 0.5677 & 0.3631 & & & & & \\
\hline San Joaquín & 0.1520 & 0.0180 & 0.5701 & 0.3076 & & & & & \\
\hline
\end{tabular}


WBI values estimated by DP2 for period 2000-2011

\begin{tabular}{|c|c|c|c|c|c|}
\hline Municipality & $\begin{array}{c}\text { WBI 2000- } \\
2005\end{array}$ & $\begin{array}{c}\text { WBI 2006- } \\
2011\end{array}$ & Municipality & $\begin{array}{c}\text { WBI 2000- } \\
2005\end{array}$ & $\begin{array}{c}\text { WBI 2006- } \\
2011\end{array}$ \\
\hline Sucre & 0.675 & 0.464 & Sorata & 0.470 & 0.385 \\
\hline Yotala & 0.595 & 0.430 & Guanay & 0.698 & 0.483 \\
\hline Poroma & 0.528 & 0.455 & Tacacoma & 0.516 & 0.446 \\
\hline Azurduy & 0.571 & 0.452 & Quiabaya & 0.617 & 0.414 \\
\hline Tarvita & 0.644 & 0.418 & Combaya & 0.558 & 0.388 \\
\hline Zudañez & 0.509 & 0.412 & Tipuani & 0.578 & 0.493 \\
\hline Presto & 0.452 & 0.422 & Mapiri & 0.644 & 0.526 \\
\hline Mojocoya & 0.525 & 0.400 & Teoponte & 0.607 & 0.497 \\
\hline Icla & 0.580 & 0.465 & Apolo & 0.527 & 0.479 \\
\hline Padilla & 0.530 & 0.384 & Pelechuco & 0.758 & 0.407 \\
\hline Tomina & 0.515 & 0.425 & Viacha & 0.553 & 0.442 \\
\hline Sopachuy & 0.514 & 0.404 & Guaqui & 0.465 & 0.355 \\
\hline Villa Alcalá & 0.418 & 0.321 & Tiahuanacu & 0.587 & 0.384 \\
\hline El Villar & 0.490 & 0.364 & Desaguadero & 0.645 & 0.508 \\
\hline Monteagudo & 0.515 & 0.389 & San Andres de & 4423 & 0352 \\
\hline Huacareta & 0.547 & 0.417 & Machaca & $0.4 \angle J$ & 0.032 \\
\hline Tarabuco & 0.603 & 0.450 & Jesus de Machaca & 0.455 & 0.380 \\
\hline Yamparaez & 0.585 & 0.381 & Taraco & 0.406 & 0.307 \\
\hline Camargo & 0.560 & 0.402 & Luribay & 0.681 & 0.429 \\
\hline San Lucas & 0.585 & 0.437 & Sapahaqui & 0.511 & 0.321 \\
\hline Incahuasi & 0.503 & 0.419 & Yaco & 0.525 & 0.421 \\
\hline Villa Serrano & 0.599 & 0.407 & Malla & 0.377 & 0.268 \\
\hline Camataqui (Villa & 0523 & 0331 & Cairoma & 0.548 & 0.407 \\
\hline Abecia) & 0.523 & 0.331 & Inquisivi & 0.487 & 0.330 \\
\hline Culpina & 0.587 & 0.489 & Quime & 0.490 & 0.413 \\
\hline Las Carreras & 0.493 & 0.334 & Cajuata & 0.621 & 0.573 \\
\hline Villa Vaca Guzman & 0.534 & 0.324 & Colquiri & 0.573 & 0.456 \\
\hline Huacaya & 0.484 & 0.444 & Ichoca & 0.498 & 0.347 \\
\hline Macharetí & 0.467 & 0.339 & Licoma Pampa & 0.477 & 0.331 \\
\hline La Paz & 0.729 & 0.449 & Chulumani & 0.602 & 0.491 \\
\hline Palca & 0.515 & 0.421 & Irupana & 0.579 & 0.461 \\
\hline Мecapaca & 0.538 & 0.405 & Yanacachi & 0.510 & 0.350 \\
\hline Achocalla & 0.490 & 0.381 & Palos Blancos & 0.644 & 0.517 \\
\hline El Alto & 0.619 & 0.408 & La Asunta & 0.602 & 0.512 \\
\hline Achacachi & 0.548 & 0.371 & Pucarani & 0.490 & 0.371 \\
\hline Ancoraimes & 0.572 & 0.388 & Laja & 0.521 & 0.395 \\
\hline Coro Coro & 0.457 & 0.318 & Batallas & 0.518 & 0.361 \\
\hline Caquiaviri & 0.524 & 0.339 & Puerto Pérez & 0.530 & 0.302 \\
\hline Calacoto & 0.542 & 0.330 & Sica Sica & 0.501 & 0.292 \\
\hline Comanche & 0.566 & 0.433 & Umala & 0.451 & 0.324 \\
\hline Charaña & 0.641 & 0.383 & Ауо Ауо & 0.516 & 0.398 \\
\hline Waldo Ballivian & 0.669 & 0.428 & Calamarca & 0.539 & 0.359 \\
\hline Nazacara de Pacajes & 0.798 & 0.596 & Patacamaya & 0.575 & 0.394 \\
\hline Santiago de Callapa & 0.450 & 0.319 & Colquencha & 0.483 & 0.348 \\
\hline Puerto Acosta & 0.547 & 0.416 & Collana & 0.421 & 0.296 \\
\hline Moco Moco & 0.608 & 0.463 & Coroico & 0.583 & 0.465 \\
\hline Carabuco & 0.483 & 0.361 & Coripata & 0.620 & 0.466 \\
\hline Chuma & 0.480 & 0.286 & Ixiamas & 0.528 & 0.456 \\
\hline Ayata & 0.572 & 0.396 & San Buena Ventura & 0.603 & 0.502 \\
\hline Aucapata & 0.613 & 0.564 & Gral. Juan José Perez & 0.516 & 0.423 \\
\hline
\end{tabular}




\begin{tabular}{|c|c|c|c|c|c|}
\hline Municipality & $\begin{array}{c}\text { WBI 2000- } \\
2005 \\
\end{array}$ & $\begin{array}{c}\text { WBI 2006- } \\
2011 \\
\end{array}$ & Municipality & $\begin{array}{c}\text { WBI 2000- } \\
2005 \\
\end{array}$ & $\begin{array}{c}\text { WBI 2006- } \\
2011 \\
\end{array}$ \\
\hline Curva & 0.432 & 0.316 & San Benito & 0.497 & 0.371 \\
\hline Copacabana & 0.499 & 0.413 & Tacachi & 0.382 & 0.190 \\
\hline San Pedro de Tiquina & 0.460 & 0.301 & Cuchumuela & 0.485 & 0.357 \\
\hline Tito Yupanqui & 0.458 & 0.221 & Bolivar & 0.499 & 0.404 \\
\hline San Pedro de & \multirow{2}{*}{0.519} & \multirow{2}{*}{0.310} & Tiraque & 0.611 & 0.482 \\
\hline Curahuara & & & Oruro & 0.664 & 0.538 \\
\hline Papel Pampa & 0.550 & 0.413 & Caracollo & 0.593 & 0.459 \\
\hline Chacarilla & 0.409 & 0.399 & El Choro & 0.399 & 0.351 \\
\hline Santiago de Machaca & 0.453 & 0.368 & Paria & 0.517 & 0.387 \\
\hline Catacora & 0.359 & 0.200 & Challapata & 0.534 & 0.449 \\
\hline Caranavi & 0.526 & 0.459 & Santuario de Quillacas & 0.377 & 0.354 \\
\hline Cochabamba & 0.669 & 0.484 & Corque & 0.544 & 0.428 \\
\hline Aiquile & 0.493 & 0.366 & Choque Cota & 0.451 & 0.377 \\
\hline Pasorapa & 0.405 & 0.319 & Curahuara de & \multirow{2}{*}{0.565} & \multirow{2}{*}{0.454} \\
\hline Omereque & 0.531 & 0.379 & Carangas & & \\
\hline Ayopaya & 0.558 & 0.458 & Turco & 0.747 & 0.441 \\
\hline Morochata & 0.459 & 0.342 & Huachacalla & 0.431 & 0.161 \\
\hline Tarata & 0.637 & 0.498 & Escara & 0.327 & 0.255 \\
\hline Anzaldo & 0.535 & 0.425 & Cruz de & \multirow{2}{*}{0.000} & \multirow{2}{*}{0.000} \\
\hline Arbieto & 0.489 & 0.447 & Machacamarca & & \\
\hline Sacabamba & 0.592 & 0.431 & Yunguyo de Litoral & 0.159 & 0.132 \\
\hline Arani & 0.546 & 0.462 & Esmeralda & 0.218 & 0.175 \\
\hline Vacas & 0.511 & 0.267 & Poopó & 0.446 & 0.432 \\
\hline Arque & 0.505 & 0.336 & Pazña & 0.553 & 0.543 \\
\hline Tacopaya & 0.519 & 0.352 & Antequera & 0.455 & 0.437 \\
\hline Capinota & 0.595 & 0.485 & Huanuni & 0.662 & 0.593 \\
\hline Santivañez & 0.509 & 0.340 & Machacamarca & 0.545 & 0.459 \\
\hline Sicaya & 0.605 & 0.520 & Salinas G. de & \multirow{2}{*}{0.503} & \multirow{2}{*}{0.471} \\
\hline Cliza & 0.564 & 0.434 & Mendoza & & \\
\hline Toko & 0.454 & 0.436 & Pampa Aullagas & 0.451 & 0.407 \\
\hline Tolata & 0.513 & 0.340 & Sabaya & 0.418 & 0.264 \\
\hline Quillacollo & 0.547 & 0.385 & Coipasa & 0.566 & 0.456 \\
\hline Sipe Sipe & 0.532 & 0.401 & Chipaya & 0.613 & 0.476 \\
\hline Tiquipaya & 0.538 & 0.340 & Toledo & 0.514 & 0.438 \\
\hline Vinto & 0.520 & 0.425 & Eucaliptus & 0.616 & 0.436 \\
\hline Colcapirhua & 0.401 & 0.295 & Andamarca & 0.610 & 0.427 \\
\hline Sacaba & 0.468 & 0.340 & Belén de Andamarca & 0.519 & 0.448 \\
\hline Colomi & 0.634 & 0.473 & Totora & 0.588 & 0.475 \\
\hline Villa Tunari & 0.523 & 0.464 & Santiago de Huari & 0.429 & 0.355 \\
\hline Tapacari & 0.533 & 0.414 & La Rivera & 0.474 & 0.307 \\
\hline Totora & 0.533 & 0.385 & Todos Santos & 0.478 & 0.313 \\
\hline Pojo & 0.671 & 0.303 & Carangas & 0.446 & 0.340 \\
\hline Pocona & 0.540 & 0.384 & Huayllamarca & 0.643 & 0.429 \\
\hline Chimoré & 0.542 & 0.377 & Potosí & 0.667 & 0.550 \\
\hline Puerto Villarroel & 0.586 & 0.436 & Tinguipaya & 0.575 & 0.395 \\
\hline Entre Rios (Bulo Bulo) & 0.507 & 0.397 & Yocalla & 0.559 & 0.434 \\
\hline Mizque & 0.520 & 0.354 & Urmiri & 0.552 & 0.341 \\
\hline Vila Vila & 0.438 & 0.413 & Uncia & 0.586 & 0.479 \\
\hline Alalay & 0.422 & 0.266 & Chayanta & 0.559 & 0.508 \\
\hline Punata & 0.616 & 0.498 & Llallagua & 0.584 & 0.508 \\
\hline Villa Rivero & 0.528 & 0.421 & Betanzos & 0.557 & 0.400 \\
\hline
\end{tabular}




\begin{tabular}{|c|c|c|c|c|c|}
\hline Municipality & $\begin{array}{c}\text { WBI 2000- } \\
2005\end{array}$ & $\begin{array}{c}\text { WBI 2006- } \\
2011 \\
\end{array}$ & Municipality & $\begin{array}{c}\text { WBI 2000- } \\
2005 \\
\end{array}$ & $\begin{array}{c}\text { WBI 2006- } \\
2011 \\
\end{array}$ \\
\hline Chaqui & 0.500 & 0.425 & San Miguel & 0.492 & 0.344 \\
\hline Tacobamba & 0.417 & 0.368 & San Rafael & 0.414 & 0.330 \\
\hline Colquechaca & 0.532 & 0.411 & Buena Vista & 0.537 & 0.379 \\
\hline Ravelo & 0.497 & 0.378 & San Carlos & 0.591 & 0.420 \\
\hline Pocoata & 0.614 & 0.498 & Yapacaní & 0.517 & 0.418 \\
\hline Ocurí & 0.461 & 0.437 & San Juan & 0.524 & 0.418 \\
\hline San Pedro & 0.549 & 0.429 & San José & 0.555 & 0.464 \\
\hline Toro Toro & 0.591 & 0.509 & Pailón & 0.295 & 0.261 \\
\hline Cotagaita & 0.690 & 0.552 & Roboré & 0.587 & 0.514 \\
\hline Vitichi & 0.587 & 0.479 & Portachuelo & 0.655 & 0.507 \\
\hline Sacaca & 0.497 & 0.399 & Santa Rosa del Sara & 0.524 & 0.355 \\
\hline Caripuyo & 0.560 & 0.443 & Colpa Belgica & 0.477 & 0.445 \\
\hline Tupiza & 0.599 & 0.527 & Lagunillas & 0.573 & 0.450 \\
\hline Atocha & 0.743 & 0.597 & Charagua & 0.665 & 0.449 \\
\hline Colcha "K" & 0.581 & 0.392 & Cabezas & 0.447 & 0.351 \\
\hline San Pedro de Quemes & 0.502 & 0.227 & Cuevo & 0.623 & 0.440 \\
\hline San Pablo de Lipez & 0.739 & 0.470 & Gutierrez & 0.647 & 0.470 \\
\hline Mojinete & 0.657 & 0.410 & Camiri & 0.753 & 0.599 \\
\hline San Antonio de & & & Boyuibe & 0.579 & 0.418 \\
\hline Esmoruco & 0.514 & 0.395 & Valle Grande & 0.659 & 0.494 \\
\hline Puna & 0.499 & 0.440 & El Trigal & 0.541 & 0.419 \\
\hline Caiza "D" & 0.576 & 0.444 & Moro Moro & 0.557 & 0.407 \\
\hline Uyuni & 0.634 & 0.537 & Postrer Valle & 0.413 & 0.310 \\
\hline Tomave & 0.540 & 0.371 & Pucara & 0.464 & 0.329 \\
\hline Porco & 0.589 & 0.620 & Samaipata & 0.501 & 0.403 \\
\hline Arampampa & 0.863 & 0.597 & Pampa Grande & 0.492 & 0.378 \\
\hline Acasio & 0.862 & 0.625 & Mairana & 0.621 & 0.431 \\
\hline Llica & 0.678 & 0.483 & Quirusillas & 0.441 & 0.282 \\
\hline Tahua & 0.394 & 0.328 & Montero & 0.673 & 0.518 \\
\hline Villazón & 0.678 & 0.491 & Gral. Saavedra & 0.587 & 0.437 \\
\hline San Agustín & 0.664 & 0.455 & Mineros & 0.695 & 0.469 \\
\hline Tarija & 0.594 & 0.458 & Fernandez Alonso & 0.576 & 0.448 \\
\hline Padcaya & 0.548 & 0.454 & San Pedro & 0.584 & 0.434 \\
\hline Bermejo & 0.605 & 0.480 & Concepción & 0.476 & 0.360 \\
\hline Yacuiba & 0.482 & 0.386 & San Javier & 0.528 & 0.369 \\
\hline Carapari & 0.738 & 1.000 & San Ramon & 0.569 & 0.422 \\
\hline Villamontes & 0.730 & 0.624 & San Julián & 0.611 & 0.473 \\
\hline Uriondo & 0.555 & 0.515 & San Antonio de & & \\
\hline Yunchara & 0.621 & 0.618 & Lomerio & 0.510 & 0.277 \\
\hline San Lorenzo & 0.541 & 0.525 & Cuatro Canadas & 0.381 & 0.302 \\
\hline El Puente & 0.603 & 0.528 & San Matías & 0.479 & 0.391 \\
\hline Entre Ríos & 0.641 & 0.570 & Comarapa & 0.629 & 0.488 \\
\hline Santa Cruz de la & 0.580 & 0.409 & Saipina & 0.513 & 0.386 \\
\hline Sierra & 0.580 & 0.409 & Puerto Suarez & 0.665 & 0.499 \\
\hline Cotoca & 0.564 & 0.412 & Puerto Quijarro & 0.535 & 0.381 \\
\hline Ayacucho & 0.564 & 0.376 & Carmen Rivero Torres & 0.454 & 0.417 \\
\hline La Guardia & 0.569 & 0.437 & Ascención de & & \\
\hline El Torno & 0.565 & 0.407 & Guarayos & 0.550 & 0.426 \\
\hline Warnes & 0.587 & 0.548 & Urubicha & 0.567 & 0.459 \\
\hline Okinawa 1 & 0.512 & 0.430 & El Puente & 0.470 & 0.391 \\
\hline San Ignacio & 0.518 & 0.427 & Trinidad & 0.629 & 0.528 \\
\hline
\end{tabular}




\begin{tabular}{|c|c|c|c|c|c|}
\hline Municipality & $\begin{array}{c}\text { WBI 2000- } \\
2005\end{array}$ & $\begin{array}{c}\text { WBI 2006- } \\
2011\end{array}$ & Municipality & $\begin{array}{c}\text { WBI 2000- } \\
2005\end{array}$ & $\begin{array}{c}\text { WBI 2006- } \\
2011\end{array}$ \\
\hline San Javier & 0.551 & 0.503 & Porvenir & 0.614 & 0.642 \\
\hline Riberalta & 0.639 & 0.505 & Bolpebra & 0.675 & 0.587 \\
\hline Guayaramerín & 0.518 & 0.494 & Bella Flor & 0.585 & 0.652 \\
\hline Reyes & 0.524 & 0.389 & Puerto Rico & 0.686 & 0.749 \\
\hline San Borja & 0.518 & 0.493 & San Pablo (San Pedro) & 1.000 & 0.805 \\
\hline Santa Rosa & 0.532 & 0.439 & Filadelfia & 0.549 & 0.601 \\
\hline Rurrenabaque & 0.596 & 0.442 & Puerto Gonzalo & 0617 & 0560 \\
\hline Santa Ana & 0.543 & 0.422 & Moreno & 0.017 & 0.569 \\
\hline Exaltación & 0.245 & 0.178 & San Lorenzo & 0.785 & 0.744 \\
\hline San Ignacio & 0.518 & 0.476 & Sena & 0.600 & 0.683 \\
\hline Loreto & 0.603 & 0.502 & Nacebe (Santa Rosa de & 20282 & 0540 \\
\hline San Andrés & 0.518 & 0.439 & Abuna) & 0.282 & 0.540 \\
\hline San Joaquín & 0.533 & 0.376 & Ingavi & 0.326 & 0.523 \\
\hline San Ramón & 0.426 & 0.338 & Nuevo Manoa (Nueva & 0500 & 0657 \\
\hline Puerto Siles & 0.523 & 0.442 & Esperanza & 0.500 & $0.65 \%$ \\
\hline Magdalena & 0.525 & 0.391 & Villa Nueva & 0.438 & 0.677 \\
\hline Baures & 0.437 & 0.367 & Eureka (Santos & 0365 & 0485 \\
\hline Huacaraje & 0.534 & 0.473 & Mercado) & 0.365 & 0.485 \\
\hline
\end{tabular}

WBI values estimated by DP2 for years 2002, 2003, 2006 \& 2007

\begin{tabular}{|c|c|c|c|c|c|c|c|c|c|}
\hline Municipality & $\begin{array}{l}\text { WBI } \\
2002\end{array}$ & $\begin{array}{l}\text { WBI } \\
2003\end{array}$ & $\begin{array}{l}\text { WBI } \\
2006\end{array}$ & $\begin{array}{l}\text { WBI } \\
2007\end{array}$ & $\begin{array}{l}\text { Villa Vaca } \\
\text { Guzman }\end{array}$ & 0.475 & 0.414 & 0.280 & 0.305 \\
\hline Sucre & 0.596 & 0.633 & 0.491 & 0.356 & \multirow{2}{*}{ Municipality } & WBI & WBI & WBI & WBI \\
\hline Yotala & 0.519 & 0.486 & 0.486 & 0.372 & & 2002 & 2003 & 2006 & 2007 \\
\hline Poroma & 0.339 & 0.407 & 0.378 & 0.298 & Huacaya & 0.311 & 0.383 & 0.404 & 0.333 \\
\hline Azurduy & 0.371 & 0.325 & 0.405 & 0.267 & Macharetí & 0.355 & 0.446 & 0.309 & 0.263 \\
\hline Tarvita & 0.387 & 0.528 & 0.371 & 0.297 & $\mathrm{La} \mathrm{Paz}$ & 0.701 & 0.748 & 0.566 & 0.435 \\
\hline Zudañez & 0.479 & 0.492 & 0.465 & 0.356 & Palca & 0.344 & 0.418 & 0.439 & 0.328 \\
\hline Presto & 0.248 & 0.309 & 0.275 & 0.271 & Mecapaca & 0.481 & 0.500 & 0.496 & 0.429 \\
\hline Mojocoya & 0.401 & 0.350 & 0.353 & 0.346 & Achocalla & 0.465 & 0.486 & 0.483 & 0.445 \\
\hline Icla & 0.379 & 0.439 & 0.403 & 0.274 & El Alto & 0.584 & 0.692 & 0.524 & 0.444 \\
\hline Padilla & 0.422 & 0.459 & 0.367 & 0.324 & Achacachi & 0.447 & 0.465 & 0.382 & 0.359 \\
\hline Tomina & 0.381 & 0.393 & 0.361 & 0.293 & Ancoraimes & 0.360 & 0.429 & 0.358 & 0.321 \\
\hline Sopachuy & 0.435 & 0.417 & 0.407 & 0.363 & Coro Coro & 0.328 & 0.366 & 0.310 & 0.296 \\
\hline Villa Alcalá & 0.355 & 0.430 & 0.299 & 0.332 & Caquiaviri & 0.353 & 0.391 & 0.277 & 0.274 \\
\hline El Villar & 0.402 & 0.424 & 0.397 & 0.357 & Calacoto & 0.338 & 0.382 & 0.239 & 0.262 \\
\hline Monteagudo & 0.458 & 0.530 & 0.436 & 0.344 & Comanche & 0.470 & 0.446 & 0.384 & 0.373 \\
\hline Huacareta & 0.373 & 0.406 & 0.354 & 0.312 & Charaña & 0.388 & 0.478 & 0.420 & 0.359 \\
\hline Tarabuco & 0.409 & 0.494 & 0.402 & 0.339 & Waldo & & & & \\
\hline Yamparaez & 0.463 & 0.507 & 0.420 & 0.429 & Ballivian & 0.543 & 0.535 & 0.347 & 0.457 \\
\hline Camargo & 0.476 & 0.472 & 0.458 & 0.350 & Nazacara de & & & & \\
\hline San Lucas & 0.481 & 0.563 & 0.408 & 0.368 & Pacajes & 0.402 & 0.335 & 0.031 & 0.082 \\
\hline Incahuasi & 0.379 & 0.416 & 0.408 & 0.309 & Santiago de & & & & \\
\hline Villa Serrano & 0.430 & 0.519 & 0.438 & 0.292 & Callapa & 0.324 & 0.336 & 0.250 & 0.252 \\
\hline Camataqui & & & & & Puerto Acosta & 0.360 & 0.372 & 0.318 & 0.273 \\
\hline (Villa Abecia) & 0.500 & 0.656 & 0.444 & 0.345 & Moco Moco & 0.441 & 0.449 & 0.410 & 0.345 \\
\hline Culpina & 0.374 & 0.423 & 0.381 & 0.297 & Carabuco & 0.350 & 0.351 & 0.352 & 0.317 \\
\hline Las Carreras & 0.371 & 0.389 & 0.342 & 0.273 & Chuma & 0.247 & 0.364 & 0.251 & 0.212 \\
\hline
\end{tabular}




\begin{tabular}{|c|c|c|c|c|c|c|c|c|c|}
\hline Ayata & 0.293 & 0.306 & 0.257 & 0.224 & San Buena & \multirow{2}{*}{0.479} & \multirow{2}{*}{0.564} & \multirow{2}{*}{0.455} & \multirow{2}{*}{0.331} \\
\hline Aucapata & 0.436 & 0.414 & 0.322 & 0.166 & Ventura & & & & \\
\hline Sorata & 0.369 & 0.383 & 0.326 & 0.321 & Gral. Juan José & \multirow{2}{*}{0.431} & \multirow{2}{*}{0.499} & \multirow{2}{*}{0.367} & \multirow{2}{*}{0.351} \\
\hline Guanay & 0.500 & 0.598 & 0.387 & 0.351 & Perez & & & & \\
\hline \multirow{2}{*}{ Municipality } & WBI & WBI & WBI & WBI & \multirow{2}{*}{ Municipality } & WBI & WBI & WBI & WBI \\
\hline & 2002 & 2003 & 2006 & 2007 & & 2002 & 2003 & 2006 & 2007 \\
\hline Tacacoma & 0.368 & 0.397 & 0.326 & 0.356 & Curva & 0.384 & 0.513 & 0.332 & 0.272 \\
\hline Quiabaya & 0.404 & 0.414 & 0.382 & 0.224 & Copacabana & 0.457 & 0.505 & 0.426 & 0.403 \\
\hline Combaya & 0.473 & 0.436 & 0.376 & 0.426 & San Pedro de & \multirow{2}{*}{0.458} & \multirow{2}{*}{0.551} & \multirow{2}{*}{0.353} & \multirow{2}{*}{0.292} \\
\hline Tipuani & 0.548 & 0.613 & 0.569 & 0.498 & Tiquina & & & & \\
\hline Mapiri & 0.459 & 0.480 & 0.455 & 0.391 & Tito Yupanqui & 0.308 & 0.226 & 0.252 & 0.257 \\
\hline Teoponte & 0.426 & 0.416 & 0.387 & 0.324 & San Pedro de & \multirow{2}{*}{0.377} & \multirow{2}{*}{0.501} & \multirow{2}{*}{0.294} & \multirow{2}{*}{0.254} \\
\hline Apolo & 0.360 & 0.412 & 0.365 & 0.340 & Curahuara & & & & \\
\hline Pelechuco & 1.000 & 0.882 & 0.363 & 0.279 & Papel Pampa & 0.397 & 0.441 & 0.150 & 0.247 \\
\hline Viacha & 0.488 & 0.545 & 0.470 & 0.395 & Chacarilla & 0.324 & 0.400 & 0.215 & 0.161 \\
\hline Guaqui & 0.475 & 0.571 & 0.411 & 0.356 & Santiago de & 0507 & 0518 & 0450 & 0240 \\
\hline Tiahuanacu & 0.534 & 0.561 & 0.462 & 0.407 & Machaca & $0.30 \%$ & 0.310 & 0.450 & 0.340 \\
\hline Desaguadero & 0.429 & 0.447 & 0.392 & 0.386 & Catacora & 0.380 & 0.438 & 0.238 & 0.216 \\
\hline San Andres de & 0240 & 0201 & 0223 & 0221 & Caranavi & 0.417 & 0.472 & 0.440 & 0.369 \\
\hline Machaca & 0.240 & 0.221 & 0.233 & 0.231 & Cochabamba & 0.632 & 0.722 & 0.584 & 0.474 \\
\hline Jesus de & 0344 & 0332 & 0296 & 0273 & Aiquile & 0.538 & 0.494 & 0.483 & 0.308 \\
\hline Machaca & 0.344 & 0.333 & 0.296 & 0.273 & Pasorapa & 0.386 & 0.411 & 0.370 & 0.316 \\
\hline Taraco & 0.243 & 0.247 & 0.278 & 0.308 & Omereque & 0.331 & 0.344 & 0.265 & 0.293 \\
\hline Luribay & 0.454 & 0.486 & 0.438 & 0.420 & Ayopaya & 0.414 & 0.453 & 0.390 & 0.321 \\
\hline Sapahaqui & 0.336 & 0.449 & 0.358 & 0.258 & Morochata & 0.351 & 0.405 & 0.386 & 0.264 \\
\hline Yaco & 0.382 & 0.387 & 0.352 & 0.325 & Tarata & 0.597 & 0.633 & 0.498 & 0.421 \\
\hline Malla & 0.293 & 0.252 & 0.217 & 0.229 & Anzaldo & 0.439 & 0.498 & 0.408 & 0.297 \\
\hline Cairoma & 0.367 & 0.391 & 0.394 & 0.353 & Arbieto & 0.396 & 0.340 & 0.328 & 0.291 \\
\hline Inquisivi & 0.292 & 0.291 & 0.411 & 0.326 & Sacabamba & 0.505 & 0.481 & 0.343 & 0.330 \\
\hline Quime & 0.430 & 0.514 & 0.295 & 0.349 & Arani & 0.394 & 0.403 & 0.453 & 0.400 \\
\hline Cajuata & 0.390 & 0.484 & 0.368 & 0.352 & Vacas & 0.485 & 0.505 & 0.396 & 0.416 \\
\hline Colquiri & 0.340 & 0.408 & 0.325 & 0.364 & Arque & 0.273 & 0.300 & 0.372 & 0.300 \\
\hline Ichoca & 0.328 & 0.353 & 0.262 & 0.243 & Tacopaya & 0.393 & 0.589 & 0.334 & 0.224 \\
\hline Licoma Pampa & 0.357 & 0.319 & 0.331 & 0.227 & Capinota & 0.513 & 0.579 & 0.547 & 0.402 \\
\hline Chulumani & 0.494 & 0.505 & 0.491 & 0.408 & Santivañez & 0.496 & 0.504 & 0.475 & 0.382 \\
\hline Irupana & 0.375 & 0.451 & 0.447 & 0.372 & Sicaya & 0.352 & 0.419 & 0.320 & 0.412 \\
\hline Yanacachi & 0.337 & 0.389 & 0.335 & 0.299 & Cliza & 0.606 & 0.604 & 0.464 & 0.410 \\
\hline Palos Blancos & 0.400 & 0.458 & 0.407 & 0.380 & Toko & 0.482 & 0.382 & 0.415 & 0.348 \\
\hline La Asunta & 0.290 & 0.324 & 0.389 & 0.341 & Tolata & 0.524 & 0.569 & 0.449 & 0.366 \\
\hline Pucarani & 0.442 & 0.452 & 0.425 & 0.375 & Quillacollo & 0.487 & 0.572 & 0.463 & 0.381 \\
\hline Laja & 0.454 & 0.511 & 0.416 & 0.345 & Sipe Sipe & 0.483 & 0.505 & 0.461 & 0.339 \\
\hline Batallas & 0.481 & 0.520 & 0.422 & 0.397 & Tiquipaya & 0.511 & 0.504 & 0.395 & 0.303 \\
\hline Puerto Pérez & 0.517 & 0.476 & 0.357 & 0.335 & Vinto & 0.565 & 0.605 & 0.536 & 0.412 \\
\hline Sica Sica & 0.382 & 0.359 & 0.279 & 0.263 & Colcapirhua & 0.450 & 0.441 & 0.367 & 0.313 \\
\hline Umala & 0.320 & 0.312 & 0.250 & 0.221 & Sacaba & 0.435 & 0.394 & 0.362 & 0.281 \\
\hline Ayo Ayo & 0.534 & 0.507 & 0.384 & 0.375 & Colomi & 0.553 & 0.639 & 0.512 & 0.404 \\
\hline Calamarca & 0.381 & 0.475 & 0.339 & 0.299 & Villa Tunari & 0.502 & 0.504 & 0.480 & 0.389 \\
\hline Patacamaya & 0.556 & 0.551 & 0.509 & 0.325 & Tapacari & 0.396 & 0.563 & 0.334 & 0.299 \\
\hline Colquencha & 0.298 & 0.404 & 0.275 & 0.234 & Totora & 0.405 & 0.404 & 0.428 & 0.364 \\
\hline Collana & 0.341 & 0.389 & 0.255 & 0.144 & Pojo & 0.570 & 0.556 & 0.305 & 0.260 \\
\hline Coroico & 0.501 & 0.575 & 0.508 & 0.430 & Pocona & 0.461 & 0.464 & 0.377 & 0.343 \\
\hline Coripata & 0.480 & 0.603 & 0.455 & 0.392 & Chimoré & 0.412 & 0.431 & 0.380 & 0.279 \\
\hline Ixiamas & 0.406 & 0.462 & 0.371 & 0.331 & & & & & \\
\hline
\end{tabular}




\begin{tabular}{|c|c|c|c|c|c|c|c|c|c|}
\hline $\begin{array}{l}\text { Puerto } \\
\text { Villarroel }\end{array}$ & 0.507 & 0.514 & 0.474 & 0.381 & $\begin{array}{l}\text { Santiago de } \\
\text { Huari }\end{array}$ & 0.317 & 0.430 & 0.319 & 0.300 \\
\hline Entre Rios & 0367 & 0350 & 0.44 & ק & La Rivera & 0.474 & 0.266 & 0.266 & 0.258 \\
\hline (Bulo Bulo) & $0.36 \%$ & 0.359 & 0.414 & 0.280 & Todos Santos & 0.599 & 0.675 & 0.485 & 0.416 \\
\hline Mizque & 0.431 & 0.415 & 0.371 & 0.313 & Carangas & 0.226 & 0.086 & 0.000 & 0.107 \\
\hline \multirow{2}{*}{ Municipality } & WBI & WBI & WBI & WBI & \multirow{2}{*}{ Municipality } & WBI & WBI & WBI & WBI \\
\hline & 2002 & 2003 & 2006 & 2007 & & 2002 & 2003 & 2006 & 2007 \\
\hline Vila Vila & 0.441 & 0.430 & 0.402 & 0.313 & Huayllamarca & 0.609 & 0.499 & 0.354 & 0.318 \\
\hline Alalay & 0.387 & 0.398 & 0.277 & 0.247 & Potosí & 0.668 & 0.745 & 0.542 & 0.409 \\
\hline Punata & 0.648 & 0.656 & 0.576 & 0.520 & Tinguipaya & 0.350 & 0.383 & 0.342 & 0.242 \\
\hline Villa Rivero & 0.639 & 0.640 & 0.584 & 0.427 & Yocalla & 0.445 & 0.510 & 0.310 & 0.302 \\
\hline San Benito & 0.483 & 0.545 & 0.525 & 0.409 & Urmiri & 0.405 & 0.394 & 0.244 & 0.216 \\
\hline Tacachi & 0.317 & 0.473 & 0.249 & 0.204 & Uncia & 0.536 & 0.517 & 0.526 & 0.364 \\
\hline Cuchumuela & 0.427 & 0.650 & 0.448 & 0.409 & Chayanta & 0.436 & 0.476 & 0.431 & 0.360 \\
\hline Bolivar & 0.374 & 0.469 & 0.314 & 0.266 & Llallagua & 0.573 & 0.597 & 0.575 & 0.452 \\
\hline Tiraque & 0.509 & 0.561 & 0.527 & 0.419 & Betanzos & 0.442 & 0.423 & 0.366 & 0.284 \\
\hline Oruro & 0.609 & 0.598 & 0.515 & 0.433 & Chaqui & 0.449 & 0.454 & 0.339 & 0.255 \\
\hline Caracollo & 0.463 & 0.342 & 0.429 & 0.262 & Tacobamba & 0.333 & 0.385 & 0.291 & 0.214 \\
\hline El Choro & 0.132 & 0.032 & 0.041 & 0.067 & Colquechaca & 0.242 & 0.361 & 0.304 & 0.255 \\
\hline Paria & 0.402 & 0.424 & 0.459 & 0.308 & Ravelo & 0.315 & 0.379 & 0.282 & 0.262 \\
\hline Challapata & 0.500 & 0.442 & 0.474 & 0.389 & Pocoata & 0.442 & 0.400 & 0.377 & 0.297 \\
\hline Santuario de & \multirow{2}{*}{0.290} & \multirow{2}{*}{0.240} & \multirow{2}{*}{0.266} & \multirow{2}{*}{0.283} & Ocurí & 0.350 & 0.386 & 0.351 & 0.296 \\
\hline Quillacas & & & & & San Pedro & 0.288 & 0.395 & 0.344 & 0.309 \\
\hline Corque & 0.373 & 0.226 & 0.274 & 0.183 & Toro Toro & 0.341 & 0.320 & 0.342 & 0.313 \\
\hline Choque Cota & 0.384 & 0.408 & 0.235 & 0.241 & Cotagaita & 0.476 & 0.527 & 0.434 & 0.299 \\
\hline Curahuara de & \multirow{2}{*}{0.334} & \multirow{2}{*}{0.459} & \multirow{2}{*}{0.314} & \multirow{2}{*}{0.267} & Vitichi & 0.500 & 0.461 & 0.411 & 0.359 \\
\hline Carangas & & & & & Sacaca & 0.280 & 0.328 & 0.293 & 0.234 \\
\hline Turco & 0.571 & 0.339 & 0.392 & 0.377 & Caripuyo & 0.411 & 0.437 & 0.447 & 0.370 \\
\hline Huachacalla & 0.387 & 0.421 & 0.313 & 0.306 & Tupiza & 0.613 & 0.650 & 0.527 & 0.429 \\
\hline Escara & 0.340 & 0.116 & 0.038 & 0.148 & Atocha & 0.550 & 0.666 & 0.517 & 0.452 \\
\hline Cruz de & \multirow{2}{*}{0.177} & \multirow{2}{*}{0.156} & \multirow{2}{*}{0.177} & \multirow{2}{*}{0.194} & Colcha "K" & 0.518 & 0.449 & 0.413 & 0.329 \\
\hline Machacamarca & & & & & San Pedro de & 0.207 & 0.257 & 0.230 & 0.251 \\
\hline Yunguyo de & \multirow{2}{*}{0.000} & \multirow{2}{*}{0.078} & \multirow{2}{*}{0.128} & \multirow{2}{*}{0.000} & Quemes & 0.207 & $0.25 \%$ & 0.230 & \\
\hline Litoral & & & & & San Pablo de & 0.625 & 0.653 & 0.564 & 0.416 \\
\hline $\begin{array}{l}\text { Esmeralda } \\
\text { Poopó }\end{array}$ & 0.004 & 0.000 & 0.167 & 0.029 & Lipez & 0.020 & 0.000 & & 0.431 \\
\hline $\begin{array}{l}\text { Poopó } \\
\text { Pazña }\end{array}$ & $\begin{array}{l}0.432 \\
0.615\end{array}$ & $\begin{array}{l}0.365 \\
0.545\end{array}$ & $\begin{array}{l}0.406 \\
0.582\end{array}$ & $\begin{array}{l}0.289 \\
0.472\end{array}$ & $\begin{array}{l}\text { Mojinete } \\
\text { San Antonio }\end{array}$ & 0.515 & 0.470 & 0.431 & \\
\hline Antequera & 0.446 & 0.382 & 0.518 & 0.386 & de Esmoruco & 0.444 & 0.476 & 0.442 & 0.269 \\
\hline Huanuni & 0.471 & 0.540 & 0.518 & 0.385 & Puna & 0.430 & 0.493 & 0.421 & 0.315 \\
\hline Machacamarca & 0.448 & 0.403 & 0.413 & 0.353 & Caiza "D" & 0.524 & 0.561 & 0.424 & 0.323 \\
\hline Salinas G. de & \multirow{2}{*}{0.272} & 328 & 0249 & 0057 & Uyuni & 0.581 & 0.703 & 0.589 & 0.492 \\
\hline Mendoza & & 328 & 0.249 & 0.057 & Tomave & 0.510 & 0.561 & 0.465 & 0.349 \\
\hline Pampa & 0216 & 261 & 0185 & 0105 & Porco & 0.475 & 0.595 & 0.540 & 0.394 \\
\hline Aullagas & 0.216 & .261 & 0.185 & 0.105 & Arampampa & 0.991 & 0.647 & 0.572 & 0.420 \\
\hline Sabaya & 0.170 & 0.092 & 0.123 & 0.122 & Acasio & 0.641 & 0.556 & 0.623 & 0.519 \\
\hline Coipasa & 0.379 & 0.387 & 0.286 & 0.337 & Llica & 0.469 & 0.529 & 0.488 & 0.372 \\
\hline Chipaya & 0.262 & 0.228 & 0.207 & 0.094 & Tahua & 0.271 & 0.298 & 0.310 & 0.218 \\
\hline Toledo & 0.225 & 0.225 & 0.125 & 0.106 & Villazón & 0.423 & 0.464 & 0.539 & 0.382 \\
\hline Eucaliptus & 0.530 & 0.524 & 0.404 & 0.424 & San Agustín & 0.549 & 0.612 & 0.529 & 0.356 \\
\hline Andamarca & 0.465 & 0.386 & 0.340 & 0.266 & Tarija & 0.576 & 0.656 & 0.539 & 0.427 \\
\hline Belén de & 0.325 & 0288 & & 0101 & Padcaya & 0.478 & 0.559 & 0.530 & 0.440 \\
\hline Andamarca & 0.325 & 0.288 & 0.172 & 0.101 & Bermejo & 0.499 & 0.480 & 0.460 & 0.399 \\
\hline Totora & 0.435 & 0.443 & 0.301 & 0.271 & Yacuiba & 0.468 & 0.465 & 0.453 & 0.415 \\
\hline
\end{tabular}




\begin{tabular}{|c|c|c|c|c|c|c|c|c|c|}
\hline Carapari & 0.500 & 0.646 & 1.000 & 1.000 & Concepción & 0.482 & 0.544 & 0.503 & 0.395 \\
\hline Villamontes & 0.550 & 0.666 & 0.647 & 0.552 & San Javier & 0.537 & 0.572 & 0.467 & 0.429 \\
\hline Uriondo & 0.409 & 0.387 & 0.357 & 0.339 & San Ramon & 0.414 & 0.645 & 0.437 & 0.353 \\
\hline Yunchara & 0.430 & 1.000 & 0.567 & 0.554 & San Julián & 0.490 & 0.471 & 0.554 & 0.401 \\
\hline San Lorenzo & 0.405 & 0.450 & 0.603 & 0.400 & & & & & \\
\hline \multirow{2}{*}{ Municipality } & WBI & WBI & WBI & WBI & \multirow{2}{*}{ Municipality } & WBI & WBI & WBI & WBI \\
\hline & 2002 & 2003 & 2006 & 2007 & & 2002 & 2003 & 2006 & 2007 \\
\hline El Puente & 0.428 & 0.514 & 0.582 & 0.386 & Cuatro & \multirow{2}{*}{0.392} & \multirow{2}{*}{0.363} & \multirow{2}{*}{0.428} & \multirow{2}{*}{0.298} \\
\hline Entre Ríos & 0.466 & 0.513 & 0.488 & 0.459 & Canadas & & & & \\
\hline Santa Cruz de & 0.551 & 0.624 & 0.486 & 0.379 & San Matías & 0.556 & 0.528 & 0.488 & 0.414 \\
\hline la Sierra & 0.551 & 0.624 & 0.486 & 0.379 & Comarapa & 0.532 & 0.536 & 0.547 & 0.462 \\
\hline Cotoca & 0.525 & 0.618 & 0.486 & 0.441 & Saipina & 0.508 & 0.599 & 0.558 & 0.448 \\
\hline Ayacucho & 0.455 & 0.462 & 0.373 & 0.298 & Puerto Suarez & 0.658 & 0.684 & 0.609 & 0.475 \\
\hline La Guardia & 0.500 & 0.572 & 0.486 & 0.381 & Puerto & \multirow{2}{*}{0.548} & \multirow{2}{*}{0.550} & \multirow{2}{*}{0.422} & \multirow{2}{*}{0.415} \\
\hline El Torno & 0.519 & 0.529 & 0.483 & 0.369 & Quijarro & & & & \\
\hline Warnes & 0.520 & 0.536 & 0.540 & 0.394 & Carmen Rivero & \multirow{2}{*}{0.478} & \multirow{2}{*}{0.502} & \multirow{2}{*}{0.526} & \multirow{2}{*}{0.427} \\
\hline Okinawa 1 & 0.387 & 0.548 & 0.462 & 0.343 & Torres & & & & \\
\hline San Ignacio & 0.509 & 0.562 & 0.539 & 0.411 & Ascención de & \multirow{2}{*}{0.523} & \multirow{2}{*}{0.509} & \multirow{2}{*}{0.551} & \multirow{2}{*}{0.425} \\
\hline San Miguel & 0.523 & 0.528 & 0.555 & 0.499 & Guarayos & & & & \\
\hline San Rafael & 0.348 & 0.454 & 0.379 & 0.270 & Urubicha & 0.488 & 0.495 & 0.561 & 0.441 \\
\hline Buena Vista & 0.492 & 0.535 & 0.470 & 0.421 & El Puente & 0.393 & 0.387 & 0.435 & 0.328 \\
\hline San Carlos & 0.582 & 0.647 & 0.554 & 0.456 & Trinidad & 0.592 & 0.693 & 0.530 & 0.492 \\
\hline Yapacaní & 0.490 & 0.573 & 0.488 & 0.412 & San Javier & 0.519 & 0.454 & 0.459 & 0.417 \\
\hline San Juan & 0.408 & 0.431 & 0.416 & 0.338 & Riberalta & 0.660 & 0.680 & 0.532 & 0.353 \\
\hline San José & 0.543 & 0.559 & 0.566 & 0.433 & Guayaramerín & 0.545 & 0.554 & 0.507 & 0.380 \\
\hline Pailón & 0.341 & 0.366 & 0.291 & 0.232 & Reyes & 0.551 & 0.437 & 0.388 & 0.311 \\
\hline Roboré & 0.616 & 0.600 & 0.593 & 0.582 & San Borja & 0.380 & 0.368 & 0.394 & 0.321 \\
\hline Portachuelo & 0.536 & 0.660 & 0.603 & 0.494 & Santa Rosa & 0.419 & 0.392 & 0.411 & 0.299 \\
\hline Santa Rosa del & 0470 & 0553 & 052 & 03 & Rurrenabaque & 0.499 & 0.613 & 0.457 & 0.366 \\
\hline Sara & & & & & Santa Ana & 0.592 & 0.704 & 0.550 & 0.485 \\
\hline Colpa Belgica & 0.332 & 0.322 & 0.309 & 0.285 & Exaltación & 0.229 & 0.219 & 0.157 & 0.126 \\
\hline Lagunillas & 0.366 & 0.394 & 0.384 & 0.341 & San Ignacio & 0.409 & 0.490 & 0.443 & 0.337 \\
\hline Charagua & 0.570 & 0.450 & 0.502 & 0.408 & Loreto & 0.459 & 0.429 & 0.435 & 0.287 \\
\hline Cabezas & 0.356 & 0.343 & 0.292 & 0.287 & San Andrés & 0.401 & 0.434 & 0.436 & 0.436 \\
\hline Cuevo & 0.566 & 0.684 & 0.534 & 0.471 & San Joaquín & 0.578 & 0.622 & 0.514 & 0.471 \\
\hline Gutierrez & 0.519 & 0.555 & 0.551 & 0.421 & San Ramón & 0.593 & 0.528 & 0.596 & 0.396 \\
\hline Camiri & 0.614 & 0.788 & 0.747 & 0.500 & Puerto Siles & 0.517 & 0.532 & 0.512 & 0.485 \\
\hline Boyuibe & 0.486 & 0.527 & 0.528 & 0.363 & Magdalena & 0.541 & 0.640 & 0.577 & 0.516 \\
\hline Valle Grande & 0.647 & 0.702 & 0.504 & 0.458 & Baures & 0.507 & 0.600 & 0.550 & 0.454 \\
\hline El Trigal & 0.544 & 0.594 & 0.411 & 0.204 & Huacaraje & 0.542 & 0.601 & 0.561 & 0.428 \\
\hline Moro Moro & 0.493 & 0.498 & 0.388 & 0.412 & Cobija & 0.554 & 0.726 & 0.652 & 0.464 \\
\hline Postrer Valle & 0.460 & 0.427 & 0.350 & 0.238 & Porvenir & 0.386 & 0.394 & 0.260 & 0.328 \\
\hline Pucara & 0.522 & 0.493 & 0.418 & 0.371 & Bolpebra & 0.401 & 0.238 & 0.554 & 0.484 \\
\hline Samaipata & 0.570 & 0.608 & 0.487 & 0.450 & Bella Flor & 0.112 & 0.250 & 0.668 & 0.251 \\
\hline Pampa Grande & 0.525 & 0.511 & 0.502 & 0.316 & Puerto Rico & 0.508 & 0.487 & 0.663 & 0.535 \\
\hline Mairana & 0.626 & 0.576 & 0.619 & 0.523 & San Pablo (San & & & & \\
\hline Quirusillas & 0.362 & 0.348 & 0.324 & 0.271 & Pedro) & 0.708 & 0.762 & 0.528 & 0.460 \\
\hline Montero & 0.566 & 0.603 & 0.538 & 0.457 & Filadelfia & 0.312 & 0.197 & 0.488 & 0.280 \\
\hline Gral. Saavedra & 0.426 & 0.508 & 0.353 & 0.322 & Puerto & & & & \\
\hline Mineros & 0.513 & 0.672 & 0.434 & 0.341 & Gonzalo & 0.391 & 0.511 & 0.386 & 0.385 \\
\hline Fernandez & 395 & & & 3 & Moreno & & & & \\
\hline Alonso & 0.395 & 0.398 & 0.448 & 0.31 & San Lorenzo & 0.588 & 0.498 & 0.703 & 0.380 \\
\hline San Pedro & 0.425 & 0.475 & 0.515 & 0.383 & Sena & 0.464 & 0.297 & 0.699 & 0.538 \\
\hline
\end{tabular}




\begin{tabular}{lcccc}
$\begin{array}{l}\text { Nacebe (Santa } \\
\text { Rosa de } \\
\text { Abuna) }\end{array}$ & 0.277 & 0.311 & 0.459 & 0.450 \\
$\begin{array}{l}\text { Ingavi } \\
\text { Nuevo Manoa } \\
\text { (Nueva }\end{array}$ & 0.004 & 0.263 & 0.163 & 0.245 \\
$\begin{array}{l}\text { Esperanza } \\
\text { Villa Nueva }\end{array}$ & 0.311 & 0.247 & 0.281 & 0.071 \\
$\begin{array}{l}\text { Eureka (Santos } \\
\text { Mercado) }\end{array}$ & 0.082 & 0.187 & 0.277 & 0.196 \\
\hline
\end{tabular}


